\title{
48. LITHOLOGY OF MESOZOIC AND CENOZOIC SEDIMENTS OF THE EASTERN INDIAN OCEAN, LEG 27, DEEP SEA DRILLING PROJECT
}

\author{
Paul T. Robinson, Department of Earth Sciences, \\ University of California, Riverside, California \\ Paul A. Thayer, Program of Marine Sciences Research, \\ University of North Carolina, Wilmington, North Carolina \\ Peter J. Cook, Bureau of Mineral Resources, \\ Geology and Geophysics, Canberra, Australia \\ and \\ Brian K. McKnight, Department of Geology, \\ University of Wisconsin, Oshkosh, Wisconsin
}

\begin{abstract}
During Leg 27 five sites were drilled in the eastern Indian Ocean-four in abyssal plains near the western margin of Australia and one in the Timor Trough. Abyssal plain sediments are divided into two major units: (1) a lower, acoustically transparent layer of relatively uniform thickness draped over basaltic basement and (2) a horizontally layered sequence of highly variable thickness filling low areas on the surface of the transparent layer. The transparent layer, ranging in age from Upper Jurassic to Upper Cretaceous, consists chiefly of dark gray, siliceous clays and claystones with minor zeolitic clay and nannofossil ooze. Sedimentation rates are between 5 and $30 \mathrm{~m} / \mathrm{m} . \mathrm{y}$. being highest in the Lower Cretaceous. Upper Cretaceous sediment are sparse or absent. The relatively high sedimentation rates for pelagic clay are probably due to the proximity of the Australian continent. The layered unit consists of calcareous oozes and lesser zeolitic clay and radiolarian ooze, all of Cenozoic age. Many of the oozes contain shallow-water foraminifers and graded sequences suggesting deposition by mass transport. Calculated sedimentation rates for the upper Cenozoic range from 5 to $15 \mathrm{~m} / \mathrm{m} . \mathrm{y}$. Very few lower Tertiary sediments were recovered because drilling sites were selected near crests of highs in the transparent layer where Cenozoic sediments are thin. The great influx of carbonate ooze in the Cenozoic is probably related to changes in climate and oceanic circulation associated with the separation of Australia and Antarctica in the Eocene.

In the Timor Trough approximately 400 meters of nannofossil and foraminiferal ooze containing abundant reworked fossils and graded sequences unconformably overlie shallow-water dolomitic limestone and dolomitic calcarenite of middle to lower Pliocene age. Accumulation rates are roughly $185 \mathrm{~m} / \mathrm{m} . \mathrm{y}$. in the Quaternary and $25 \mathrm{~m} / \mathrm{m} . \mathrm{y}$. in the upper Pliocene. The rapid sedimentation rates are presumably due to high pelagic production and to introduction of sediment from the flanks of the trough. The trough apparently formed in middle Pliocene and has undergone relatively little deformation since.
\end{abstract}

\section{INTRODUCTION}

During Leg 27 of the Deep Sea Drilling Project, abyssal sediments were drilled at four sites in the eastern Indian Ocean (Figure 1). These four sites, 259, 260, 261, and 263, all lie off the west coast of Australia and are located in the Perth, Argo, Gascoyne, and Cuvier abyssal plains, respectively. One site, 262 , was drilled in shallow water near the axis of the Timor Trough (Figure 1).
At the four abyssal plain sites seismic profiling indicates a broad twofold division in the sediments overlying acoustic basement: (1) a lower sequence of acoustically transparent sediments draped conformably over basement and (2) a sequence of flat-lying acoustically layered sediments that unconformably overlies the transparent unit. At several sites a thin, acoustically transparent layer occurs at the top of the layered unit at the sea floor. These relationships are well illustrated in the seismic profile at Site 260 (Figure 2). 


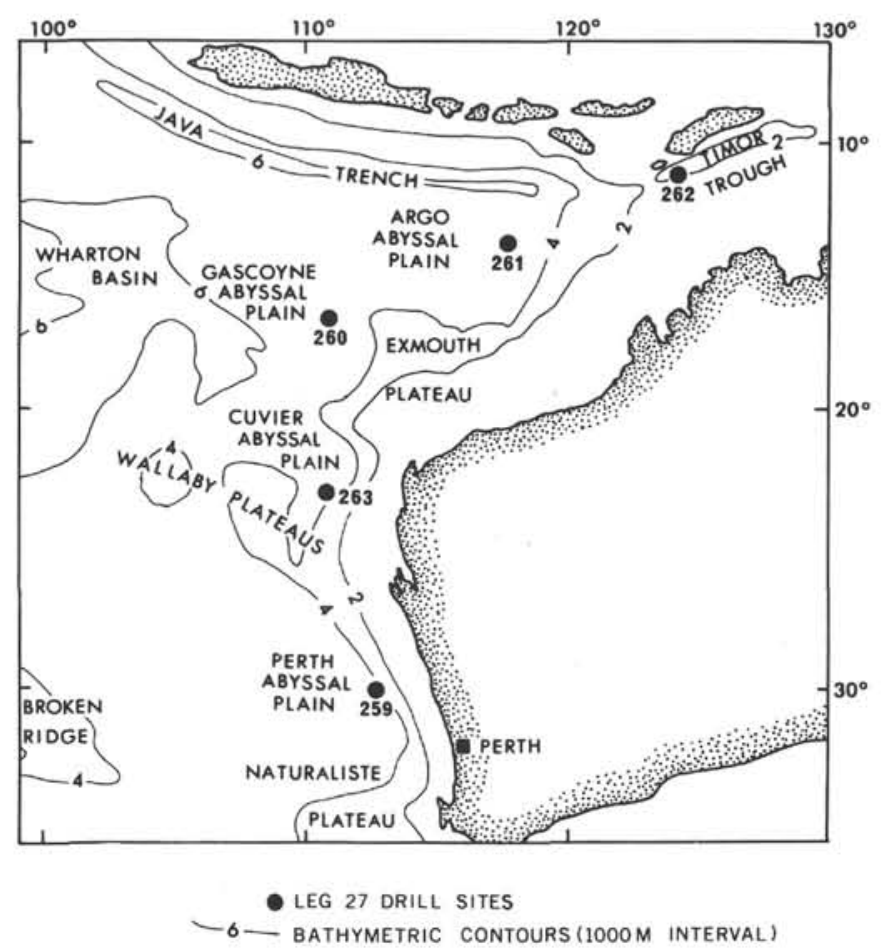

Figure 1. Location of sites drilled during Leg 27.

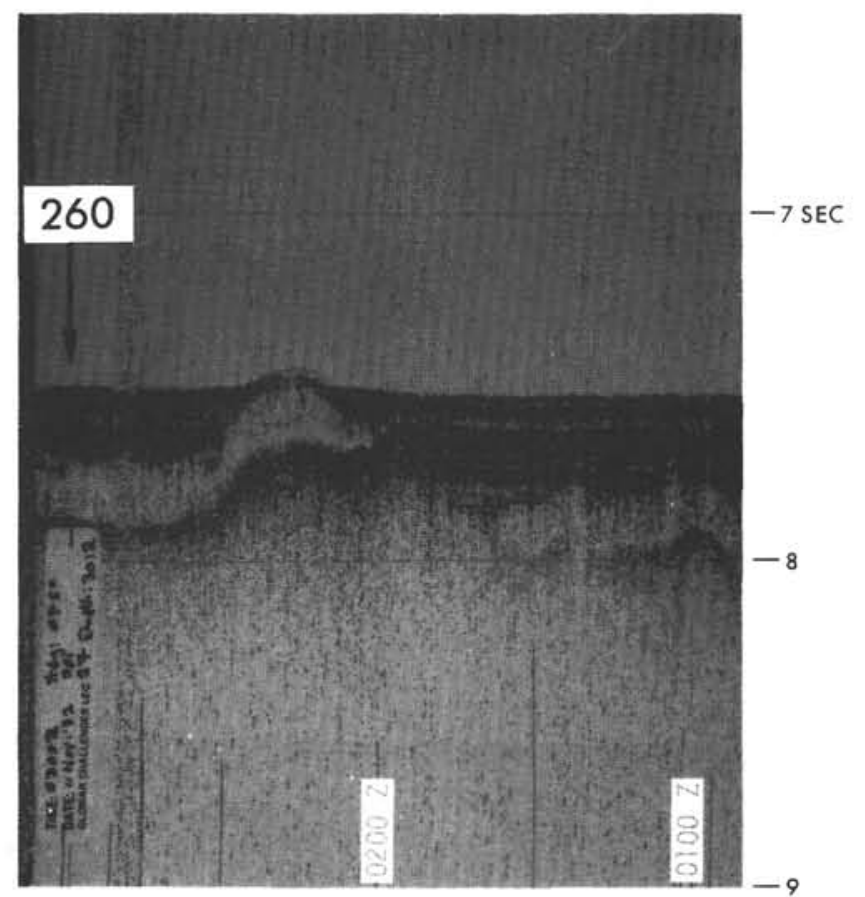

Figure 2. Seismic profile in vicinity of Site 260. A flat-lying sequence of acoustically layered sediments unconformably overlies an acoustically transparent sedimentary sequence draped over basaltic basement.
Generally, the drilling sites were selected near crests of highs in the transparent unit where the layered sequence is thin. Study of cores recovered from these sites reveals that the transparent sequence consists chiefly of brown to dark greenish-gray clay and claystone with lesser quantities of nannofossil ooze and nannofossil-rich clay. Usually these sediments are well indurated, noncalcareous, and poorly bedded. The acoustically layered sequence consists predominantly of light-colored, poorly indurated nannofossil and foraminiferal nannofossil ooze often containing graded sequences indicative of mass transport. Subordinate amounts of brown, zeolitic clay are also present.

At Sites 260 and 263 the contact between the layered and transparent sequences lies at the CretaceousTertiary boundary (Figure 3). At Site 259 seismic profiles show only a single strong reflector that corresponds to basaltic basement. However, the sedimentbasement contact is steep near this site, and side reflectors from the basement prevented the recording of other possible reflectors in the sediment column. The lithologic break at the Cretaceous-Tertiary boundary is similar to that at Sites 260 and 263, and presumably this contact would show a strong reflection under normal conditions. At Site 261 the seismic boundary between the transparent and layered sequences was computed to lie at a depth of 142 meters in an interval where no cores were taken. The observed Cretaceous-Tertiary boundary occurs at a depth of 170 meters where it corresponds to a sharp lithologic break. However, the highly brecciated nature of the Tertiary sediments in this core and their presence well below the strong reflector at 142 meters suggest that they are displaced from above. Hence, by comparison with adjacent sites, the Cretaceous-Tertiary boundary at Site 261 is interpreted to correspond with the strong reflector at 142 meters.

The Cretaceous-Tertiary unconformity observed on Leg 27 has also been reported on the Naturaliste Plateau (DSDP Site 258), on Broken Ridge (DSDP Site 255), and in the Wharton Basin (DSDP Site 212) (Luyendyk et al., 1973; von der Borch, Sclater, et al., 1974) indicating that it is of regional extent. In general, the twofold subdivision of the deep-sea sediments recognized on Leg 27 appears to be characteristic of the entire eastern Indian Ocean. However, the Mesozoic sediments below the unconformity thin rapidly westward and apparently pinch out just east of the Ninetyeast Ridge between ZSDP Sites 211 and 213 (von der Borch, Sclater, et al., 1974).

Site 262, located in 2315 meters of water near the axis of the Timor Trough, lies in an entirely different structural and depositional environment (Figure 1). Situated immediately south of Timor, the trough is believed to have developed along the leading edge of the Australian plate in response to resistance to northward underthrusting (Veevers et al., in press). Seismic profiles perpendicular to the trough axis reveal flat-lying beds unconformably overlying north-dipping reflectors traceable from the north Australian shelf (Veevers et al., in press; Beck and Lehner, 1974). Drilling at this site revealed a complete sequence of Pliocene to Recent calcareous oozes overlying a shallow-water dolomitic shell 


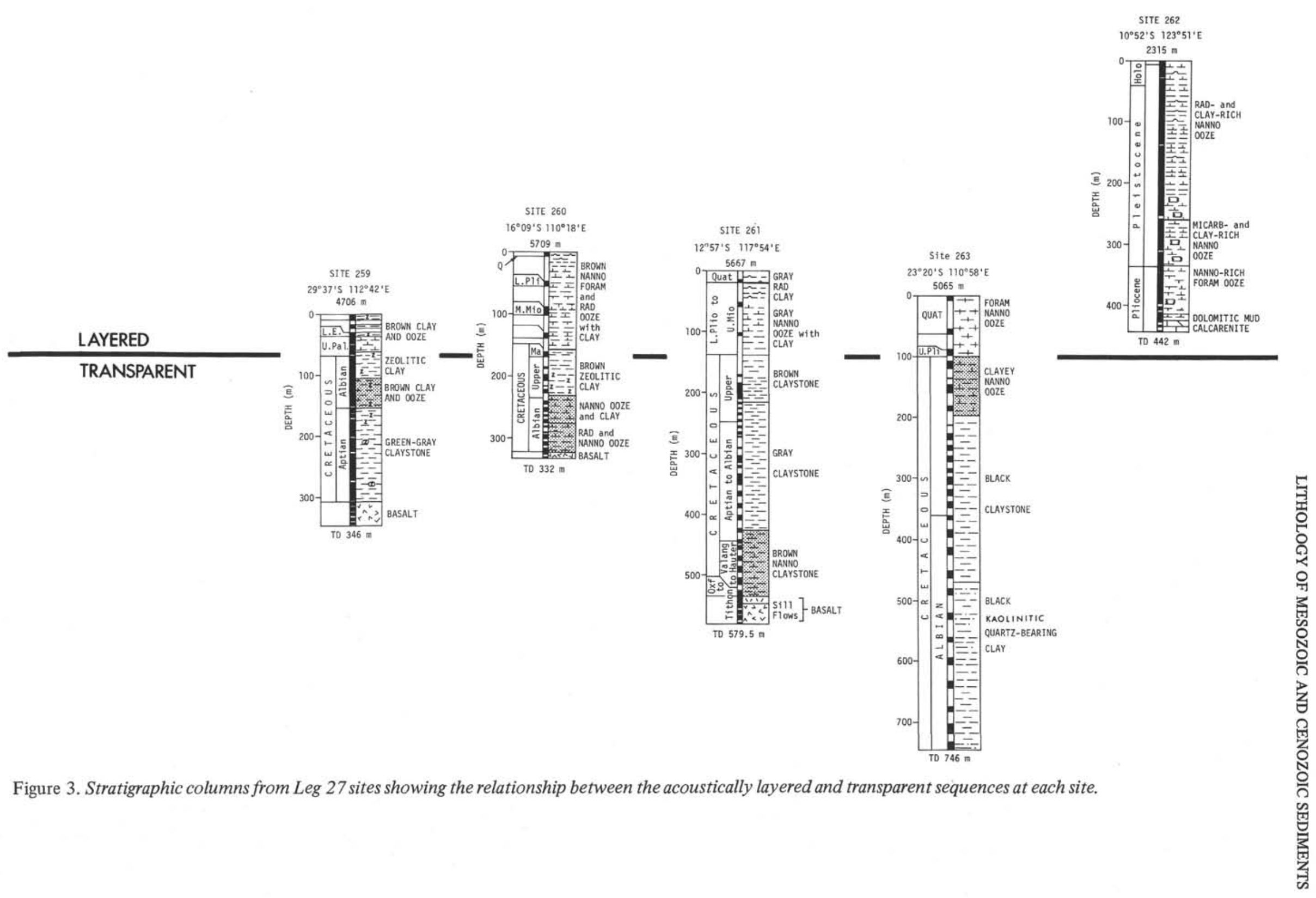


calcarenite of Pliocene age. Based on these relationships, the Timor Trough is believed to have developed in middle Pliocene and to have been the site of rapid sedimentation during late Pliocene and Quaternary time.

\section{LITHOLOGY}

\section{Mesozoic Abyssal Plain Sediments}

Mesozoic sediments are chiefly dark greenish-gray, siliceous clays and claystones with subordinate zeolite clay and nannofossil clay and ooze. In general, the lighter-colored oozes and zeolitic clays occur near the top of the transparent sequence. At Sites 261 and 263, however, small quantities of nannofossil ooze occur at the base of the sequence (Figure 3).

\section{Siliceous Clays and Claystones}

Siliceous clays and claystones, defined as those containing microcrystalline and cryptocrystalline quartz and cristobalite, make up the bulk of the transparent unit, accounting for roughly $70 \%$ of the Mesozoic section drilled. These sediments are abundant at all abyssal plain sites except Site 260 . Here drilling terminated in a basalt sill that probably lies well above oceanic basement. Hence, it is possible that siliceous clays, which normally are most common in the lower part of the section, are present below the sill.

The siliceous clays and claystones are chiefly dark gray or greenish-gray to olive-black in color, more rarely reddish-brown to moderate yellowish-brown. The lighter colors occur most frequently at the top of the transparent unit. Most of these sediments are mod-

TABLE 1

Summary of Lithologic features of Mesozoic Abyssal Plan Sediments of the Eastern Indian Ocean

\begin{tabular}{|c|c|c|c|}
\hline Unit & $\begin{array}{l}\text { Siliceous Clays } \\
\text { and Claystones }\end{array}$ & Zeolitic Clays & Nanno Oozes and Clays \\
\hline Distribution & $\begin{array}{l}\text { Site } 259 \text {, Cores } 18-33 \\
\text { Site } 261 \text {, Cores 6-12, 19-29 } \\
\text { Site 263, Cores 4-29 }\end{array}$ & $\begin{array}{l}\text { Site } 259 \text {, Cores } 8-11,17,18 \\
\text { Site } 260 \text {, Cores } 6-8,12 \\
\text { Site } 261 \text {, Cores } 8,9\end{array}$ & $\begin{array}{l}\text { Site } 259, \text { Cores } 12-17 \\
\text { Site } 260 \text {, Cores } 9-18 \\
\text { Site } 261 \text {, Cores 5, 30-33 }\end{array}$ \\
\hline Thickness (m) & 330 & 55 & 63 \\
\hline Induration & $\begin{array}{l}\text { Mostly indurated, some } \\
\text { stiff to semilithified }\end{array}$ & Stiff & Stiff to semilithified \\
\hline Color & $\begin{array}{l}\text { Chiefly dark gray, olive- } \\
\text { black, and greenish- } \\
\text { black; some reddish- to } \\
\text { yellowish-brown }\end{array}$ & $\begin{array}{l}\text { Dark yellowish-brown to } \\
\text { moderate brown }\end{array}$ & $\begin{array}{l}\text { Oozes moderate brown to } \\
\text { yellowish-brown; clays } \\
\text { grayish-green and dusky } \\
\text { yellow-green }\end{array}$ \\
\hline $\begin{array}{l}\text { Primary } \\
\text { Structures }\end{array}$ & $\begin{array}{l}\text { Chiefly thinly lamin- } \\
\text { ated, laminae both } \\
\text { regular and irregular; } \\
\text { often mottled }\end{array}$ & $\begin{array}{l}\text { Thin bedded, irregularly } \\
\text { laminated and broadly } \\
\text { color banded }\end{array}$ & $\begin{array}{l}\text { Thinly bedded and laminated; } \\
\text { lenticular laminae and rare } \\
\text { cross-laminae; color mottled }\end{array}$ \\
\hline $\begin{array}{l}\text { Secondary } \\
\text { Structures }\end{array}$ & $\begin{array}{l}\text { Often parted; abundant } \\
\text { dolomite nodules, some } \\
\text { calcite, barite, and } \\
\text { siderite nodules }\end{array}$ & Some dolomite nodules & $\begin{array}{l}\text { Slight parting; few dolomite } \\
\text { nodules }\end{array}$ \\
\hline $\begin{array}{l}\text { Mean Grain } \\
\text { Size }(\phi)\end{array}$ & 10.5 & 10.1 & 10.2 \\
\hline Sorting $(\phi)$ & 2.5 & 2.75 & 2.75 \\
\hline $\begin{array}{l}\text { Sand:Silt: } \\
\text { Clay Ratio (\%) }\end{array}$ & $1: 19: 80$ & $1: 24: 75$ & $1: 25: 74$ \\
\hline $\begin{array}{l}\text { Chief } \\
\text { Constituents }\end{array}$ & $\begin{array}{l}\text { Montmorillonite, } \\
\text { cristobalite, quartz, } \\
\text { and mica }\end{array}$ & $\begin{array}{l}\text { Palygorskite, mica, } \\
\text { montmorillonite, and } \\
\text { clinoptilolite }\end{array}$ & $\begin{array}{l}\text { Calcite (nanno fossils), quartz, } \\
\text { cristobalite, and } \\
\text { montmorillonite }\end{array}$ \\
\hline $\begin{array}{l}\text { Organic } \\
\text { Carbon }(\%)\end{array}$ & 0.5 & 0.1 & 0.1 \\
\hline $\begin{array}{l}\text { Carbonate } \\
\text { Carbon }(\%)\end{array}$ & $0-5$ & $0-4$ & $10-58$, average 35 \\
\hline $\begin{array}{l}\text { Diagenetic } \\
\text { Minerals }\end{array}$ & $\begin{array}{l}\text { Dolomite, gypsum, } \\
\text { cristobalite, micro- } \\
\text { crystalline quartz, and } \\
\text { pyrite }\end{array}$ & $\begin{array}{l}\text { Palygorskite (?), zeolite, } \\
\text { chalcedony, and pyrite }\end{array}$ & $\begin{array}{l}\text { Dolomite, zeolite, } \\
\text { cristobalite, and pyrite }\end{array}$ \\
\hline
\end{tabular}


erately to well indurated; some are lithified. The degree of induration generally increases with depth at any given site and correlates directly with the percent of microcrystalline quartz and cristobalite in the sediment.

Typically, the clays and claystones are thinly laminated with individual layers ranging from 0.3 to $1 \mathrm{~cm}$ in thickness. Laminae may be either regular (continuous across the core) or irregular; many irregular laminae are lenticular, possibly reflecting minor irregularities on the original depositional surface. The laminae are usually dark gray to olive-black against a medium gray background, and may represent organic-rich layers. Other laminae are slightly calcareous (Plate 1, Figure 1) or slightly silty. Many cores also have distinct color mottling, again chiefly dark gray or olive-black against a lighter gray background. Most mottles range from 0.5 to $1 \mathrm{~cm}$ across and typically have sharp, distinct boundaries. Some of the color mottles probably represent infilled burrows (van der Lingen, 1973), but the preservation of laminae throughout these sediments suggests that burrowing activity was low. A few mottles are lighter colored and more calcareous than the background and may be incipient carbonate concretions Mlate 11, Figure 1). In thin section the clays are typically structureless to faintly layered (Plate 2, Figures 1, 2, and 3); a few have nodular bedding (Plate 2, Figure 4).

Texturally, these sediments are very poorly sorted clays and silty clays with an average grain size of $10.5 \phi$ (Figure 4). Small quantities of clayey silt and sandy clay are present near the base of the section at Site 263. The silt component consists chiefly of angular quartz grains (Plate 1, Figure 6; Plate 2, Figure 4).

Based on X-ray diffraction data, montmorillonite and mica combined make up approximately $50 \%$ of these sediments (Figures 5-7); the remainder consists chiefly of microcrystalline and cryptocrystalline quartz and cristobalite, and small quantities of feldspar, chlorite, and pyrite. Palygorskite is abundant at Site 261, Cores 6 through 9 (Figure 6), and kaolinite is very common in the lower part of the section at Site 263 (Figure 7). Trace amounts of nannofossils, radiolarians, fish remains, sponge spicules, glauconite, and heavy minerals are also present. Opaque minerals dominate the heavy mineral fraction, but small quantities of clinopyroxene, epidote, garnet, hornblende, zircon, and sphene are also present.

The siliceous clays and claystones have undergone extensive diagenesis including compaction, cementation, solution of calcareous and siliceous fossils, and formation of diagenetic minerals. The sediments owe their induration largely to compaction and cementation by microcrystalline and cryptocrystalline quartz and cristobalite. Nodules of dolomite, barite, calcite, and siderite are also common and widely distributed. These generally range from a few millimeters to $5 \mathrm{~cm}$ across. Some carbonate layers are also present but these may be part of large nodules (Plate 11, Figure 7). Dolomite makes up most of the nodules and also occurs as isolated rhombs in the clays (Plate 4, Figure 1). Pyrite is widespread and occurs as isolated crystals, as framboids, or, rarely, as rounded grains. Barite and pyrite often occur in

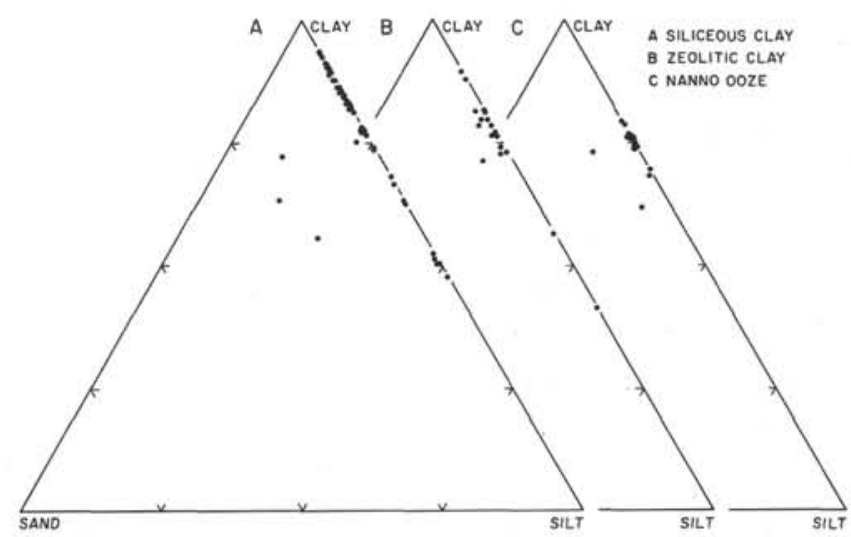

Figure 4. Texture of Mesozoic abyssal plain sediments of the eastern Indian Ocean.

TABLE 2

Average Chemical Analyses of Mesozoic Sediments of the Eastern Indian Ocean

\begin{tabular}{|c|c|c|c|c|c|}
\hline Element & $\begin{array}{c}\text { Zeolite } \\
\text { Clay }\end{array}$ & $\begin{array}{l}\text { Siliceous } \\
\text { Clay }\end{array}$ & $\begin{array}{c}\text { Radiolarian } \\
\text { Ooze }\end{array}$ & $\begin{array}{c}\text { Nanno } \\
\text { Ooze }\end{array}$ & $\begin{array}{c}\text { Nanno } \\
\text { Clay }\end{array}$ \\
\hline \multicolumn{6}{|l|}{ Major $^{a}$} \\
\hline $\mathrm{SiO}_{2}$ & 56.6 & 63.9 & 77.0 & 35.1 & 56.2 \\
\hline $\mathrm{TiO}_{2}$ & 0.62 & 0.54 & 0.26 & 0.27 & 0.60 \\
\hline $\mathrm{A}_{2}{ }_{2} \mathrm{O}_{3}$ & 11.7 & 11.1 & 4.5 & 5.9 & 12.9 \\
\hline $\mathrm{Fe}_{2} \mathrm{O}_{3}$ & 6.8 & 6.5 & 3.4 & 4.2 & 5.8 \\
\hline $\mathrm{MnO}$ & 0.41 & 0.25 & 0.32 & 0.38 & 0.05 \\
\hline $\mathrm{MgO}$ & 2.5 & 2.2 & 1.6 & 1.6 & 2.4 \\
\hline $\mathrm{CaO}$ & 2.1 & 1.6 & 1.8 & 24.0 & 3.7 \\
\hline $\mathrm{Na}_{2} \mathrm{O}$ & 3.0 & 1.9 & 2.0 & 1.9 & 2.3 \\
\hline $\mathrm{K}_{2} \mathrm{O}$ & 3.0 & 2.1 & 1.7 & 1.6 & 2.4 \\
\hline $\mathrm{P}_{2} \mathrm{O}_{5}$ & 0.13 & 0.16 & 0.08 & 0.05 & 0.14 \\
\hline $\mathrm{Cr}_{2} \mathrm{O}_{3}$ & $<0.1$ & $<0.1$ & $<0.1$ & $<0.1$ & $<0.1$ \\
\hline $\mathrm{V}_{2} \mathrm{O}_{5}$ & $<0.15$ & $<0.05$ & $<0.05$ & $<0.05$ & $<0.05$ \\
\hline LOI & 13.0 & 9.8 & 7.3 & 25.1 & 13.6 \\
\hline Total & 100.1 & 100.2 & 100.1 & 100.2 & 100.2 \\
\hline $\mathrm{CO}_{2}$ & 1.01 & 1.1 & 1.1 & 18.3 & 2.8 \\
\hline $\mathrm{H}_{2} \mathrm{O}$ & 11.5 & 8.2 & 6.2 & 5.7 & 10.9 \\
\hline \multicolumn{6}{|l|}{ Trace $^{b}$} \\
\hline $\mathrm{Sr}$ & 140 & 164 & 90 & 415 & 100 \\
\hline $\mathrm{Ba}$ & 950 & 936 & 250 & 543 & 200 \\
\hline $\mathrm{Li}$ & 30 & 44 & 50 & 22 & 40 \\
\hline $\mathrm{Cu}$ & 320 & 75 & 160 & 207 & 55 \\
\hline $\mathrm{Pb}$ & 16 & 26 & 1 & 12 & 17 \\
\hline $\mathrm{Zn}$ & 110 & 139 & 60 & 73 & 140 \\
\hline Co & 20 & 30 & 8 & 9 & 25 \\
\hline $\mathrm{Ni}$ & 70 & 55 & 30 & 61 & 30 \\
\hline
\end{tabular}

\footnotetext{
${ }^{\mathrm{a}}$ In percent.
}

in ppm. 


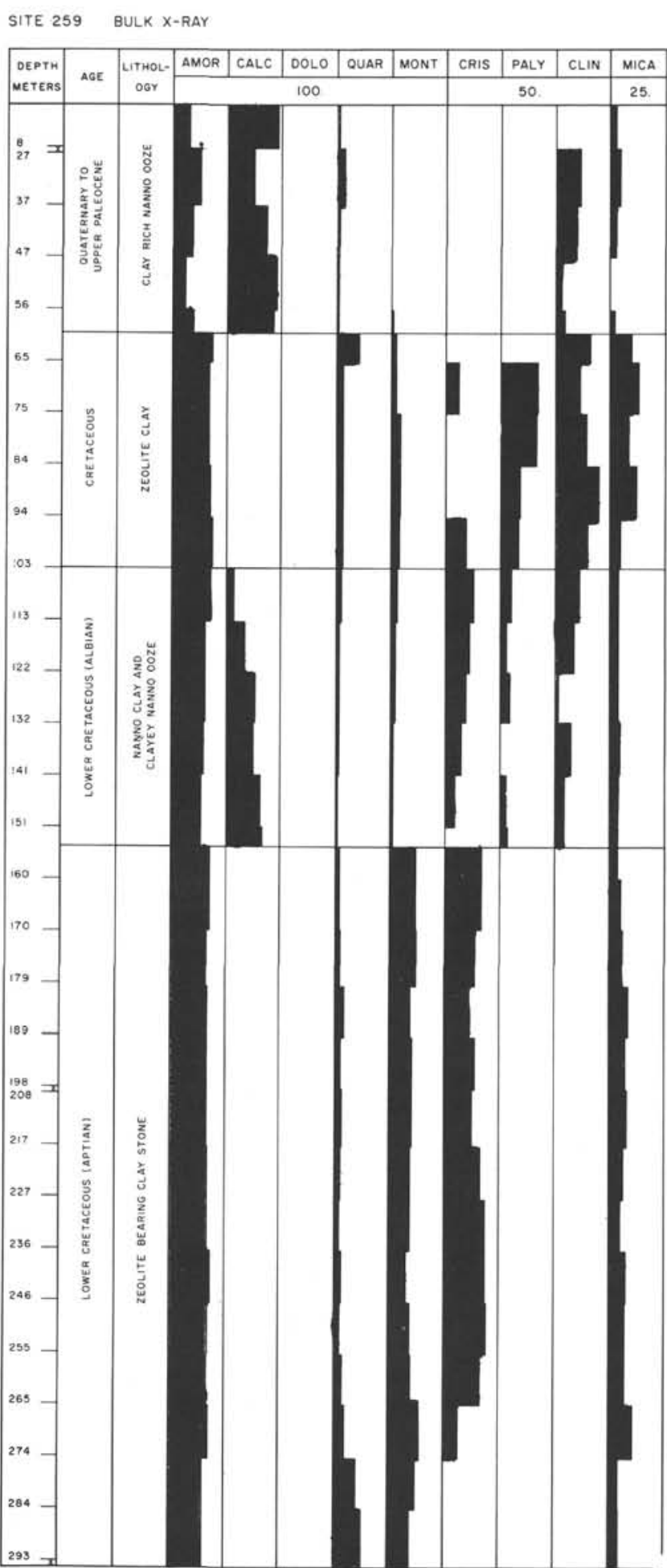

Figure 5. Distribution of minerals in sediments from Site 259 based on X-Ray diffraction analysis. Only minerals in excess of $10 \%$ are included.

proximity suggesting that chemical microenvironments controlled the diagenetic processes. Trace amounts of clinoptilolite are also present.

As expected, the chemical composition of the clays and claystones closely reflects their mineralogy. Com-

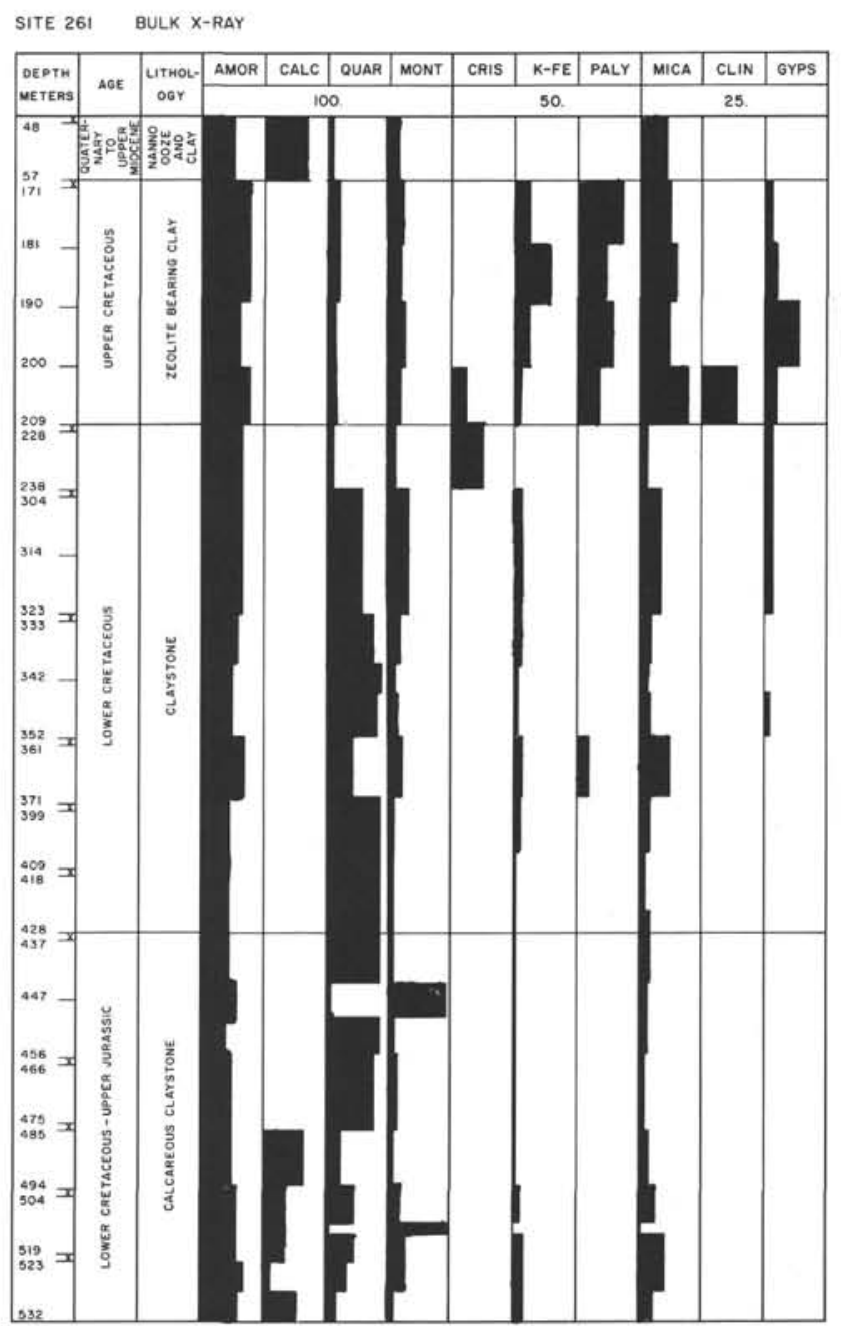

Figure 6. Distribution of minerals in sediments from Site 261 based on X-Ray diffraction analysis. Only minerals in excess of $10 \%$ are included.

pared to average shales (Pettijohn, 1957; Garrels and MacKenzie, 1971) these sediments are markedly enriched in $\mathrm{SiO}_{2}$ and relatively depleted in most other oxides (Table 2). Silica ranges from $47 \%$ to $81 \%$ and averages about $65 \%$.

Kaolinite-rich claystones are abundant in the basal sediments at Site 263 (Figure 7). These sediments are similar to the other siliceous claystones except that they are somewhat coarser grained, and kaolinite is more abundant than montmorillonite. Although kaolinite is present throughout the sediment, it is often concentrated in specks, wisps, and layers up to $20 \mathrm{~cm}$ thick (Figure 8). In these layers the kaolinite occurs as rounded to subrounded, sand-size pellets, often slightly ovate or flattened (Plate 4, Figures 4-6). The pellets may be either white or dark green and consist of a fine mosaic of curved kaolinite crystals (Plate 9, Figure 3) together with small grains of quartz and feldspar and small patches of dark organic(?) material. The pellets are well sorted and were deposited with an open framework which was later filled with calcite cement (Plate 4, 
SITE 263 BULK $X$-RAY

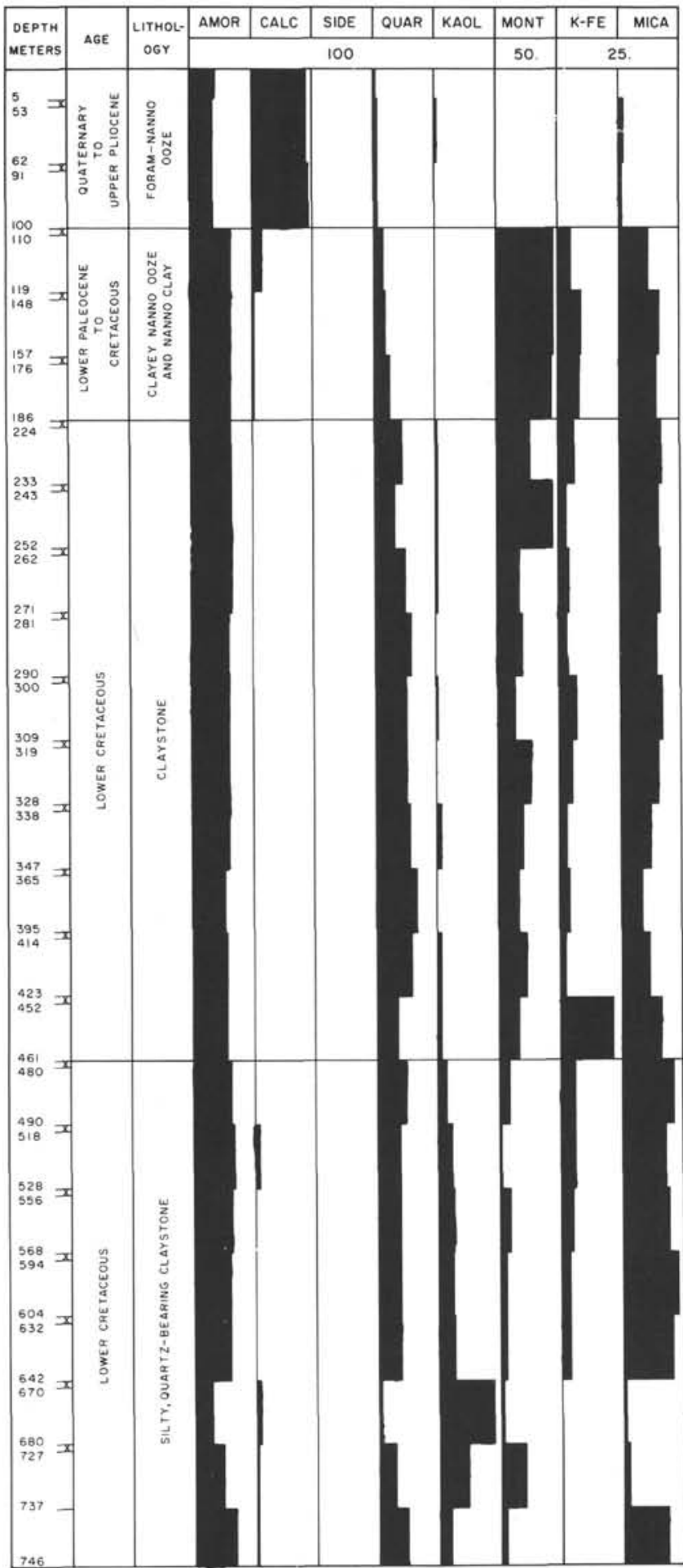

Figure 7. Distribution of minerals in sediments from Site 263 based on X-Ray diffraction analysis. Only minerals in excess of $10 \%$ are included.

Figures 5 and 6); some of the cement may possibly have replaced a clay matrix.

Oolitic and pisolitic textures such as these are common in kaolinitic clays and may represent either diagenetic alteration of preexisting pellets, such as glauconite, or reworking of kaolinitic muds (Carozzi, 1960). The lack of internal structure, the presence of quartz and feldspar grains of similar size, and the high degree of rounding and sorting of these pellets suggest a clastic origin.

\section{Zeolitic Clay}

Zeolitic clay, containing more than $10 \%$ clinoptilolite or phillipsite, makes up approximately $12 \%$ of the Mesozoic sediments and occur near the top of the transparent layer. These sediments are most abundant at Site 259 but small quantities are also present at Sites 260 and 261 (Figure 3).

In sharp contrast to the underlying siliceous clays, these sediments are brown to yellowish-brown or, rarely gray-green. Many show extensive streaking and color mottling due to drilling deformation, and a few have dark, distinct color mottles suggesting filled burrows (Plate 11, Figure 4). The zeolitic clays are typically thin bedded and either homogeneous (Plate 1, Figure 3) or irregularly laminated (Plate 1, Figure 1). They are typically stiff, very poorly sorted silty clays (Figure 4 ) in which the silt component is zeolite.

Palygorskite, clay minerals, and mica combined make up approximately $50 \%$ of these clays; the remainder consists chiefly of clinoptilolite and microcrystalline to cryptocrystalline quartz, and cristobalite (Figures 5, 6, and 9). Small quantities of $\mathrm{K}$-feldspar, plagioclase, and tridymite are also present. Clinoptilolite averages about $20 \%$ and occurs as scattered crystals and as clusters filling radiolarian molds (Plate 1, Figure 3 ). Other diagenetic minerals are pyrite and chalcedony (Plate 1 , Figure 4). Heavy minerals are similar to those in the siliceous clays and consist chiefly of opaque minerals with lesser amounts of clinopyroxene, orthopyroxene, epidote, hornblende, zircon, sphene, and tourmaline.

Except for being notably lower in silica and somewhat higher in alkalies, these sediments are chemically similar to the siliceous clays (Table 2).

\section{Nannofossil Ooze and Nannofossil-Rich Clay}

Calcareous sediments make up only about $14 \%$ of the transparent layer. They occur chiefly near the top of the Mesozoic sequence at Sites 259, 260, and 263 where they are associated with brown zeolitic clays (Figure 3 ). At Site 261, however, a 50-meter-thick layer of nannofossilrich clay occurs at the base of the section.

The calcareous sediments are chiefly nannofossil ooze with lesser amounts of clay-rich ooze and nannofossilrich clay. The oozes are moderate brown to yellowishbrown, grading into yellowish-green to grayish-green with increasing clay content. They often display color lamination, broad color banding, and color mottling (Plate 11, Figures 3, 5, and 6). The layers and laminae are either regular, irregular, or lenticular and result from alternating layers of ooze and clay. Irregular crosslaminae are sometimes present (Plate 11, Figures 5 and 8). Color mottles with sharp, distinct boundaries are probably burrows (Plate 11, Figure 3 ).

Both the oozes and clays are very poorly sorted and somewhat silty (Figure 4). Mean grain size is $10.2 \phi$ and 


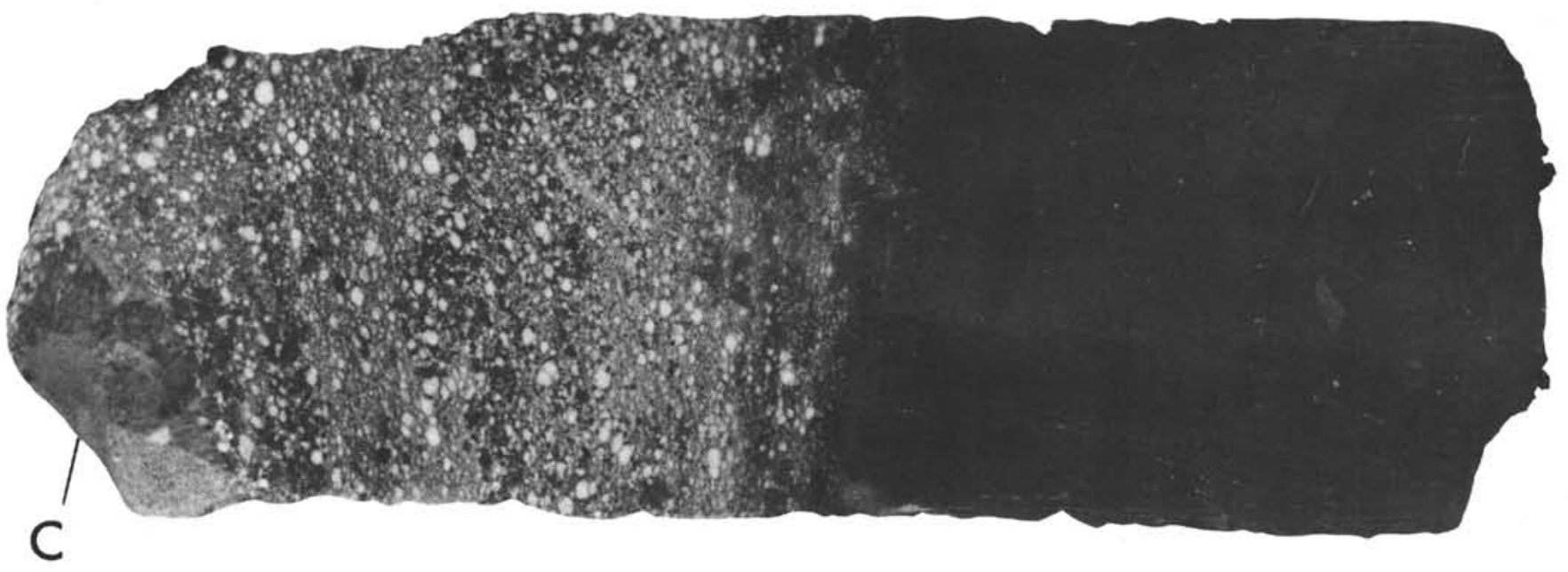

Figure 8. White kaolinite pellets in Mesozoic silty claystone of Site 263. Note the distribution and ovate shape of the pellets.

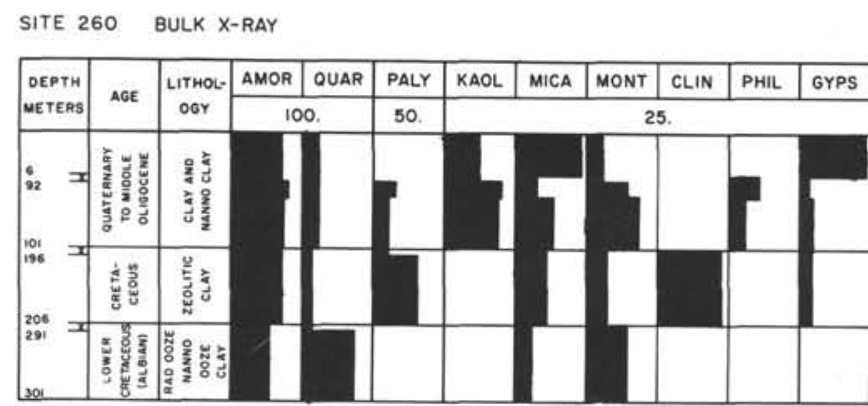

Figure 9. Distribution of minerals in sediments from Site 260 based on $X$-Ray diffraction analysis. Only minerals in excess of $10 \%$ are included.

average textural composition is $1 \%$ sand, $25 \%$ silt, and $74 \%$ clay. The silt component consists of zeolites, foraminifers, and heavy minerals.

The nannofossil oozes are impure with calcite ranging from approximately 35 to 60 volume percent; the remainder consists of $15 \%-20 \%$ clay minerals, $10 \%-30 \%$ cristobalite and quartz combined, and $10 \%-15 \%$ zeolite (Figures 5 and 6). Small quantities of K-feldspar, plagioclase, tridymite, and heavy minerals are also present. The clay-rich nannofossil oozes and nannofossil clays contain the same minerals as the oozes, but clay minerals and mica combined make up approximately $35 \%-50 \%$ (Figure 7 ). Calcite ranges from $10 \%-30 \%$ and quartz varies up to $35 \%$ of the total. Zeolites are present in only trace amounts.

The calcareous sediments are stiff to semilithified and show little diagenetic alteration other than compaction and some recrystallization of calcareous fossils. Lithified specimens owe their condition to the presence of microcrystalline and cryptocrystalline quartz and cristobalite. A few dolomite nodules and scattered dolomite rhombs are present, and pyrite is widespread. Zeolites are abundant only at Site 259.

\section{Cenozoic Abyssal Plain Sediments}

Because the abyssal plain sites were chosen in areas where the acoustically layered unit is thin, relatively few
Cenozoic sediments were recovered from Sites 259, 260, 261 , and 263. The cored sediments consist chiefly of nannofossil ooze with lesser amounts of clay (Tablev). The recovered material ranges from Paleocene to Recent in age, but most of it is late Tertiary (Figure 3).

\section{Nannofossil Ooze and Foraminiferal Nannofossil Ooze}

The Cenozoic calcareous sediments are chiefly nannofossil ooze and foraminiferal nannofossil ooze with lesser amounts of radiolarian ooze, zeolite-rich nannofossil ooze, and nannofossil-rich clay. All are light colored, being predominently grayish orange to orange pink, but grading into shades of light brown and light green with increasing clay. Some of the oozes and nannofossil clays exhibit vague color banding and irregular mottling (Plate 12, Figure 3); others have irregular color laminae (Plate 12, Figure 4).

These sediments are thin to thick bedded, typically forming layers a few meters thick, interbedded with clay. Many of the foraminiferal nannofossil oozes are graded, although in the cores they appear massive (Plate 12, Figure 6; Plate 13, Figures 1 and 4). Graded layers range from 1 to 2 meters thick and are typically bounded above and below by dark clays.

The oozes are poorly sorted and silty with an average grain size of $8.6 \phi$. Foraminiferal oozes are generally coarser grained and contain up to $40 \%$ sand-size material (Figure 10). Zeolites and foraminiferal fragments make up most of the silt- and sand-size material.

An average nannofossil ooze consists of $85 \%-90 \%$ nannofossils, $5 \%-10 \%$ foraminifers, and $2 \%-3 \%$ detrital quartz with traces of feldspar, clay, and zeolite. In some samples clinoptilolite and phillipsite make up 10\%-30\% combined, resulting in a corresponding decrease in the percent of nannofossils. Mica is typically present and some specimens also contain small quantities of montmorillonite and kaolinite (Figures 5-7). Calcite is the common carbonate mineral, but aragonite is abundant in the uppermost oozes at Site 263. Heavy minerals are chiefly opaques (largely pyrite) with lesser amounts of hornblende, garnet, zircon, and tourmaline. 
TABLE 3

Summary of Lithologic Features of Cenozoic Abyssal Plain Sediments of the Eastern Indian Ocean

\begin{tabular}{|c|c|c|}
\hline Unit & $\begin{array}{l}\text { Radiolarian, Foram Nanno, } \\
\text { Nanno Oozes }\end{array}$ & Clays \\
\hline Distribution & $\begin{array}{l}\text { Site } 259, \text { Cores } 1,4-7 \\
\text { Site } 260 \text {, Cores } 2-4 \\
\text { Site } 261 \text {, Core } 4 \\
\text { Site } 263 \text {, Cores } 1-3\end{array}$ & $\begin{array}{l}\text { Site } 259 \text {, Cores } 1,3-5,7,8 \\
\text { Site } 260 \text {, Cores } 1-5 \\
\text { Site } 261 \text {, Cores } 2-4\end{array}$ \\
\hline Thickness (m) & 65 & 24 \\
\hline Induration & Soft to stiff & Stiff \\
\hline Color & $\begin{array}{l}\text { Chiefly pale orange, orange- } \\
\text { pink, grayish-orange with } \\
\text { some light gray, brown, and } \\
\text { green }\end{array}$ & $\begin{array}{l}\text { Chiefly dark yellowish-brown } \\
\text { to grayish-orange with some } \\
\text { greenish-gray }\end{array}$ \\
\hline $\begin{array}{l}\text { Primary } \\
\text { Structures }\end{array}$ & $\begin{array}{l}\text { Thin bedded and laminated; } \\
\text { graded sequences of foram } \\
\text { ooze; color mottled; some } \\
\text { clay balls }\end{array}$ & $\begin{array}{l}\text { Thin to medium bedded, rare } \\
\text { laminae; indistinctly mottled, } \\
\text { vaguely streaked; often } \\
\text { deformed or brecciated due to } \\
\text { drilling }\end{array}$ \\
\hline $\begin{array}{l}\text { Secondary } \\
\text { Structures }\end{array}$ & $\begin{array}{l}\text { Rare manganese nodules and } \\
\text { some dolomite nodules }\end{array}$ & $\begin{array}{l}\text { Zeolite-cemented aggregates, } \\
\text { iron oxide layers and nodules, } \\
\text { and rare manganese nodules }\end{array}$ \\
\hline $\begin{array}{l}\text { Mean Grain } \\
\text { Size }(\phi)\end{array}$ & $\begin{array}{l}\text { Foram oozes } 5.8 \\
\text { Rad and nanno oozes } 8.6\end{array}$ & 9.8 \\
\hline Sorting $(\phi)$ & $\begin{array}{l}\text { Foram oozes } 3.5 \\
\text { Rad and nanno oozes } 2.6\end{array}$ & 2.7 \\
\hline $\begin{array}{l}\text { Sand:Silt: } \\
\text { Clay Ratio (\%) }\end{array}$ & $\begin{array}{l}\text { Foram oozes } 45: 23: 32 \\
\text { Rad and nanno oozes } 1: 37: 62\end{array}$ & $1: 30: 69$ \\
\hline $\begin{array}{l}\text { Chief } \\
\text { Constituents }\end{array}$ & $\begin{array}{l}\text { Chiefly nannos and forams } \\
\text { with varying percentages of } \\
\text { micarb fragments, zeolite, } \\
\text { clay, radiolarians; zeolite- } \\
\text { rich oozes have montmorill- } \\
\text { onite, others have kaolinite }\end{array}$ & $\begin{array}{l}\text { Chiefly zeolitic clays with } \\
\text { clinoptilolite and phillipsite; } \\
\text { kaolinite, montmorillonite, and } \\
\text { some palygorskite; some samples } \\
\text { have abundant nannos or rads }\end{array}$ \\
\hline $\begin{array}{l}\text { Organic } \\
\text { Carbon }(\%)\end{array}$ & Average 0.2 & Average 0.2 \\
\hline $\begin{array}{l}\text { Carbonate } \\
\text { Carbon }(\%)\end{array}$ & Average 45 & Average 5 \\
\hline $\begin{array}{l}\text { Diagenetic } \\
\text { Minerals }\end{array}$ & $\begin{array}{l}\text { Clinoptilolite after rads; } \\
\text { pyrite filling forams; } \\
\text { isolated dolomite rhombs, } \\
\text { sparry calcite }\end{array}$ & $\begin{array}{l}\text { Zeolite-cemented aggregates; } \\
\text { gypsum, cristobalite, paly- } \\
\text { gorskite(?), and rare } \\
\text { manganese nodules; }\end{array}$ \\
\hline
\end{tabular}

Foraminiferal nannofossil oozes are similar to the nannofossil oozes except that foraminifers comprise an average of $30 \%$. The foraminifers are either whole or broken (Plate 5, Figure 5) and some are abraded. Many of the micarb fragments, which are abundant in these sediments, are probably broken foraminifers. The foraminiferal oozes typically have high intraforam porosity (Plate 5, Figure 3 ) with the intertest pores being filled with nannofossil micrite. Detrital quartz and feldspar are slightly more abundant in these sediments than in the nannofossil oozes, and glauconite is locally present.
Chemically, the calcareous oozes are all similar, averaging about $70 \%-75 \% \mathrm{CaCO}_{3}, 17 \% \mathrm{SiO}_{2}$, and $5 \%$ $\mathrm{Al}_{2} \mathrm{O}_{3}$ (Table 4).

Radiolarian oozes are locally present on the sea floor where they form the thin transparent layer at the top of the acoustically layered unit. These oozes consist chiefly of radiolarians and diatoms with $10 \%-20 \%$ montmorillonite, zeolite, and plagioclase combined.

Pyrite and zeolite are the most abundant diagenetic minerals in the Cenozoic oozes. Pyrite typically fills or partly fills foraminifers (Plate 5, Figures 3 and 5), and clinoptilolite occurs either in small clots filling probable 
TABLE 4

Average Chemical Analyses of Cenozoic Abyssal Plain Sediments of the Eastern Indian Ocean

\begin{tabular}{|c|c|c|c|c|}
\hline Element & $\begin{array}{l}\text { Nanno } \\
\text { Ooze }\end{array}$ & $\begin{array}{c}\text { Foram } \\
\text { Nanno } \\
\text { Ooze }\end{array}$ & $\begin{array}{c}\text { Zeolitic } \\
\text { Clay }\end{array}$ & $\begin{array}{l}\text { Radiolarian } \\
\text { Clay }\end{array}$ \\
\hline \multicolumn{5}{|l|}{ Major $^{a}$} \\
\hline $\mathrm{SiO}_{2}$ & 15.8 & 11.8 & 48.1 & 56.0 \\
\hline $\mathrm{TiO}_{2}$ & 0.20 & 0.11 & 0.60 & 0.55 \\
\hline $\mathrm{A}_{2}{ }_{2} \mathrm{O}_{3}$ & 4.8 & 2.2 & 13.7 & 14.1 \\
\hline $\mathrm{Fe}_{2} \mathrm{O}_{3}$ & 2.1 & 1.3 & 6.8 & 4.3 \\
\hline $\mathrm{MgO}$ & 1.2 & 1.4 & 3.0 & 2.3 \\
\hline $\mathrm{MnO}$ & 0.12 & 0.02 & 0.80 & 1.2 \\
\hline $\mathrm{CaO}$ & 36.7 & 42.5 & 4.9 & 1.1 \\
\hline $\mathrm{Na}_{2} \mathrm{O}$ & 1.9 & 1.6 & 2.8 & 4.8 \\
\hline $\mathrm{K}_{2} \mathrm{O}$ & 0.8 & 0.5 & 2.7 & 2.2 \\
\hline $\mathrm{P}_{2} \mathrm{O}_{5}$ & 0.07 & 0.09 & 0.40 & 0.14 \\
\hline $\mathrm{Cr}_{2} \mathrm{O}_{3}$ & $<0.1$ & $<0.1$ & $<0.1$ & $<0.1$ \\
\hline $\mathrm{v}_{2} \mathrm{O}_{5}$ & $<0.05$ & $<0.05$ & $<0.05$ & $<0.05$ \\
\hline LOI & 36.4 & 38.5 & 16.2 & 13.0 \\
\hline Total & 100.2 & 100.2 & 100.2 & 99.8 \\
\hline $\mathrm{CO}_{2}$ & 30.1 & 33.8 & 2.4 & 2.2 \\
\hline $\mathrm{H}_{2} \mathrm{O}$ & 4.1 & 3.6 & 12.5 & 12.8 \\
\hline \multicolumn{5}{|l|}{ Trace $^{b}$} \\
\hline $\mathrm{Ba}$ & 470 & 260 & 600 & 1300 \\
\hline $\mathrm{Li}$ & 20 & 10 & 47 & 50 \\
\hline $\mathrm{Cr}$ & 20 & 20 & 453 & 700 \\
\hline $\mathrm{Pb}$ & 9 & 5 & 19 & 11 \\
\hline $\mathrm{Zn}$ & 60 & 40 & 153 & 140 \\
\hline Co & 2 & 2 & 47 & 35 \\
\hline $\mathrm{Ni}$ & 28 & 17 & 165 & 150 \\
\hline
\end{tabular}

${ }^{\mathrm{a}}$ In percent.

${ }^{\text {In }}$ ppm.

radiolarian molds (Plate 7 , Figure 1) or as isolated crystals. Dolomite rhombs and small quantities of sparry calcite are also present. The dolomite rhombs are scattered through the sediment, whereas calcite fills foraminifers along with pyrite.

\section{Clay}

Approximately 24 meters of Cenozoic clay were recovered, chiefly from Site 260 . Here, the clay forms a relatively pure unit at the top of the Cenozoic section; elsewhere the clay occurs in thin layers interbedded with calcareous oozes (Plate 13, Figure 1).

Usually the clays are dark yellowish brown to grayish orange or greenish gray; lighter colors are associated with higher percentages of calcareous material. Most of the clays are streaked, mottled, and generally deformed (Plate 13, Figure 3); some retain a vague color banding and irregular color lamination.

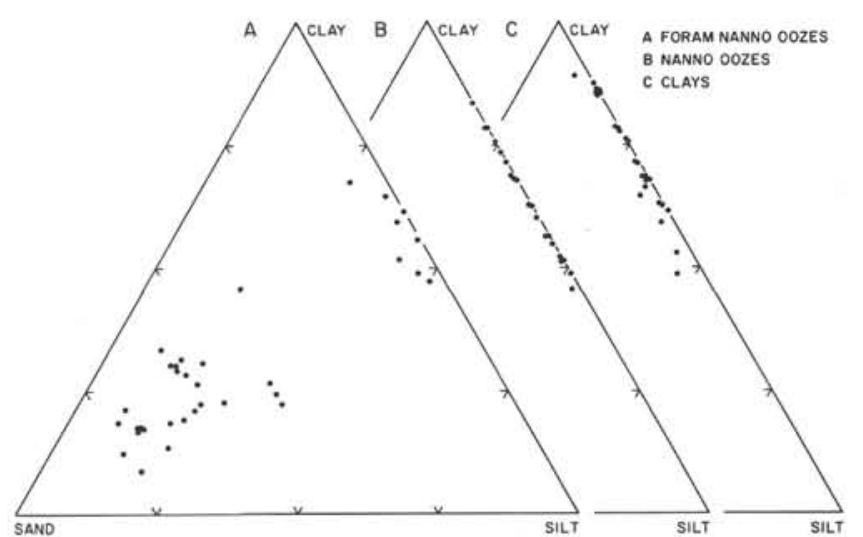

Figure 10. Texture of Cenozoic abyssal plain sediments of the eastern Indian Ocean.

Texturally, these are very poorly sorted clays aand silty clays with a mean grain size of $9.8 \phi$ (Figure 10). Zeolite makes up most of the silt-size material; sand-size grains are chiefly foraminifers.

These clays are rich in palygorskite as well as kaolinite and montmorillonite (Figure 9). Clinoptilolite makes up $15 \%-20 \%$, scattered phillipsite $5 \%-10 \%$, quartz $15 \%$, and cristobalite $10 \%$. Trace amounts of feldspar, gypsum, and opaque minerals are also common. Many clays contain a few percent of nannofossils and occasional foraminifers. Some of the fossiliferous clays grade into clay-rich nannofossil ooze, and minor radiolarian clay is also present. The latter averages about $70 \%$ clay and $20 \%$ siliceous fossils with the remainder composed of quartz, feldspar, zeolite, and opaque minerals.

Compared to the Mesozoic clays, Cenozoic clays are somewhat lower in $\mathrm{SiO}_{2}$ and slightly higher in $\mathrm{Al}_{2} \mathrm{O}_{3}$ and $\mathrm{CaO}$ (Table 4). These differences are due to the high percentages of cristobalite and quartz in the Mesozoic clays, minerals that are very rare in the younger sediments.

\section{Cenozoic Sediments of the Timor Trough}

The Cenozoic sequence in the Timor Trough was continuously cored to a depth of 442 meters. Nannofossil ooze comprises nearly $85 \%$ of the material recovered, with foraminiferal ooze making up most of the remainder. The nannofossils and foraminiferal oozes, which extend to 414.5 meters below the sea floor, unconformably overlie 13 meters of foraminifer-rich dolomitic limestone which in turn rests on a sequence of dolomitic shell calcarenite at the bottom of the hole (Figure 3). Four thin layers of volcanic ash are interbedded with the oozes.

\section{Nannofossil Ooze}

The nannofossil oozes are typically soft to stiff, very fine-grained, poorly sorted, homogeneous sediments. Most are uniformly grayish olive to olive-gray (Plate 12, Figure 6) but some show broad color bands (Plate 13, Figure 4) or laminae (Plate 12, Figure 8). The laminae may be either regular or irregular and some are inclined. A few specimens have dark gray horizontal streaks and 
laminae rich in pyrite, clay, and plant debris (Plate 13, Figure 5).

All of the nannofossil oozes are somewhat silty with an average grain size of 9.3, and a sand-silt-clay ratio of 4\%:32\%:64\% (Figure 11). The silt component consists chiefly of foraminifers and micarb fragments.

Nannofossils comprise from $25 \%-70 \%$ of these oozes and average about $50 \%-55 \%$. Foraminifers, radiolarians, micärb fragments, and clay minerals make up most of the remainder, but trace amounts of quartz, feldspar, heavy minerals, pyrite, zeolite, and glauconite are also present (Plate 6, Figures 3, 5, and 6). Aragonite is present throughout the section, ranging from $3 \%$ to $33 \%$ based on X-ray diffraction analysis (Figure 12). Both kaolinite and montmorillonite are present and most specimens also contain 5\%-15\% combined of mica and chlorite. Organic carbon is relatively high, averaging about $0.9 \%$; total carbon averages about $6 \%$ and $\mathrm{CaCO}_{3}$ about $45 \%$.

Diagenetic pyrite is widespread and locally abundant. It fills foraminifers and occurs as discrete grains scattered through the matrix (Plate 6, Figure 6). In some specimens it completely replaces the matrix, forming pyrite nodules (Plate 7, Figure 6).

The nannofossil oozes are quite variable in chemical composition ranging from $20 \%$ to $40 \% \mathrm{SiO}_{2}, 18 \%-30 \%$ $\mathrm{CaO}$, and $7 \%-10 \% \mathrm{Al}_{2} \mathrm{O}_{3}$ with the remainder consisting chiefly of $\mathrm{CO}_{2}$ (Table 5). Variations in chemical composition closely follow mineralogical variations with radiolarian-rich varieties being relatively enriched in $\mathrm{SiO}_{2}$ and depleted in $\mathrm{CaO}$ compared to the other oozes.

\section{Foraminiferal Oozes}

Foraminiferal oozes and nannofossil foraminiferal oozes make up only about $16 \%$ of the cored sequence in the Timor Trough, and occur chiefly in graded layers, up to 4 meters thick, interlayered with nannofossil oozes. The foraminiferal oozes occur chiefly in two intervals; 0-150 meters and 337.5-414 meters below the sea floor (Figure 3).

The foraminiferal oozes are pale olive to grayish-olive and are either homogeneous or faintly laminated and mottled (Plate 12, Figure 1). Distinct mottles with sharp boundaries probably represent burrows. Some

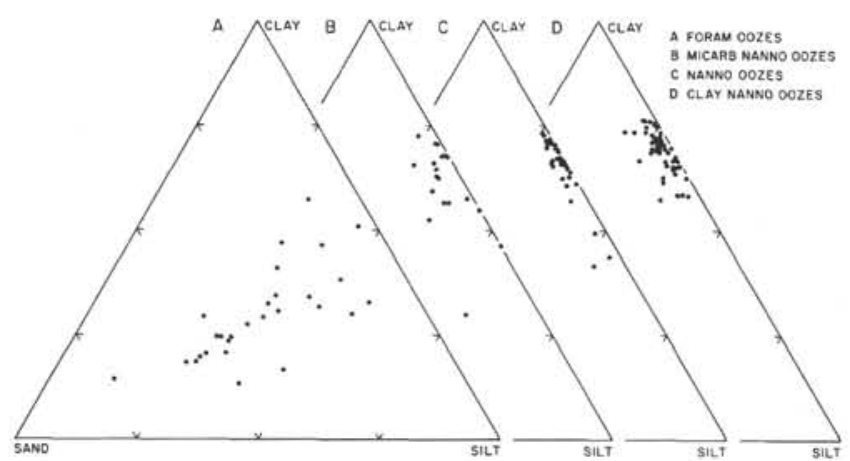

Figure 11. Texture of Cenozoic sediments of the Timor Trough. specimens show minor cross-lamination. The oozes become more indurated with depth, ranging from soft near the top of the section to semilithified at the base. Compared to the nannofossil oozes, these sediments are relatively coarse grained, often containing up to $40 \%$ or more sand-size material, dominantly foraminifers and micarb fragments (Figure 11). Some layers consist chiefly of detrital foraminiferal silt and sand. All of these oozes are graded, although in many the grading can be detected only by grain-size analysis.

Three main compositional varieties are present: detrital foraminiferal ooze or sand, micarb-rich foraminiferal ooze, and nannofossil foraminiferal ooze. Foraminifers range from $30 \%$ to $75 \%$ and average about $50 \%$. Micarb fragments, some of which are probably fragments of foraminifers, are the next most common constituent, ranging from $10 \%$ to $60 \%$ (Plate 8 , Figure 1). Most specimens have from $5 \%$ to $10 \%$ clay minerals and up to $20 \%$ nannofossils. Quartz, pyrite, and dolomite rhombs usually account for $1 \%-2 \%$ each, and trace amounts of siliceous fossils, heavy minerals, plant debris, and glauconite are always present. Fragments of broken molluscs are also common (Plate 8, Figure 4).

Calcite and aragonite are the most abundant minerals, averaging about $80 \%$ of most specimens. Aragonite is most abundant in the relatively pure foramiferal oozes where it reaches a maximum of $42 \%$; elsewhere it rarely exceeds 5\% (Figure 12). Clay minerals, chlorite, and mica combined comprise about $5 \%$ whereas quartz, including both detrital grains and microcrystalline material, averages about $8 \%$. Organic carbon is considerably lower in these sediments than in the nanno oozes averaging about $0.3 \%$; total carbon is about $9.3 \%$ and $\mathrm{CaCO}_{3}$ about $74 \%$.

Pyrite and dolomite are the most common diagenetic minerals. Pyrite partly to completely fills foraminifers, whereas dolomite occurs in isolated rhombs (Plate 8, Figure 2). Many of the molluscan fragments have been bored by endolithic algae and fungi, and the bores filled with micrite. Secondary sparry calcite fills some foraminifers.

\section{Volcanic Ash}

Thin layers of white volcanic ash are interbedded with the oozes at depths of 263.9, 265.1, 304.3, and 325.1 meters. The ash layers range from 2 to $5 \mathrm{~cm}$ in thickness and consist chiefly of glass shards. Hornblende, hypersthene, plagioclase, opaque minerals, and rare quartz make up from $5 \%$ to $10 \%$ and suggest a dacitic to rhyodacitic composition.

\section{Dolomitic Limestone and Dolomitic Calcarenite}

Unconformably underlying the nannofossil and foraminiferal oozes are two shallow-water deposits. The uppermost consists of 13 meters of greenish-gray to pale olive, semilithified dolomitic limestone (Plate 13, Figure 7). This material consists chiefly of foraminifers and dolomite rhombs with lesser amounts of quartz, pyrite, and glauconite. Rounded and abraded molluscan fragments are also common (Plate 8, Figure 3). Bulk Xray diffraction analysis indicates an average composition of $53 \%$ calcite, $45 \%$ calcian dolomite, $1 \%$ 
SITE 262 BULK X-RAY

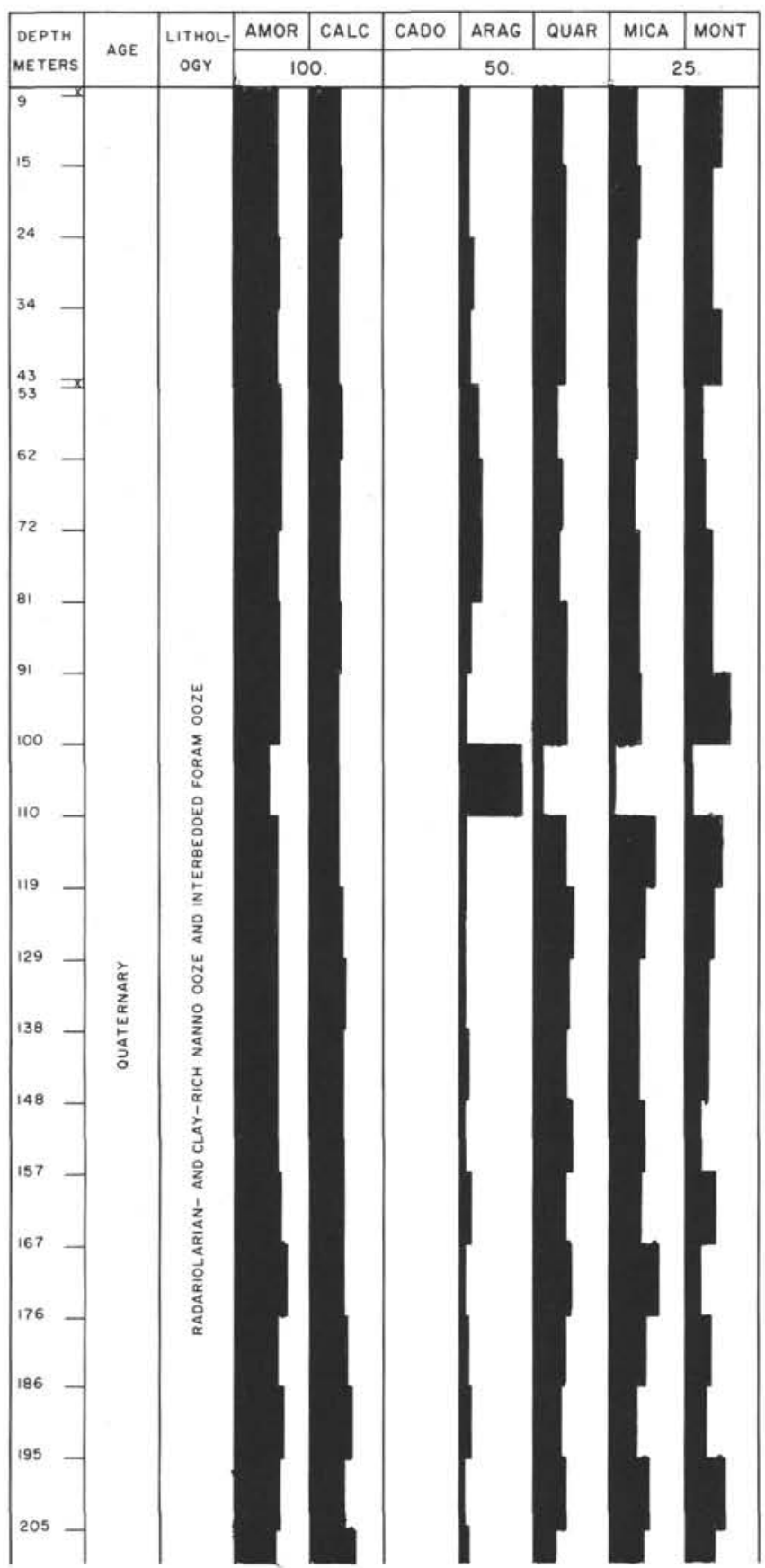

Figure 12. Distribution of minerals in sediments from Site 262 based on X-Ray diffraction analysis. Only minerals in excess of $10 \%$ are included.

quartz, and $1 \%$ aragonite (Figure 12). Chemical analyses reveal a relatively pure limestone with about $7 \% \mathrm{MgO}$ (Table 5).

The limestone has undergone extensive diagenetic recrystallization and dolomitization. Most of the dolomite is believed to be secondary because it replaces foraminifers and molluscan fragments. Much of the fine-grained micritic matrix also consists of dolomite (Plate 9, Figure 1). Euhedral calcite crystals often grow from the walls of foraminifers (Plate 7, Figures 2-4) and

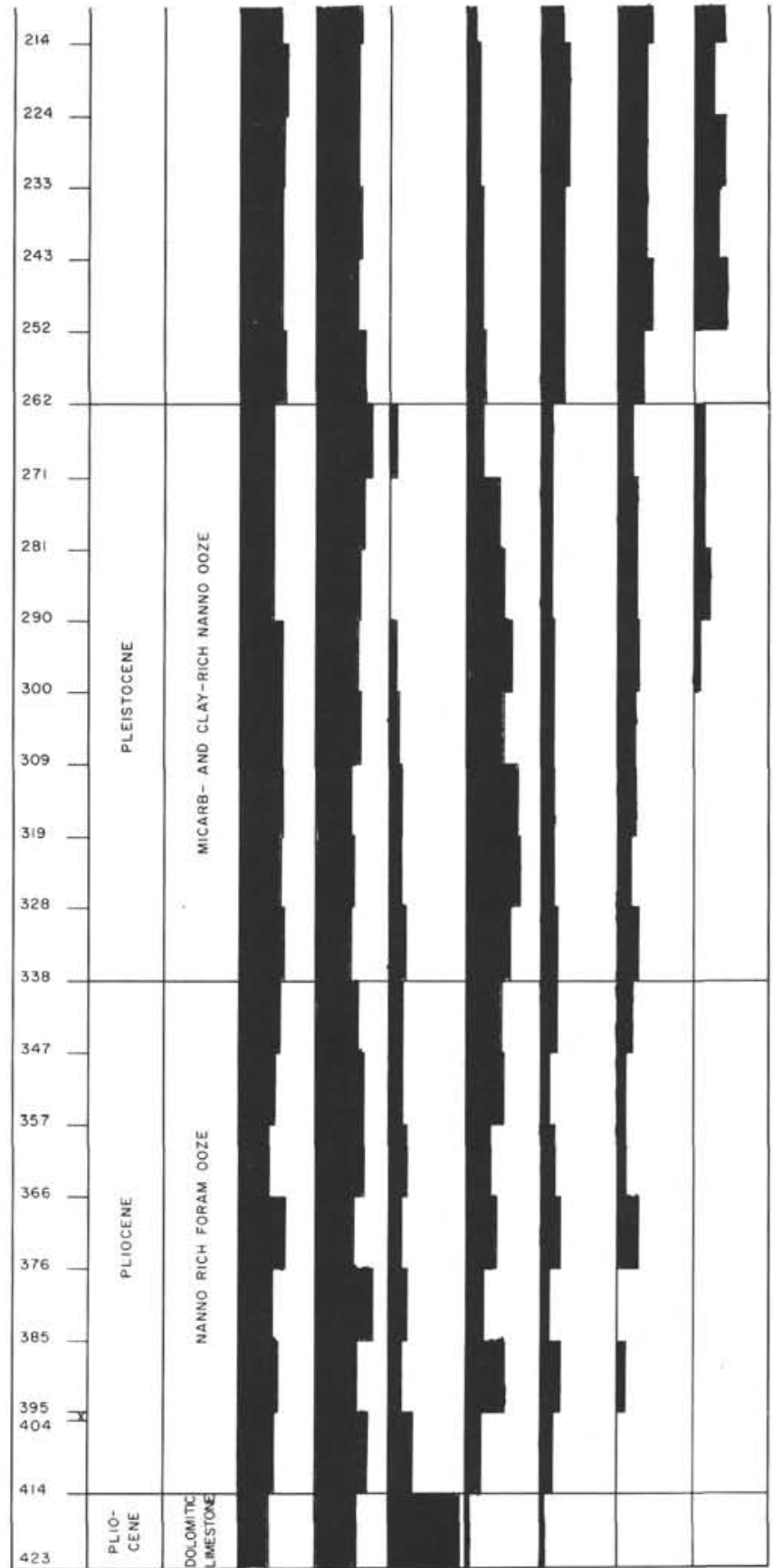

Figure 12. (Continued).

syntaxial overgrowths of calcite occur on echinoderm allochems (Plate 8, Figure 6).

This unit is interpreted to be of shallow-water origin because of the presence of numerous rounded and abraded molluscan fragments and because of the extensive boring of these fragments by shallow-water algae and fungi.

Immediately beneath the dolomitic limestone is a unit of yellowish- to greenish-gray, lithified, dolomitic shell calcarenite. This material consists of whole and broken 
TABLE 5

Average Chemical Analyses of Cenozoic

Sediments from the Timor Trough

\begin{tabular}{|c|c|c|c|c|c|c|}
\hline Element & $\begin{array}{l}\text { Clay } \\
\text { Nanno } \\
\text { Ooze }\end{array}$ & $\begin{array}{l}\text { Foram-Rich } \\
\text { Nanno Ooze }\end{array}$ & $\begin{array}{c}\text { Rad } \\
\text { Nanno } \\
\text { Ooze }\end{array}$ & $\begin{array}{c}\text { Nanno } \\
\text { Foram } \\
\text { Ooze }\end{array}$ & $\begin{array}{c}\text { Micarb } \\
\text { Foram } \\
\text { Ooze }\end{array}$ & $\begin{array}{l}\text { Dolomitic } \\
\text { Limestone }\end{array}$ \\
\hline \multicolumn{7}{|l|}{ Major $^{\mathrm{a}}$} \\
\hline $\mathrm{SiO}_{2}$ & 24.6 & 23.8 & 38.5 & 14.6 & 5.4 & 1.5 \\
\hline $\mathrm{TiO}_{2}$ & 0.28 & 0.32 & 0.38 & 0.14 & 0.05 & 0.02 \\
\hline $\mathrm{A}_{2}{ }_{2} \mathrm{O}_{3}$ & 7.3 & 7.7 & 9.5 & 3.1 & 1.3 & 0.10 \\
\hline $\mathrm{Fe}_{2} \mathrm{O}_{3}$ & 3.1 & 2.8 & 4.0 & 1.6 & 0.8 & 0.3 \\
\hline $\mathrm{MnO}$ & 0.05 & 0.02 & 0.12 & $<0.02$ & $<0.02$ & $<0.02$ \\
\hline $\mathrm{MgO}$ & 2.1 & 1.7 & 2.0 & 2.5 & 5.8 & 7.0 \\
\hline $\mathrm{CaO}$ & 29.1 & 28.2 & 18.4 & 39.5 & 43.2 & 44.0 \\
\hline $\mathrm{Na}_{2} \mathrm{O}$ & 1.7 & 1.8 & 2.1 & 1.3 & 0.9 & 0.7 \\
\hline $\mathrm{K}_{2} \mathrm{O}$ & 1.3 & 1.2 & 1.6 & 0.7 & 0.3 & 0.1 \\
\hline $\mathrm{P}_{2} \mathrm{O}_{5}$ & 0.14 & 0.09 & 0.13 & 0.16 & 0.15 & 0.09 \\
\hline $\mathrm{Cr}_{2} \mathrm{O}_{3}$ & $<0.1$ & $<0.1$ & $<0.1$ & $<0.1$ & $<0.1$ & $<0.1$ \\
\hline $\mathrm{v}_{2} \mathrm{O}_{5}$ & $<0.05$ & $<0.05$ & $<0.05$ & $<0.05$ & $<0.05$ & $<0.05$ \\
\hline LOI & 30.5 & 32.7 & 23.2 & 35.0 & 40.6 & 44.4 \\
\hline Total & 100.4 & 100.5 & 100.1 & 98.8 & 98.7 & 100.3 \\
\hline $\mathrm{CO}_{2}$ & 23.3 & 22.8 & 14.1 & 32.4 & 36.9 & 41.0 \\
\hline $\mathrm{H}_{2} \mathrm{O}$ & 2.9 & 6.3 & 6.7 & 3.7 & 1.5 & 1.1 \\
\hline \multicolumn{7}{|l|}{ Trace $^{b}$} \\
\hline $\mathrm{Sr}$ & 1500 & 1200 & 700 & 2000 & 1125 & 680 \\
\hline $\mathrm{Ba}$ & 340 & 2500 & 440 & 80 & 30 & 20 \\
\hline $\mathrm{Li}$ & 30 & 25 & 30 & 15 & $<10$ & $<10$ \\
\hline $\mathrm{Cu}$ & 30 & 35 & 40 & 12 & 5 & 3 \\
\hline $\mathrm{Pb}$ & 50 & 5 & 10 & 11 & $<1$ & 2 \\
\hline $\mathrm{Zn}$ & 80 & 70 & 90 & 40 & 19 & 13 \\
\hline Co & 8 & 2 & 6 & $<1$ & 1 & 1 \\
\hline $\mathrm{Ni}$ & 30 & 27 & 36 & 12 & 2 & 7 \\
\hline
\end{tabular}

${ }^{\mathrm{a}}$ In percent.

bIn ppm.

foraminifers, molluscan fragments, echiroderm debris, and sponge spicules along with minor detrital quartz and heavy minerals. The grain-supported fossil debris is abraded, and is cemented by clear sparry calcite. The shallow-water nature of this unit is indicated not only by the texture but by the presence of abundant shallowwater foraminifers. The thickness of the unit is unknown because drilling was terminated after only 15 meters had been penetrated.

\section{DIAGENESIS OF MESOZOIC AND CENOZOIC SEDIMENTS}

Diagenetic minerals are widespread and abundant in both Mesozoic and Cenozoic sediments. Mesozoic sediments are characterized by abundant diagenetic quartz and cristobalite, by nodules of dolomite and barite, and by framboids and scattered grains of pyrite.
Pyrite and zeolite are the most common diagenetic minerals in the Cenozoic sediments.

\section{Mesozoic Sediments}

Most of the Mesozoic clays are indurated and extensively silicified (Figures 5-7); some contain up to $80 \%$ microcrystalline and cryptocrystalline quartz and cristobalite. The silica minerals are usually intimately mixed with clay minerals and are not visible in smear slides and thin sections. Scanning electron micrographs (SEM) of some specimens show that cristobalite occurs in small spherulites (Plate 8, Figure 4 of Proto-Decima, this volume). Occasionally, radiolarian molds are filled with fibrous chalcedony and microcrystalline quartz (Plate 1, Figure 4; Plate 2, Figure 5). At any given site quartz and cristobalite vary inversely and usually quartz increases somewhat with depth. The silicification of 
these clays is relatively uniform and bedded cherts are absent.

The widespread occurrence and uniform distribution of quartz and cristobalite suggest that the silica was derived from solution of siliceous fossils or volcanic glass and reprecipitated in the pore space of the clays (von Rad and Rösch, 1972; Ernst and Calvert, 1969). Solution of siliceous fossils seems to be the most likely source because radiolarians in these sediments are extensively corroded and recrystallized and there is no independent evidence of original volcanic glass. The distribution of quartz and cristobalite in these sediments suggests that cristobalite formed first and later recrystallized to chalcedonic and microcrystalline quartz. The diagenetic processes involved in solution of siliceous fossils, precipitation of cristobalite, and recrystallization of quartz are dependent primarily on time, temperature, and character of the pore solutions (Ernst and Calvert, 1969).

Dolomite and barite nodules, ranging from less than 5 $\mathrm{mm}$ to $10 \mathrm{~cm}$ across, are irregularly present throughout the Mesozoic sediments. Dolomite nodules are typically light brown, very dense masses of small dolomite crystals (Plate 3, Figure 1). In thin section the dolomite nodules and layers consist of curved rhombs which are often zoned with distinct, subrounded, dark cores (Plate 4 , Figures 1 and 2). The zoning may reflect a change in pore water chemistry, with the dark cores being precipitated when interstitial solutions were enriched in iron. Later changes in pore water chemistry might have caused solution of the edges and corners of the iron-rich dolomite, and promoted precipitation of clear dolomite about the early-formed cores. Alternatively, the dark subrounded cores may represent detrital dolomite grains about which clear, authigenic dolomite later grew (Sabins, 1962; Davies and Supko, 1973). Some nodules consist of anhedral to subhedral interlocking, unzoned dolomite crystals (Plate 3, Figure 6). Barite nodules are yellowish gray and consist of fine-grained granular aggregates of anhedral crystals that apparently replaced a clay matrix (Plate 3, Figure 5).

Secondary calcite is also common in the claystones. It commonly occurs as narrow veinlets cutting dolomite and barite nodules (Plate 3, Figures 1-3) and as small granular aggregates (Plate 3, Figure 4). The veinlets consist of radiaxial fibrous crystals growing perpendicular to the vein wall and becoming coarser grained toward the center (Plate 3, Figure 2; Plate 4, Figure 3). This arrangement suggests growth of the crystals into an open fracture rather than as a replacement of the matrix. Sparry calcite cement also occurs in some claystones, particularly the kaolinitic claystones at the base of the section at Site 263 (Plate 4, Figures 5 and 6). The calcite was presumably derived from solution of foraminifers and calcareous nannoplankton.

Zeolites are also abundant in these sediments, particularly in the upper part of the section. Clinoptilolite, the most common variety, occurs in clusters of tabular and blocky crystals (Plate 9, Figure 2) apparently filling radiolarian molds (Plate 1, Figures 1-3). Phillipsite is also locally present but is always subordinate to clinoptilolite.
The zeolitic claystones are typically very rich in palygorskite. This mineral, a hydrated, high-magnesium chain silicate, is probably formed by diagenetic alteration of montmorillonitic clay by magnesian-rich solutions (von Rad and Rösch, 1972; Hathaway and Sachs, 1965). According to Hathaway and Sachs (1965) palygorskite can form in the marine environment only in the presence of silica hydrogel. Solution of volcanic glass is a simple means of obtaining excess silica, and palygorskite commonly occurs in association with montmorillonite, clinoptilolite, and residual volcanic glass. This association of minerals suggests that the necessary silica may be derived from devitrification of glass to montmorillonitic clay (Hathaway and Sachs, 1965). Residual glass is absent in the eastern Indian Ocean sediments of Mesozoic age, but the association of montmorillonite, palygorskite, and clinoptilolite suggests a volcanogenic origin for the zeolitic clays. Alternatively, the excess silica could have been derived from solution of siliceous fossils. However, this does not explain the close correlation between palygorskite and zeolite in these sediments.

Pyrite is irregularly distributed throughout the Mesozoic sediments. In the oozes it usually fills foraminifers, and in the clays it occurs as framboids and isolated grains (Plate 2, Figure 2). The abundant pyrite indicates that reducing conditions prevailed during much of the diagenesis. Also the occurrence of dolomite nodules has been correlated with reducing conditions (Davies and Supko, 1973). The common association of pyrite and barite in these sediments suggests that chemical microenvironments prevailed during diagenesis.

\section{Cenozoic Sediments}

Pyrite is the most abundant and widespread diagenetic mineral in the Cenozoic sediments. It typically occurs as partial fillings of foraminifers (Plate 5, Figures 1-3 and 5; Plate 6, Figure 4; Plate 7, Figures 2 and 5) and occasionally as nodules completely replacing the matrix (Plate 7, Figure 6). It also occurs as irregular, anhedral grains scattered through the sediment (Plate 6, Figure 6).

Zeolite, chiefly clinoptilolite, is also common in these sediments. Here too it fills radiolarian molds (Plate 7, Figure 1) or occurs as isolated crystals. Euhedral dolomite rhombs are commonly scattered through the oozes (Plate 8 , Figure 2) but nodules are rare. Sparry calcite partially fills foraminifers, growing into the chambers from the test wall (Plate 7, Figures 2-4).

\section{COMPARISON OF MESOZOIC AND CENOZOIC ABYSSAL PLAIN SEDIMENTS}

Mesozoic sediments are predominantly dark gray to greenish-gray, stiff to indurated clays and claystones with lesser amounts of nannofossil ooze. The clays and claystones are very poorly sorted and generally fine grained, becoming noticeably silty only at Site 263 . Montmorillonite, mica, and microcrystalline silica comprise the bulk of these sediments, but zeolites are locally abundant. The zeolitic clays, which are lighter colored and less indurated than the siliceous claystones, are common only near the top of the Mesozoic sequence. 
Mesozoic oozes are rare and also occur chiefly near the top of the sequence associated with zeolitic clays. Calcareous sediments are stiff, light colored, impure nannofossil oozes containing up to $20 \%$ clay minerals. Zeolites, cristobalite, and quartz are sometimes present.

Cenozoic sediments of the layered unit are nannofossil and foraminiferal nannofossil ooze with subordinate amounts of clay and radiolarian ooze. The calcareous sediments are light colored, soft, thick bedded, and often graded. Typically they are pure nannofossil oozes with little clay, although zeolites are often abundant. The associated clays are light brown to dark yellow-brown, thin to thick bedded, and soft. They consist chiefly of montmorillonite, kaolinite, zeolite, and silica minerals.

As indicated by the above summary, the sediments of the transparent and layered units are distinctly different. The most obvious differences are in color, degree of induration, and bulk composition. However, other more subtle differences can be demonstrated by discriminant analysis. In discriminant analysis an original set of measurements on a sample is transformed into a single discriminant score. This score represents the samples position along a line defined by the linear discriminant function. $R_{1}$ and $R_{2}$ are points along this line that represent the multivariate means of the two groups of samples and $\mathrm{R}_{\mathrm{o}}$ is a point halfway between $R_{\mathbf{1}}$ and $R_{2}$. Samples of either group that plot on the opposite side of $R_{\mathrm{o}}$ are misclassified by the discriminant function. The distance between $R_{1}$ and $R_{2}$ (Mahalanobis'distance, $D^{2}$ ) is a measure of the degree to which two groups can be discriminated on the basis of the parameters chosen (Davis, 1973). If the two means are well separated and scatter about the means is small, discrimination between the two groups is excellent. If the means are close together the two groups are difficult to distinguish, especially if the two groups have large variances.

In this study discriminant analysis was applied to grain-size data using five parameters $\left(\phi 5, M_{z}, \sigma I, S k I\right.$, and $K^{\prime} G$ ) (Folk and Ward, 1957) and to carboncarbonate data using three parameters (total carbon, organic carbon, and percent $\mathrm{CaCO}_{3}$ ). In Figure 13 the textural characteristics of the Mesozoic sediments $\left(R_{1}\right)$ are compared with those of the Cenozoic sediments of the abyssal plains $\left(R_{\mathbf{2}}\right)$. The five textural parameters serve to distinguish these two units sharply with only 2 Mesozoic and 16 Cenozoic samples falling into opposite fields. Figure 14 demonstrates clearly the compositional differences between the two units based on carboncarbonate data. Here $R_{\mathbf{2}}$ is the discriminant mean of the Mesozoic samples and $R_{1}$ the mean of the Cenozoic samples. Out of 74 samples from both units, only 12 are misplaced. Separation on the basis of composition is even more pronounced if the Mesozoic sediments are compared with all of the Cenozoic samples, including those from Site 262 (Figure 15).

An attempt was also made to distinguish between the Mesozoic and Cenozoic sediments on the basis of heavy minerals, but the heavy mineral suites of the two units are not markedly different (Figure 16). Generally, Cenozoic sediments have more hornblende and epidote and less clinopyroxene than the Mesozoic sediments, but these differences are not pronounced if Site 262 is excluded. The heavy mineral assemblages in both the Cenozoic and Mesozoic sediments reflect provenance rather than temporal differences. Sites 259, 260, 261, and 263 have been just offshore from Western Australia since sedimentation began in the Late Jurassic or Early Cretaceous, and they have received a continental suite of heavy minerals throughout their depositional histories. On the other hand, the heavy minerals at Site 262 were derived largely from the island of Timor and are markedly different from those derived from the Australian shield.

\section{DISTRIBUTION $\mathrm{OF} \mathrm{CaCO}_{3}$ IN MESOZOIC AND CENOZOIC ABYSSAL PLAIN SEDIMENTS}

Figure 17 shows the variation of $\mathrm{CaCO}_{3}$ with depth in the abyssal plain sediments, and Figure 18 shows the stratigraphic position of carbonate-rich units at Sites 259, 260, 261, and 263. In Figure 18 the sites are arranged in geographic sequence from south to north. Nannofossils oozes and foraminiferal nannofossil oozes of Cenozoic age are abundant. at all four sites. Calcareous oozes are much less abundant in the Mesozoic sequence, and there are notable temporal variations in carbonate content. The Albian interval, for example, is considerably more calcareous than the preceding Aptian or Barremian intervals. Although less well documented, the Hauterivian-Valanginian interval appears to be more calcareous than the preceding Upper Jurassic interval, particularly at Site 261. The situation is unclear at Site 263 because of the uncertain age of the sediments. Based on nannofossils the entire sequence at Site 263 is Albian; however, dinoflagellates suggest an age from Aptian to Hauterivian. At Site 260 the lower part of the sequence was not penetrated.

Marked changes in carbonate content could result from changes in water temperature, which in turn would affect the depth of the carbonate compensation leve, or from relative changes in depth of the sea floor which could have raised or lowered the region above or below the carbonate compensation level. Alternatively, an increased rate of carbonate production by pelagic organisms, i.e., production in excess of solution, would have resulted in carbonate sedimentation in areas that were previously below the carbonate compensation level.

There is no evidence from other sources to suggest major vertical movements of the sea floor during this time, consequently large-scale bathymetric changes are perhaps the least likely explanation for the observed fluctuations in carbonate content. Increased water temperature and increased biogenic productivity are more likely possibilities. The question still remains, however, why such changes occurred. There is no evidence to suggest marked latitudinal changes in this region during the late Mesozoic. The region, however, was still a comparatively restricted ocean at that time, and microplate movements in the Wallaby Plateau region may have at times still further restricted the embayment. As a result, local climatic conditions (particularly changes in oceanic temperature) may have occurred quite readily, and these may have produced 


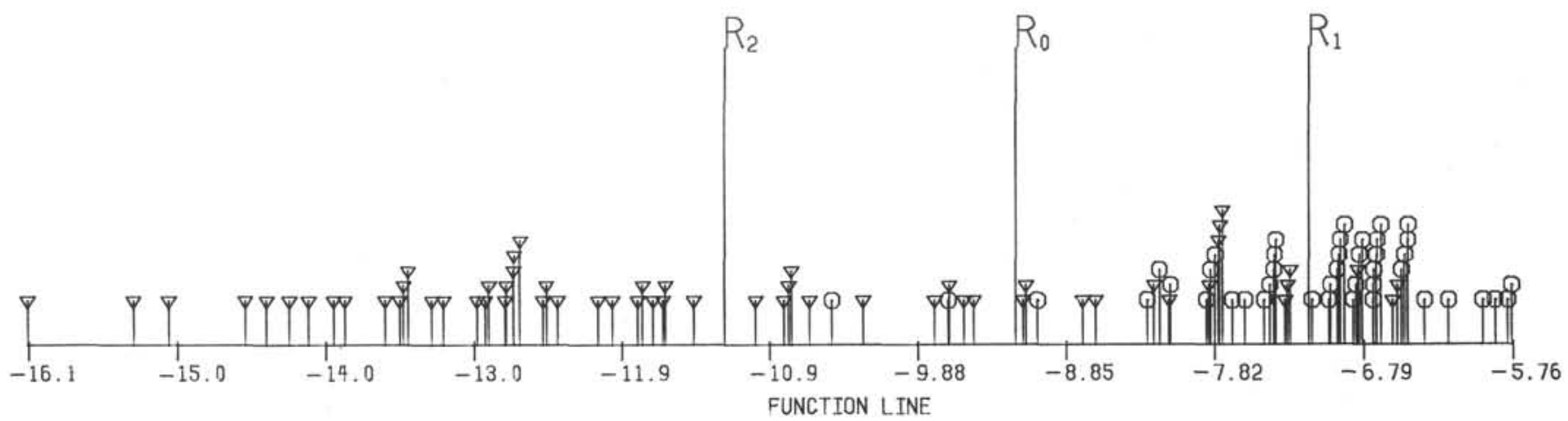

Figure 13. Projection of the discriminant scores of Mesozoic and Cenozoic abyssal plain sediments based on five grain size parameters $\left(\phi 5, \mathrm{M}_{\mathrm{Z}}, \sigma \mathrm{I}, S K_{\mathrm{I}}\right.$, and $\left.\mathrm{K}^{\prime} G\right) . \mathrm{R}_{1}$ is multivariate mean of Mesozoic sediments, $\mathrm{R}_{2}$ of the Cenozoic sediments, and $\mathrm{R}_{O}$ is the discriminant index. Triangles represent Mesozoic samples and octagons Cenozoic samples.

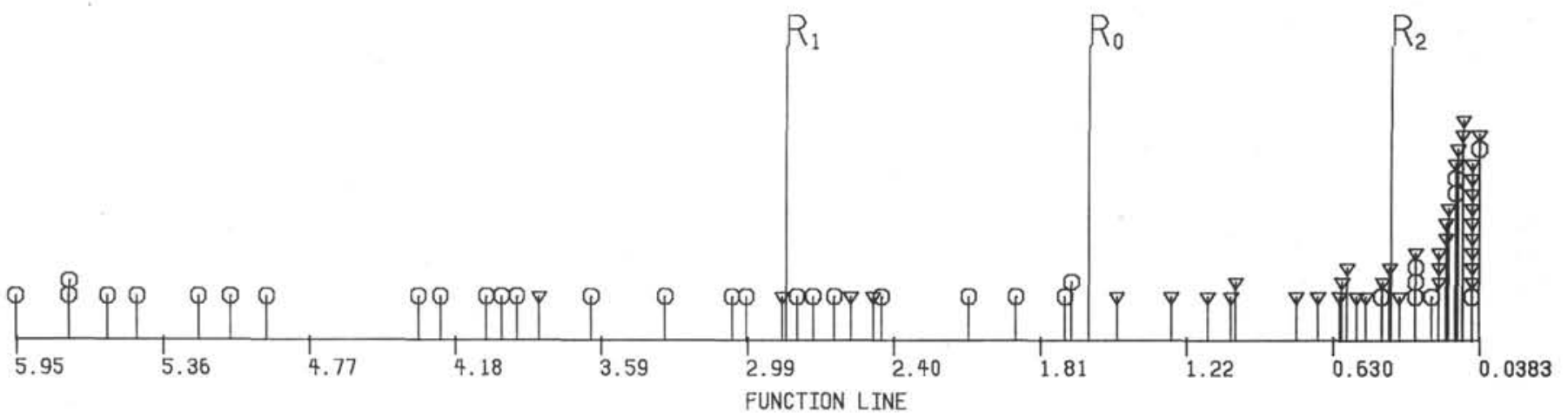

Figure 14. Projection of the discriminant scores of Mesozoic and Cenozoic abyssal plain sediments based on three parameters (percent total carbon, organic carbon, and $\mathrm{CaCO}_{3}$ ). $\mathrm{R}_{1}$ is multivariate mean of Cenozoic samples, $\mathrm{R}_{2}$ of the Mesozoic samples, and $\mathrm{R}_{O}$ is the discriminant index. Triangles represent Mesozoic samples and octagons Cenozoic samples.

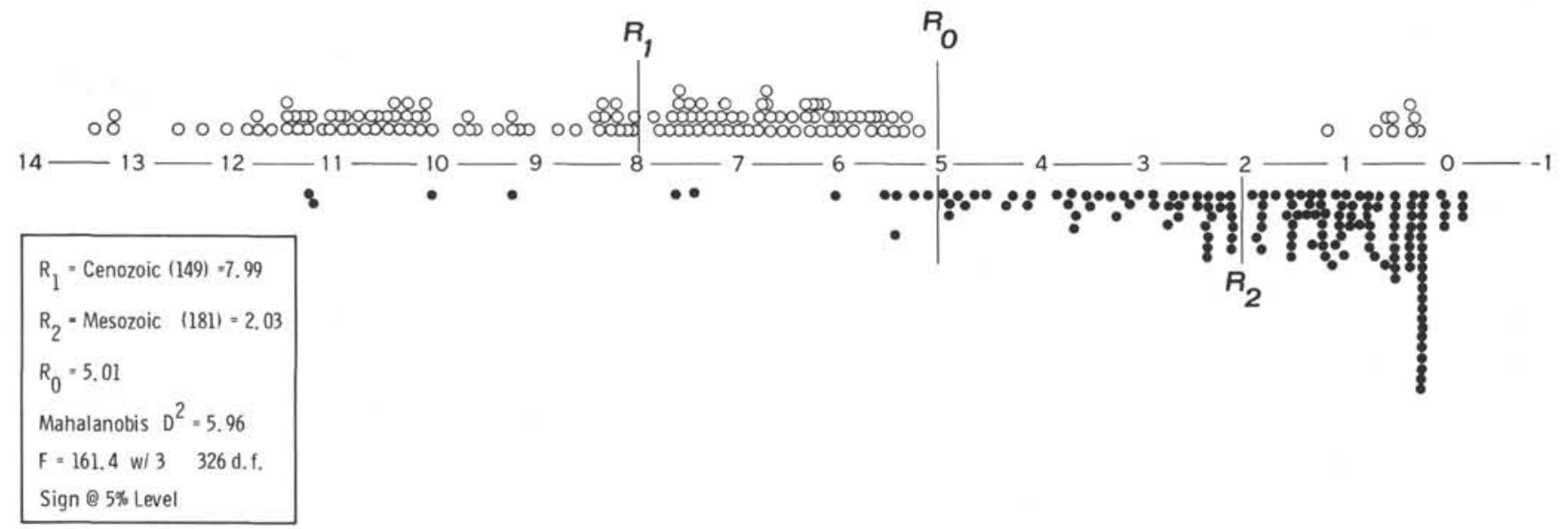

Figure 15. Projection of the discriminant scores of all Mesozoic and Cenozoic sediments of the eastern Indian Ocean (including the Timor Trough) based on the same parameters in Figure 14. Open circles represent Cenozoic samples, solid circles Mesozoic samples. 
periods of carbonate enrichment interspersed with times of carbonate impoverishment.

Even more marked changes evidently occurred between deposition of the moderately calcareous Aptian sediments and the highly calcareous Cenozoic sediments. The flood of carbonate material in the Cenozoic suggests a great increase in production by pelagic organisms coupled with better preservation of carbonate sediments. A period of northward movement of the Australian plate followed the split with Antarctica in the Eocene (McKenzie and Sclater, 1971). Consequently, latitudinal changes and attendant temperature changes may have been in part responsible for this influx of carbonate. However, the fact that this influx occurred at the same time over $25^{\circ}$ of latitude suggests that this is not the only factor. With the development of a southern ocean there were undoubtedly marked changes in the pattern of oceanic circulation which may also have influenced carbonate production and deposition. However, the precise reason for the Cenozoic incoming of carbonate is not known for, in addition to climatic changes, changes in the morphology of the slope, and even increases in seismicity could presumably affect the amount of calcareous material being deposited on the abyssal plains.

\section{UNCONFORMITY BETWEEN CENOZOIC AND MESOZOIC ABYSSAL PLAIN SEDIMENTS}

Seismic profiles indicate that the acoustically layered and transparent sequences beneath the abyssal plains are separated by an angular unconformity (Figure 2). The transparent sequence forms a layer of relatively uniform thickness draped evenly over basement topography. The acoustically layered sediments are horizontally bedded and vary considerably in thickness, filling low areas on the surface of the transparent layer and pinching out against high areas. Dating of the

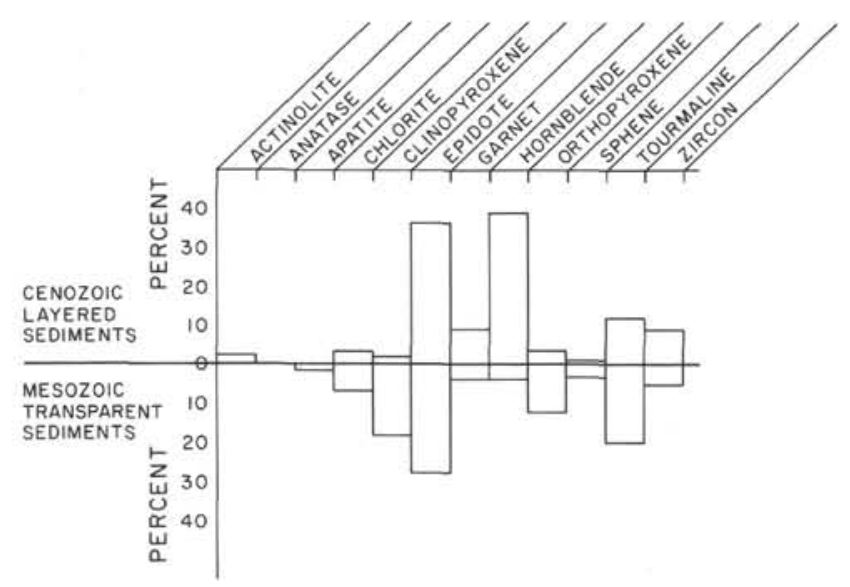

Figure 16. Comparison of heavy mineral assemblages of Mesozoic and Cenozoic abyssal plain sediments of the eastern Indian Ocean. sediments above and below the unconformity indicates that the flat-lying, acoustically layered sediments are Cenozoic whereas the transparent sequence is Mesozoic. The oldest cored sediment above the unconformity is lower Paleocene and the youngest sediment below is Maestrichtian.

The Mesozoic sediments are chiefly fine-grained clays and claystones presumably formed by pelagic deposition in an abyssal environment. Such deposition should produce a uniform layer of clay draped over the basement topography. In contrast, the Cenozoic sediments consist chiefly of nannofossil and foraminiferal oozes containing evidence of deposition by mass transport. Although deposited in an abyssal environment, these oozes contain abundant shallow-water foraminifers and have numerous graded sequences, suggesting that the sediments originally formed in a shallow-water shelf environment and later were transported to the abyssal plains. There they were deposited in horizontal beds in low areas on the sea floor, gradually filling these areas and overlapping basement highs draped with Mesozoic pelagic clays. Hence, the angular unconformity between the two sequences is seen as a change from predominantly pelagic deposition of clay to predominantly mass transport deposition of calcareous ooze.

In addition to the angular unconformity between the acoustically layered and transparent sequences, there is a depositional hiatus in the Upper Cretaceous. Upper Cretaceous sediments are completely absent at Sites 259 and 263 and are only poorly represented at Sites 260 and 261 (Figure 18). This scarcity of Upper Cretaceous sediments on the abyssal plains is puzzling because deposits of this age are present on the western Australian continental shelf (Veevers and Johnstone, this volume), on the Naturaliste Plateau (DSDP Sites 258 and 264) (Luyendyk et al., 1973). This gap in the record must be the result of either erosion or nondeposition. Erosion at the top of the Cretaceous early in the Cenozoic seems unlikely for several reasons, particularly the selectivity of the level to which erosion apparently extended and the presence of small quantities of Maestrichtian and Coniacian sediments at Sites 260 and 261. Furthermore, if post-Cretaceous erosion was responsible for the hiatus, the sediments would have accumulated over a period of approximately 35 m.y. before erosion commenced. Under these conditions at least some of the sediment column would probably have become sufficiently indurated to resist erosion.

If the Upper Cretaceous hiatus reflects nondeposition, it is necessary to postulate a mechanism which would allow sedimentation to occur in the shallow portions of the Cretaceous sea and yet prevent or greatly reduce deposition on the abyssal plains. Deep geostrophic or contour currents sweeping around the outer edge of the abyssal plains appear to be the most likely mechanism. Such currents probably would not have been strong enough to erode sediment, but could easily have prevented deposition of fine pelagic material. Presumably, with the separation of Australia and Antarctica in the Eocene, new circulation patterns were established and the intensity of the bottom currents 


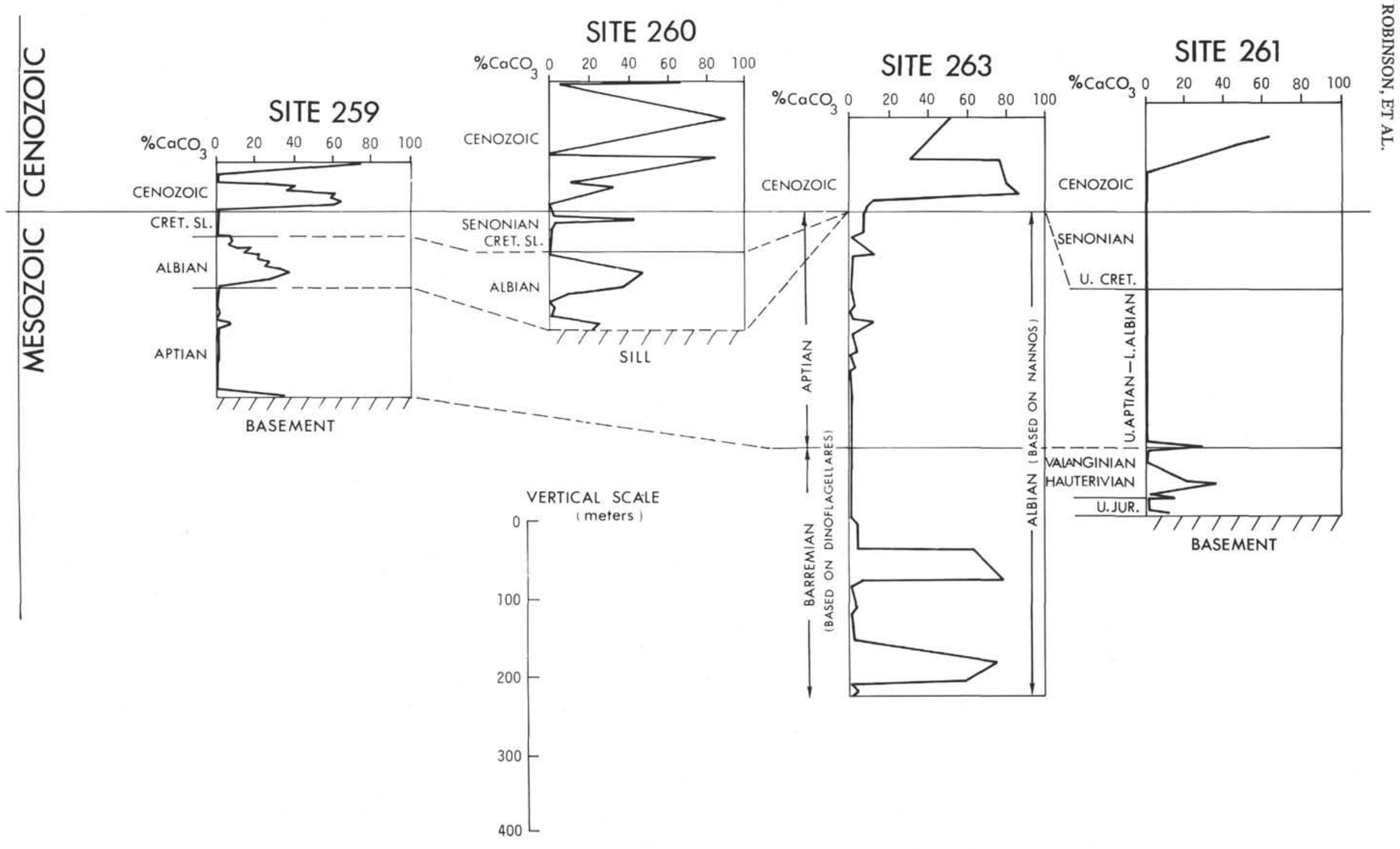

Figure 17..Distribution of $\mathrm{CaCO}_{3}$ with depth in abyssal plain sediments of the eastern Indian Ocean. 
Percent $\mathrm{CaCO}_{3}$
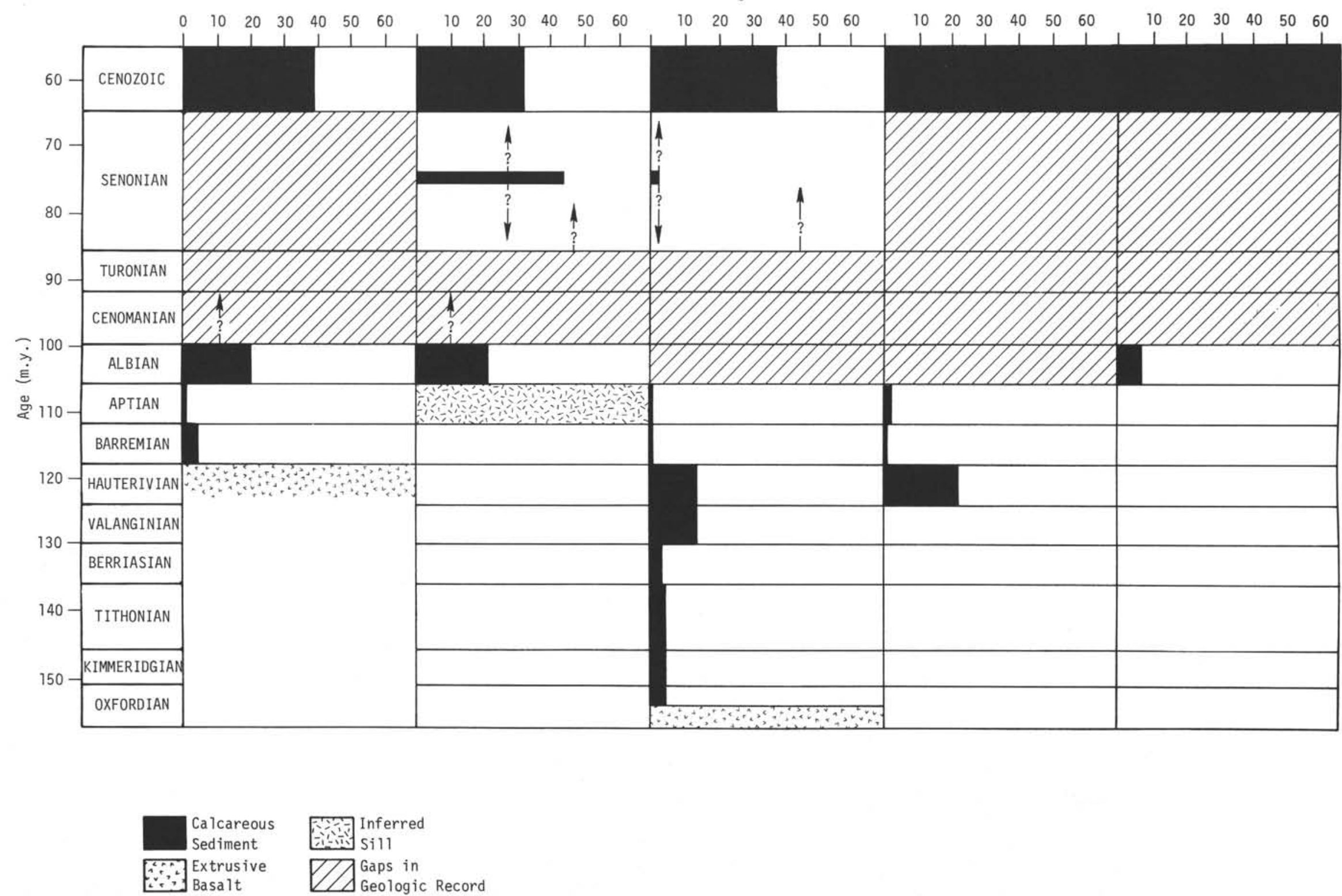
diminished. Production of abundant carbonate material occurred in shallow-water shelf areas and this material was carried into the abyssal environments by mass transport mechanisms.

\section{CONCLUSIONS}

Abyssal sediments in the eastern Indian Ocean can be divided into two distinct units separated by an angular unconformity: a lower sequence of acoustically transparent sediment ranging in age from Upper Jurassic to Upper Cretaceous and an upper, layered sequence of Cenozoic age. The transparent layer is draped over basaltic basement and is relatively uniform in thickness; the layered sequence is horizontally bedded and highly variable in thickness, filling low areas on the surface of the transparent layer and pinching out against highs.

The transparent layer consists chiefly of dark gray clay and siliceous claystone with lesser amounts of zeolitic clay and nannofossil ooze. These sediments are thickest near the edge of the Australian continent and thin westward, apparently pinching out near the western margin of the Wharton Basin between DSDP Sites 211 and 213. They are believed to be the result of pelagic sedimentation at abyssal depths except at Site 263, where the silty kaolinitic clays were probably deposited in relatively shallow water. A stagnant, slightly euxinic, environment is suggested by dark colors, abundant pyrite, the general absence of burrowing organisms, and the impoverished biota of arenaceous foraminifers and radiolarians. Stagnation at the sea floor must have been mild to allow the existence of bottom-dwelling foraminifers, but stronger anaerobic conditions probably prevailed just below the sediment surface. The presence of abundant montmorillonite and zeolite suggests a volcanic origin for many of the clays, either by in situ alteration of volcanic ash or by subaerial weathering of volcanic rocks. High sedimentation rates probably reflect the proximity of the Australian continent.

The acoustically layered sequence consists chiefly of calcareous ooze with lesser zeolitic clay, all of Cenozoic age. These sediments are lighter colored, much less indurated, and much more calcareous than the Mesozoic sediments. The oozes have abundant shallowwater foraminifers and many contain graded sequences. The calcareous sediments are believed to have formed on the relatively shallow shelf areas around the Australian continental margin and to have been carried into the abyssal plains by mass transport processes. This accounts for the deposition of large quantities of calcareous sediment at abyssal depths below the normal carbonate compensation level.

Distribution of carbonate-rich sediments in the abyssal plain sequences appears to be temporally controlled and is probably due primarily to climatic fluctuations. The great influx of carbonate sediments in the Cenozoic probably reflects changes in climate and oceanic circulation associated with the separation of Australia from Antarctica in the Eocene.

The angular unconformity between Mesozoic and Cenozoic abyssal plain sediments reflects a change from predominantly pelagic deposition of clay in the
Mesozoic to predominantly mass transport deposition of calcareous ooze in the Cenozoic. Early pelagic sedimentation produced a uniform layer of clay draped over basaltic basement, and later mass transport deposition of calcareous ooze produced a sequence of flatlying sediments ponded in low areas on the surface of the transparent layer. The hiatus in the Upper Cretaceous reflects nondeposition during this time, probably due to bottom currents sweeping across the abyssal plains.

The Timor Trough formed in the Pliocene with a rapid downfolding of shallow-water calcarenites. The downwarped trough was then filled during the late Pliocene and Quaternary with nannofossil and foraminiferal ooze. The high sedimentation rate and the presence of graded beds in this sequence suggest that the trough was filled by slumping from the margins as well as by pelagic sedimentation. Very high salinities in the interstitial waters from sediments near the base of the sequence suggest the presence of a salt body at some depth below the bottom of the cored sequence.

\section{ACKNOWLEDGMENTS}

P. A. Thayer, J. Hostettler, and S. Smith provided the grainsize data used in this paper; B. McKnight the heavy mineral analyses; and the Analytical Chemistry Section of the Australian Mineral Development Laboratories the chemical analyses. X-ray diffraction analyses are by the Deep Sea Drilling Project X-ray laboratory at Riverside, California. P. A. Thayer acknowledges support for this project from the Program in Marine Sciences Research of the University of North Carolina at Wilmington. P. J. Cook publishes with the permission of the Director, Bureau of Mineral Resources, Canberra.

\section{REFERENCES}

Beck, R. H. and Lehner, P., 1974. Oceans, new frontiers in exploration: Am. Assoc. Petrol. Geol. Bull., v. 58, p. 376-395.

Carozzi, A. V., 1960. Microscopic sedimentary petrography: New York (John Wiley).

Davies, T. A. and Supko, P. R., 1973. Oceanic sediments and their diagenesis: some examples from deep-sea drilling: J. Sediment. Petrol., v. 43, p. 381-390.

Davis, J. C., 1973. Statistics and data analysis in geology: New York (John Wiley).

Ernst, W. G. and Calvert, S. E., 1969. An experimental study of the recrystallization of porcelanite and its bearing on the origin of some bedded cherts: Am. J. Sci., v. 267-A, p. 114133.

Folk, R. L. and Ward, W. C., 1957. Brazos River bar, a study of the significance of grain size parameters: J. Sediment. Petrol., v. 27, p. 3-27.

Garrels, R. M. and MacKenzie, F. T., 1971. Evolution of sedimentary rocks: New York (W. W. Norton and Co.).

Hathaway, J. C. and Sachs, P. L., 1965. Sepiolite and clinoptilolite from the mid-Atlantic Ridge: Am. Mineralogist, v. 50 , p. $852-867$.

Hayes, D. E., Frakes, L. A., Barrett, P., Burns, D. A., Chen, P.- H., Ford, A. B., Kaneps, A. G., Kemp, E. M., McCollum, D. W., Piper, D. J. W., Wall, R. E., and Webb, P. N., 1973. Leg 28 deep-sea drilling in the southern ocean: Geotimes, v. 18, p. 19-24. 
Luyendyk, B. P., Davies, T. A., Rodolfo, K. S., Kempe, D. R. C., McKelvey, B. C., Leidy, R. D., Horvath, G. J., Hyndman, R. D., Theirstein, H. R., Boltovskoy, E., and Doyle, P., 1973. Across the southern Indian Ocean aboard Glomar Challenger: Geotimes, v. 18, p. 16-19.

McKenzie, D. P. and Sclater, J. G., 1971. The evolution of the Indian Ocean since the Late Cretaceous: Roy. Astron. Soc. Geophys. J., v. 25, p. 437-528.

Pettijohn, F. J., 1957. Sedimentary rocks: 2nd ed, New York (Harper and Row).

Sabins, F. F., 1962. Grains of detrital, secondary and primary dolomite from Cretaceous strata of the western interior: Geol. Soc. Am. Bull., v. 73, p. 1183-1196.

van der Lingen, G. J., 1973. Ichnofossils in deep-sea cores from the southwest Pacific. In Burns, R. E., Andrews, J. E., et al., Initial Reports of the Deep Sea Drilling Project, Volume 21: Washington (U.S. Government Printing Office), p. 693-700.

Veevers, J. J., Windisch, C. C., and Falvey, D. A., in press. Timor Trough-a modern fore deep: Geol. Soc. Am. Bull.

von der Borch, C. C., Sclater, J. G., et al., 1974. Initial Reports of the Deep Sea Drilling Project, Volume 22: Washington (U.S. Government Printing Office).

von Rad, U. and Rösch, H., 1972. Mineralogy and origin of clay minerals, silica and authigenic silicates in Leg 14 sediments. In Hayes, D. E., Pimm, A. C., et al., Initial Reports of the Deep Sea Drilling Project, Volume 14: Washington (U.S. Government Printing Office), p. $727-$ 752. 
PLATE 1

Photomicrographs of Cretaceous sediments from Leg 27.

Figure 1 Sample $259-9-3,74-76 \mathrm{~cm}$. Thinly laminated, stiff zeolite clay. Spumellarian radiolarians (S) are lined with clinoptilolite and set in a matrix of palygorskite, montmorillonite, quartz, and mica. Wavy laminae are of uneven thickness. Dark laminae probably contain more organic matter than lighter ones. Crossed nicols. Scale bar $=$ $250 \mu$.

Figure 2 Sample 259-9-3, 74-76 cm. Enlarged view of 1. Spumellarian radiolarians have been altered to generally structureless spheres and lenses of clinoptilolite. Plane-polarized light. Scale bar $=$ $100 \mu$.

Figure 3 Sample 261-9-4, 67-69 $\mathrm{cm}$. Structureless spumellarian radiolarian altered to clinoptilolite. Sediment is zeolite-rich clay. Dark matrix consists of mica, palygorskite, montmorillonite, cristobalite, quartz, and feldspar. Plane-polarized light. Scale bar $=100 \mu$.

Figure 4 Sample 261-9-4, 67-69 $\mathrm{cm}$. Sheaves of fibrous, length-fast, chalcedonic quartz filling radiolarian mold. Sediment is semilithified zeolite-rich clay. Partially crossed nicols. Scale bar $=100 \mu$.

Figure 5 Sample 263-12-3, 26-29 cm. Rounded, dark green chlorite grain (center), along with angular and subangular quartz grains (Q), set in matrix consisting of montmorillonite, mica, and fine quartz. Plane-polarized light. Scale bar $=250 \mu$.

Figure 6 Sample 263-12-3, 26-29 cm. Semilithified, greenish-black quartz-rich clay. Angular and subangular quartz and rounded opaque $(\mathrm{O})$ mineral grains "float" in matrix of montmorillonite, chlorite, and fine quartz. Crossed nicols. Scale bar $=250 \mu$. 
PLATE 1
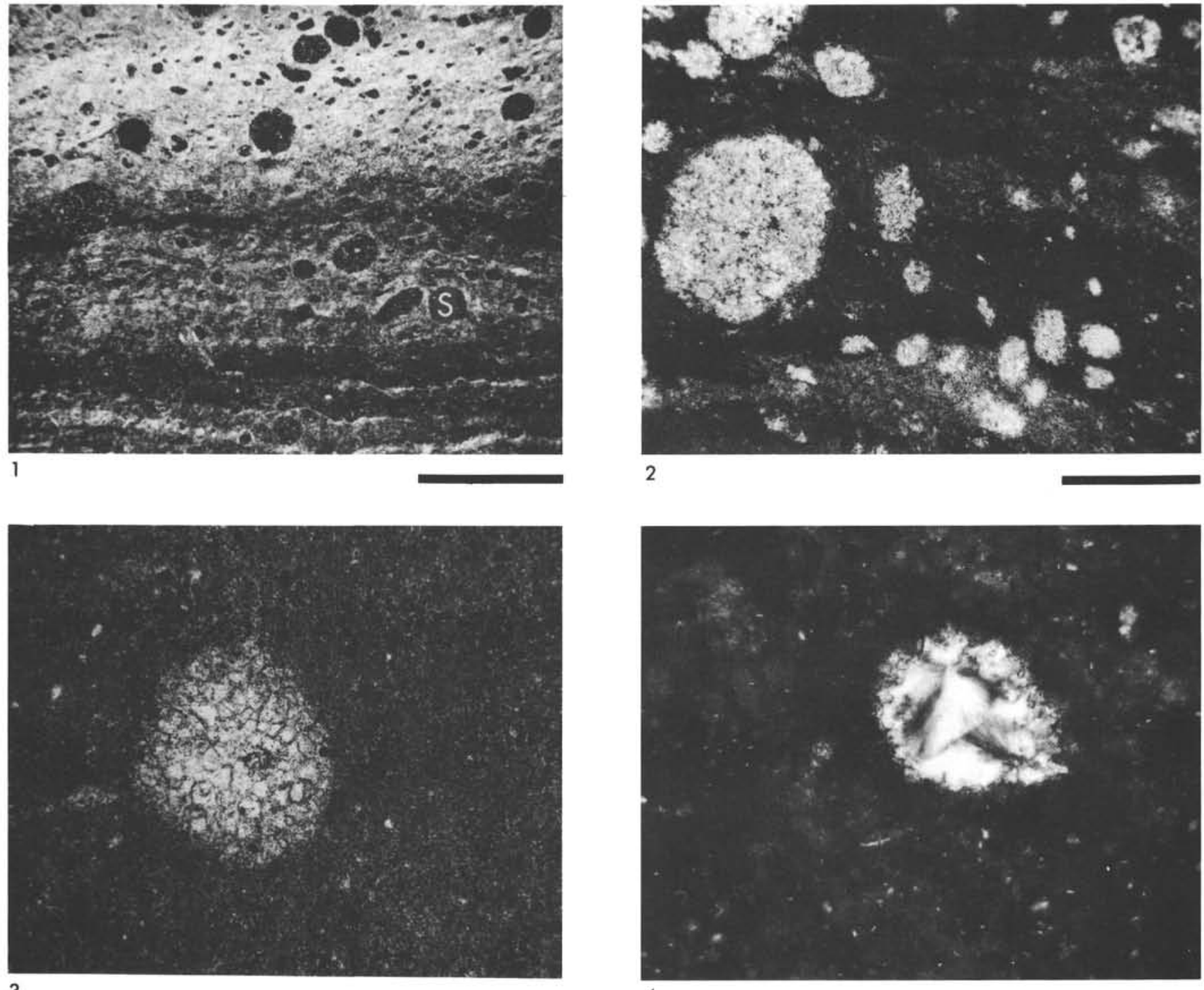

3

4
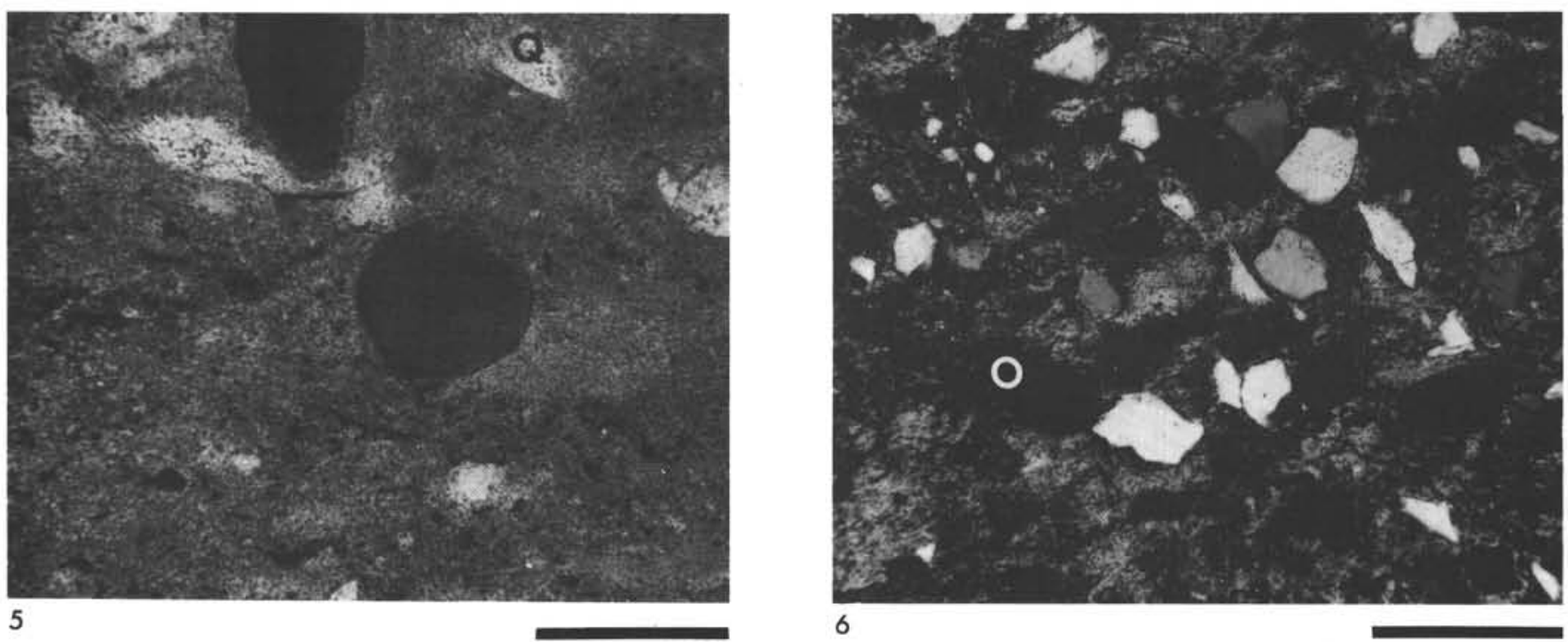
PLATE 2

Photomicrographs of Cretaceous sediments from Leg 27.

Figure 1 Sample 261-25-2, 137-141 cm. Semilithified, dark gray quartz claystone. Sediment consists chiefly of silt size quartz with subordinate mica, opaque minerals, and $\mathrm{K}$-feldspar set in a montmorillonite and chlorite matrix. Plane-polarized light. Scale bar $=250 \mu$.

Figure 2 Sample 263-18-3, 89-94 cm. Semilithified, dark gray, quartz-rich clay. Consists principally of angular silt-size quartz with subordinate mica, Kfeldspar, chlorite, and secondary pyrite. Matrix is montmorillonite, microcrystalline quartz, and fine silt-size micas. Larger mica grains are aligned parallel to bedding. Plane-polarized light. Scale bar $=250 \mu$.

Figure 3 Sample 263-12-3, 26-29 cm. Semilithified, greenish-black quartz-rich claystone. Sand- and silt-size terrigenous grains are chiefly quartz with lesser amounts of mica and $\mathrm{K}$-feldspar. Matrix is montmorillonite and clay-size quartz and micas. Note parallel arrangement of sand-size micas in left of photo. Lighter-colored mottled area on right is a diagenetic feature of unknown origin. Colorless grains with high relief are granular aggregates of calcite (C). Plane-polarized light. Scale bar $=250 \mu$.

Figure 4 Sample 259-27-3, 74-76 cm. Stiff, dark greenishgray, cristobalite clay. Dark-colored fractures are due to drilling deformation. Note nodular bedding. Light-colored silt-size grains are quartz. Rounded white area in center right is radiolarian mold (R) filled with length-fast fibrous chalcedony. Structureless matrix is montmorillonite and cristobalite. Plane-polarized light. Scale bar $=250 \mu$.

Figure 5 Sample 261-11-1, 105-115 cm. Radiolarianbearing, dark gray quartz claystone. Tests of spumellarian radiolarians are recrystallized to microcrystalline quartz, and lumens are filled with radiating bundles of fibrous, length-fast chalcedony. Matrix is clay (montmorillonite?) and finely divided quartz and micas. Partiahly crossed nicols. Scale bar $=250 \mu$.

Figure 6 Sample 260-16-1, 130-132 cm. Semilithified, nodular greenish-gray quartz clay. Dark fractures are due to drilling deformation. White, irregularshaped areas are silt-size quartz grains (Q) with overlap of matrix. Dark irregular patches in matrix are iron oxides. Matrix is composed of clay minerals (montmorillonite?) and finely divided quartz and mica. Plane-polarized light. Scale bar $=100 \mu$. 
PLATE 2

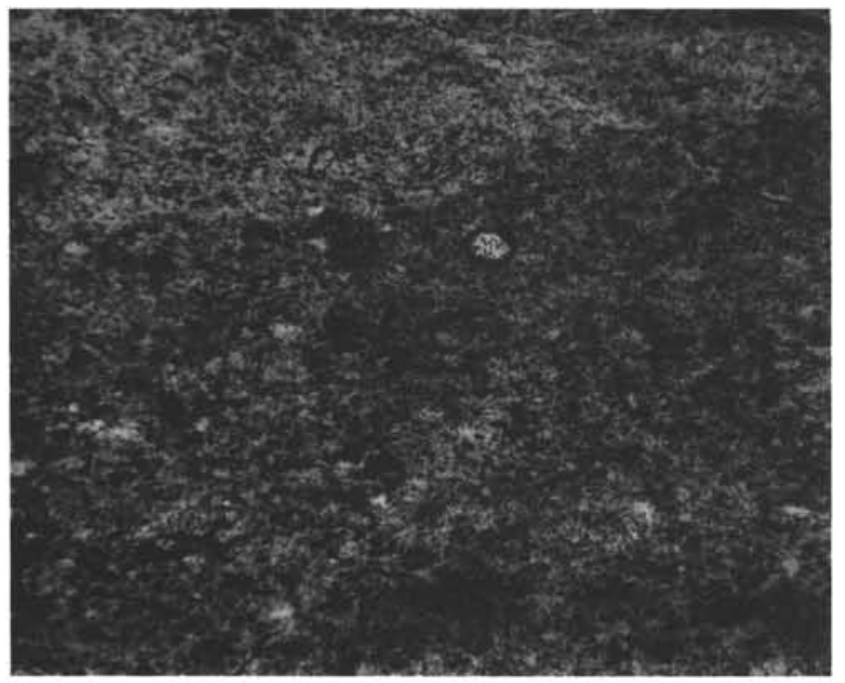

$$
1
$$

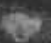

3

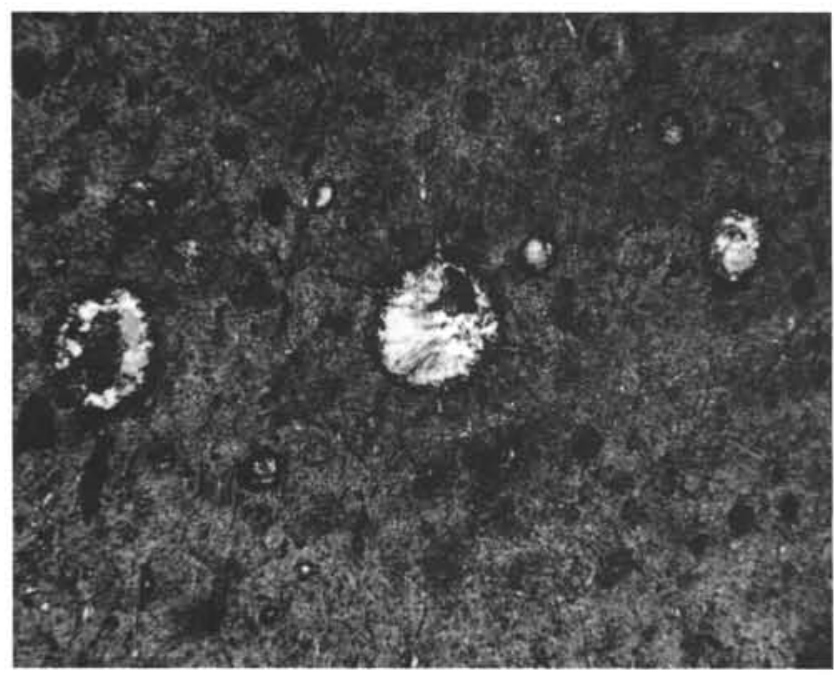

5
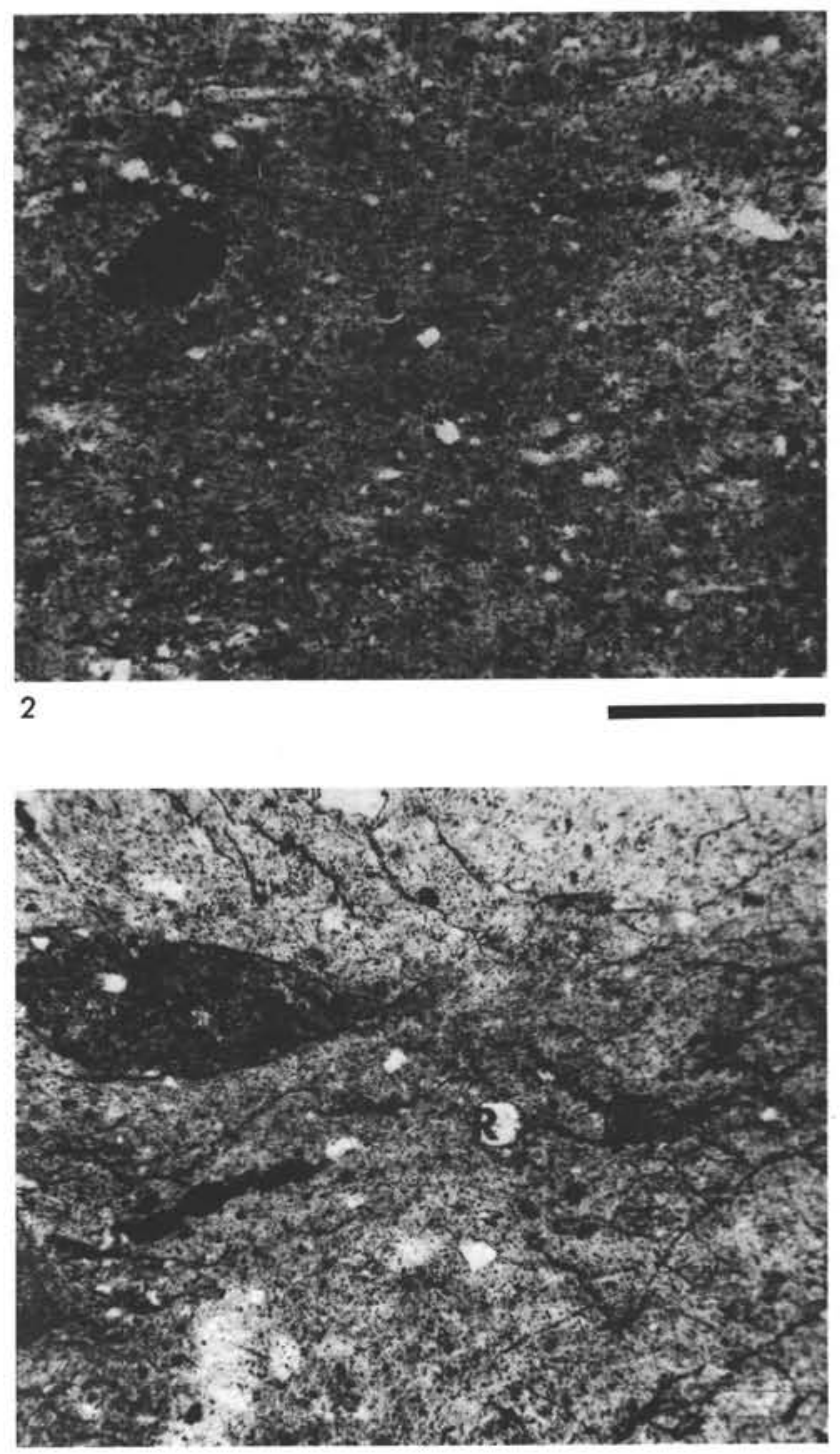

4

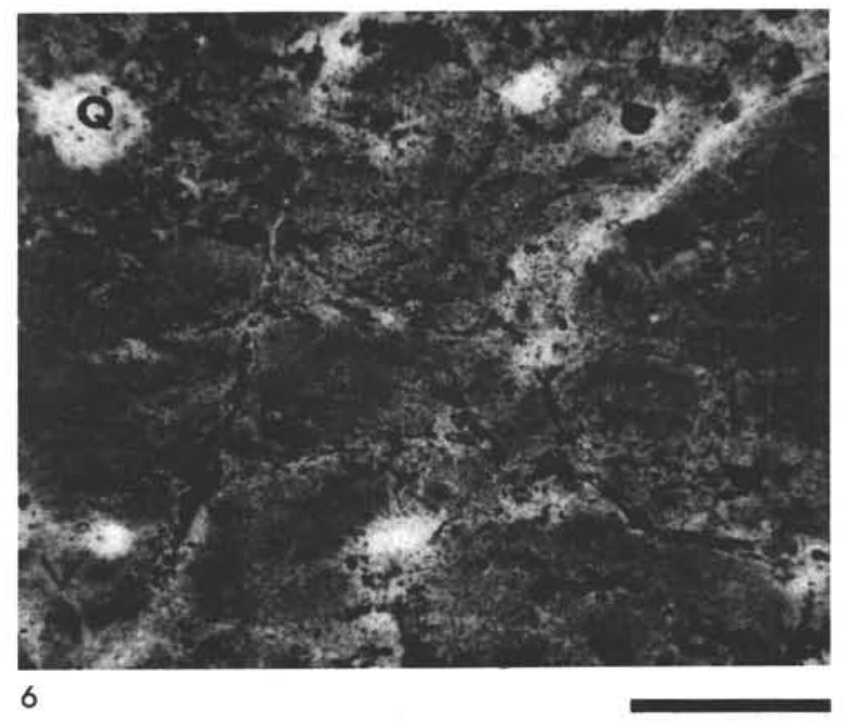




\section{PLATE 3}

Diagnetic features of Cretaceous sediments from Leg 27.

Figure 1 Sample 263-10-3, 88-90 cm. Dolomite nodule. Dark-colored, finely crystalline dolomite is cut by several generations of calcite veins. Large vein on right, which shows crystal enlargement towards the center (to the right), is cut by smaller veins trending from left to right across the photograph. Plane-polarized light. Scale bar $=1 \mathrm{~mm}$.

Figure 2 Sample 263-10-3, 88-90 cm. Enlarged view of A showing enlargement of radiaxial fibrous calcite crystals towards center of vein. Plane-polarized light. Scale bar $=250 \mu$.

Figure 3 Sample 263-14-4, 32-34 cm. Calcite vein in barite nodule. Nodule is from semilithified quartz-rich claystone. Note enlargement of calcite crystals towards center of vein. Crossed nicols. Scale bar = $1 \mathrm{~mm}$.

Figure 4 Sample 263-12-3, 26-29 cm. Semilithified greenishblack quartz-rich claystone. Grains with high relief are secondary granular aggregates of calcite. Plane-polarized light. Scale bar $=250 \mu$.

Figure 5 Sample 263-14-5, 32-34 cm. Yellowish-gray barite nodule. Granular aggregate of anhedral barite crystals which have replaced a quartz-rich clay. Nasselarian radiolarian $(\mathrm{N})$ in center is filled with barite. Other radiolarians ( $R$ ) are completely replaced by barite. Plane-polarized light. Scale bar $=250 \mu$.

Figure 6 Sample 263-16-1, 80-85 cm. Dolomite nodule from semilithified greenish-black quartz-rich claystone. Anhedral and subhedral interlocking dolomite crystals contain abundant dust inclusions. Planepolarized light. Scale bar $=250 \mu$. 


\section{PLATE 3}
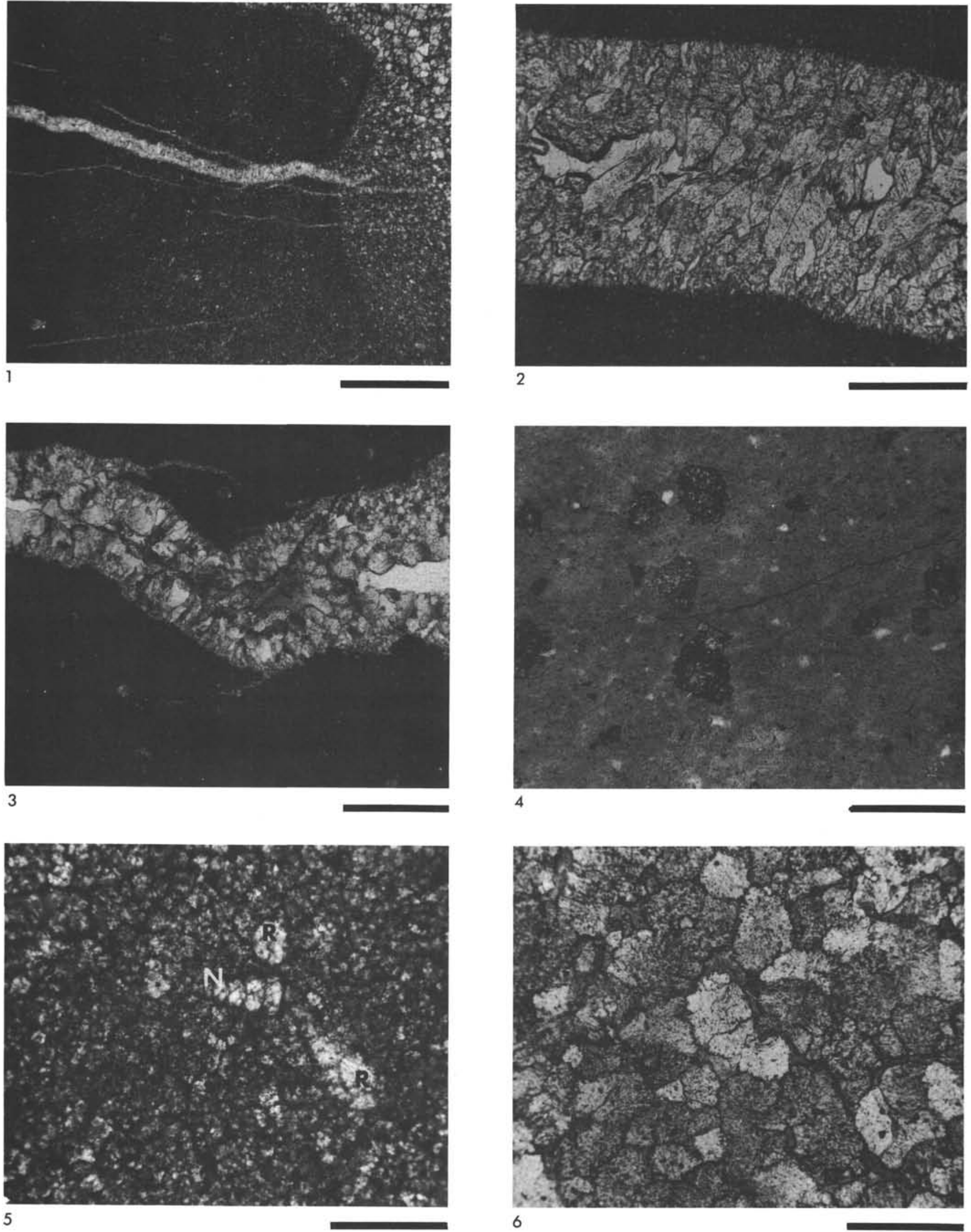


\section{PLATE 4}

Photomicrographs of Cretaceous sediments, Leg 27.

Figure 1 Sample 259-22-2, 48-50 cm. Dusky yellow dolomite nodule from olive-black, stiff cristobalite clay. Most of the dolomite rhombohedrons exhibit curved boundaries. Also note many twin crystals. Plane-polarized light. Scale bar $=100 \mu$.

Figure 2 Sample 263-21-1, 137-142 cm. Light olive-gray dolomite layer in semilithified, olive-black quartzrich clay. Curved dolomite rhombohedrons exhibit zoning with distinct dark cores; they are probably enriched in iron. Plane-polarized light. Scale bar $=1 \mathrm{~mm}$.

Figure 3 Sample 263-24-4, 147-150 cm. Calcite vein in semilithified, olive-black quartz-rich silty clay. Crystals display radiaxial fibrous fabric and become larger toward center of vein (toward bottom of photomicrograph). Plane-polarized light. Scale bar $=1 \mathrm{~mm}$.

Figure 4 Sample 263-24-4, 147-150 cm. Sand-size subrounded kaolinite pellets $(\mathrm{K})$ and lightercolored, high-relief clacite (C). The kaolinite grains consist of a fine mosaic of length-slow crystals. The sediment is brecciated and the fractures filled with a matrix of kaolinite deeply stained by organic matter. Plane-polarized light. Scale bar $=250 \mu$.

Figure 5 Sample 263-28, CC. Calcite-cemented kaolinitic sandstone. Rounded light green kaolinite (K) pellets greatly resemble glauconite grains. Subangular terrigenous grains of quartz (Q) are also present. Both are cemented by sparry calcite. Plane-polarized light. Scale bar $=250 \mu$.

Figure 6 Sample 263-28, CC. Calcite-cemented kaolinitic sandstone. View shows euhedral sparry calcite crystals (end of arrow) that have grown out from kaolinite pellet into interpellet void. All void space is filled with sparry calcite. Plane-polarized light. Scale bar $=200 \mu$. 
PLATE 4
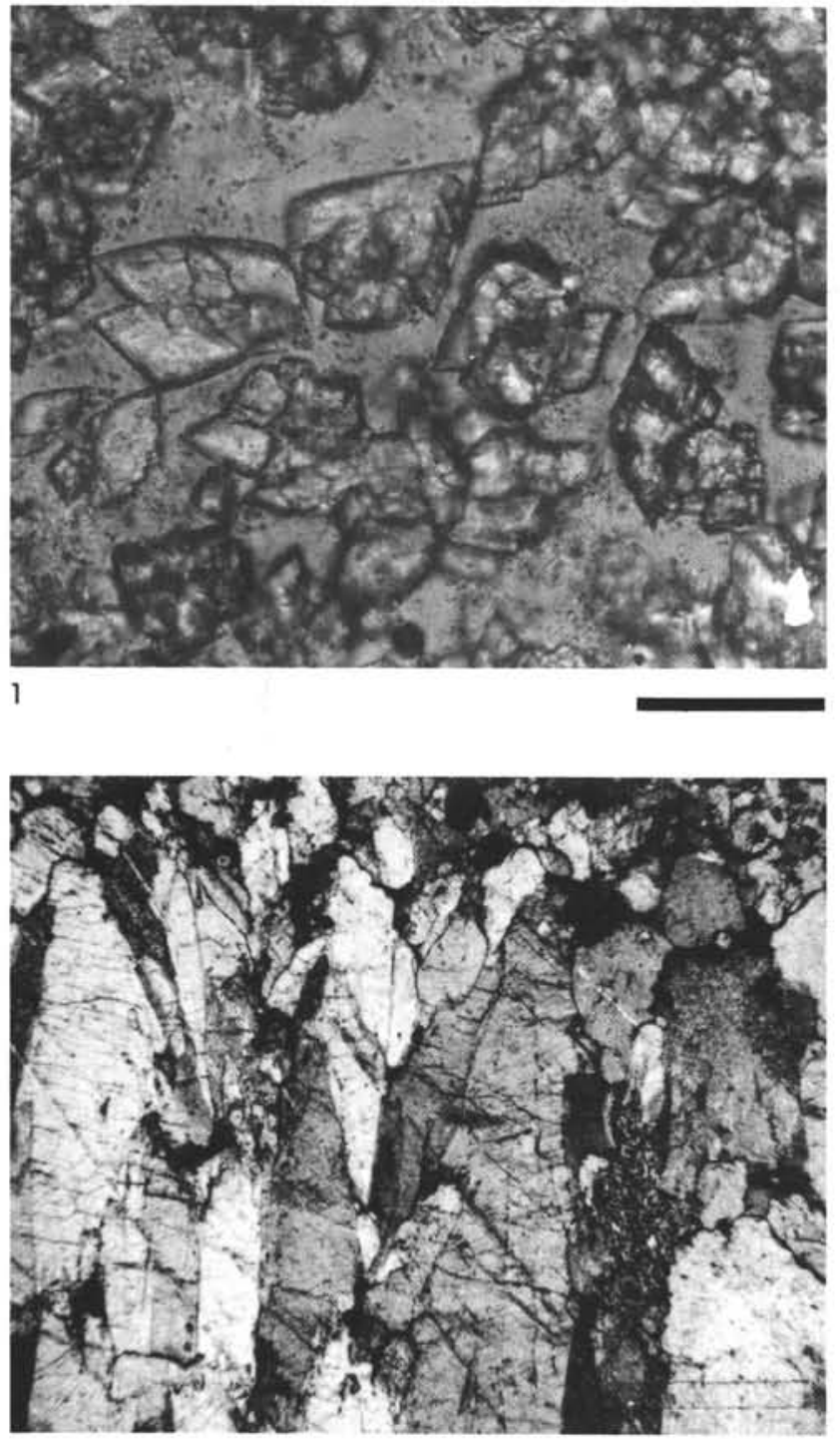

3

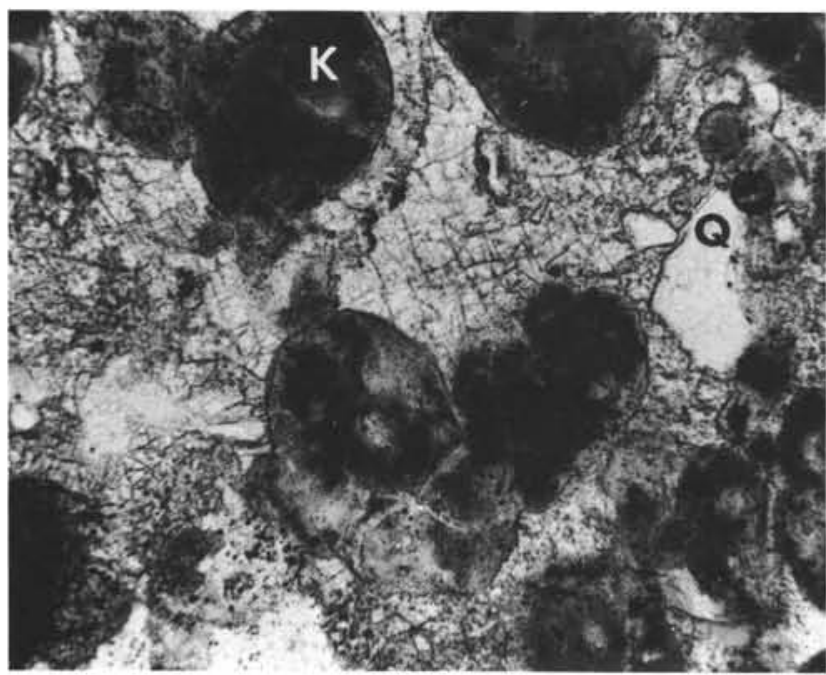

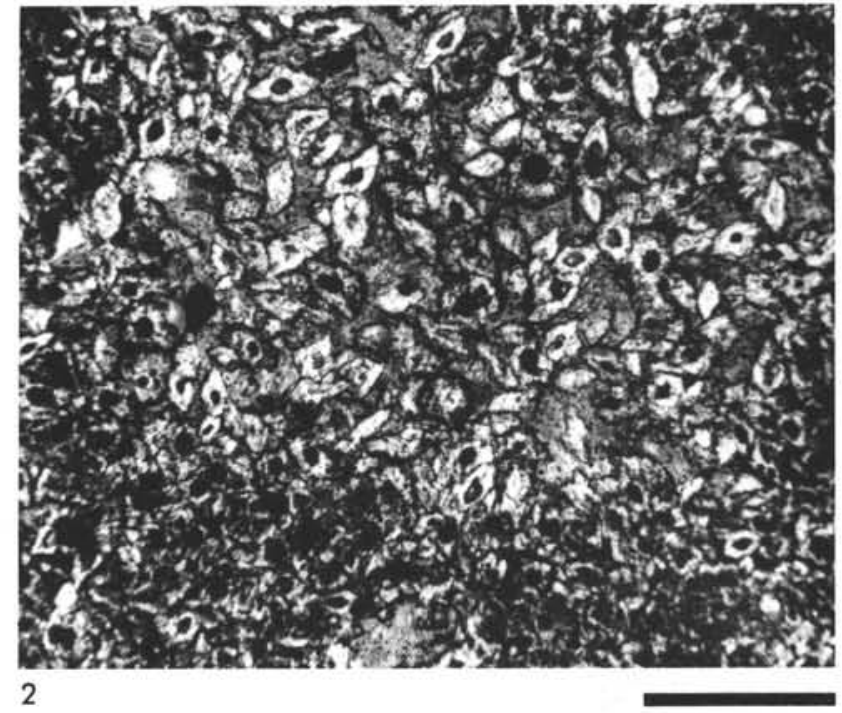
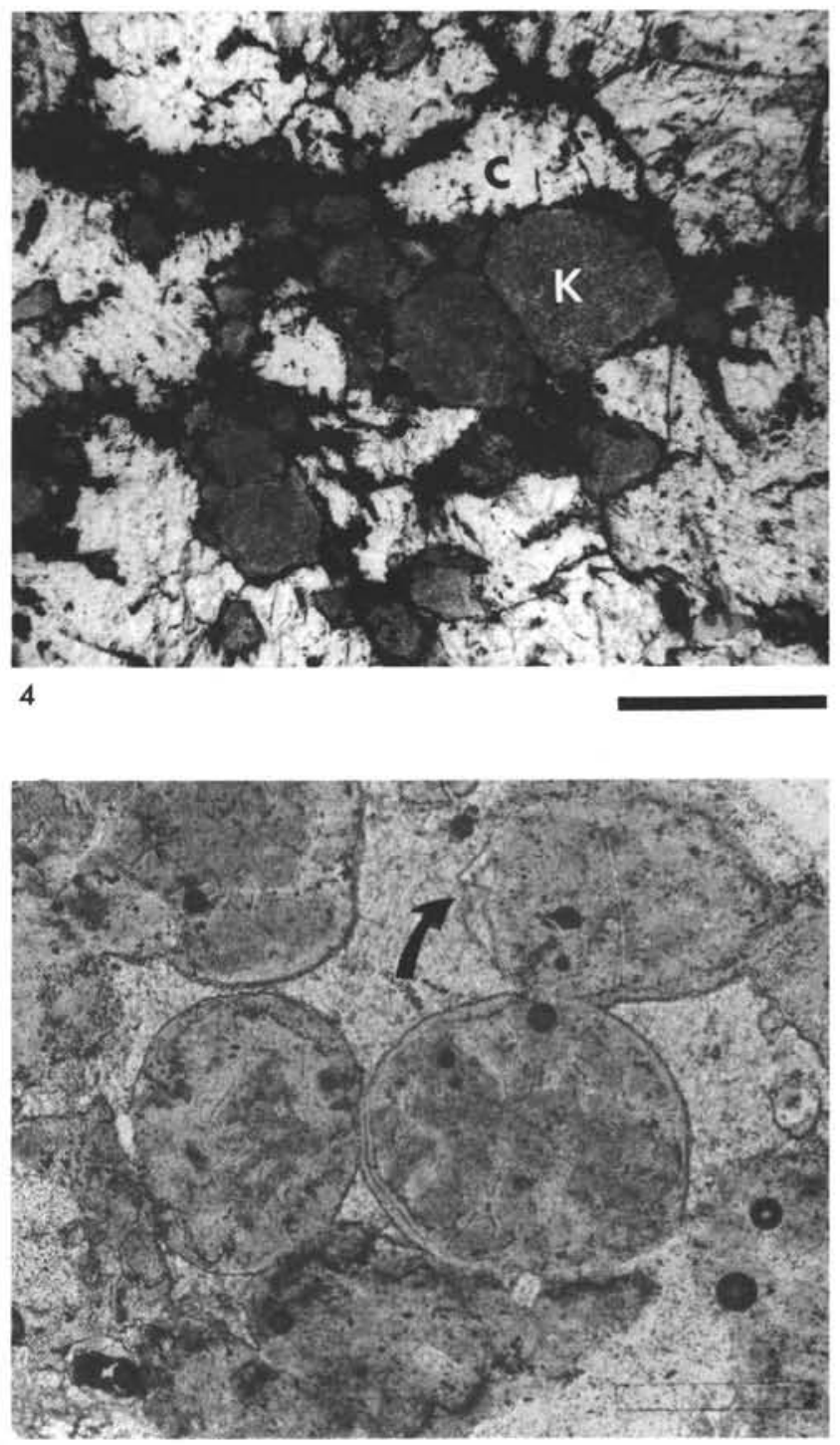

6 


\section{PLATE 5}

Photomicrographs of Cenozoic sediments from Leg 27.

Figure 1 Sample 262-21-1, 99-101 cm. Grayish-olive, foram-bearing, quartz-rich nanno ooze. Silt and sand-size grains of quartz, foraminifers, radiolarians, and diatoms are set in darker-colored nannoplankton matrix. Framboids of pyrite partially fill foraminifer chambers and also replace matrix. Plane-polarized light. Scale bar $=250 \mu$.

Figure 2 Sample 262-36-3, 74-76 cm. Stiff, grayish-olive foram-rich nanno ooze. Planktonic foraminifers, along with some quartz and minor carbonate fragments, are set in darker-colored nannoplankton matrix. Plane-polarized light. Scale bar $=250 \mu$.

Figure 3 Sample 260-2-3, 3-5 cm. Soft, light brown, nannorich foram ooze. Many of the grain-supported planktonic foraminifers are filled with nannoplankton micrite. Note high primary interforam porosity. Plane-polarized light. Scale bar $=250 \mu$.

Figure 4 Sample 262-29-3, 74-76 cm. Stiff, grayish-olive foram-rich nanno ooze. Planktonic foraminifers are set in nannoplankton micrite. Small opaque grains are secondary pyrite. Plane-polarized light. Scale bar $=250 \mu$.

Figure 5 Sample 263-2-3, 68-70 cm. Soft, greenish-gray detrital foram nanno ooze. Whole and broken planktonic foraminifers are set in dark nannoplankton matrix. Framboidal pyrite partially fills chambers of several foraminifers. Plane-polarized light. Scale bar $=250 \mu$.

Figure 6 Sample 263-2-1, 139-141 cm. Soft, greenish-gray, quartz-bearing foram nanno ooze. Planktonic foraminifers, along with terrigenous quartz $(Q)$, are set in a micrite matrix composed of coccoliths. Virtually all intraforam pore space has been filled with micrite. Plane-polarized light. Scale bar $=$ $250 \mu$. 
PLATE 5

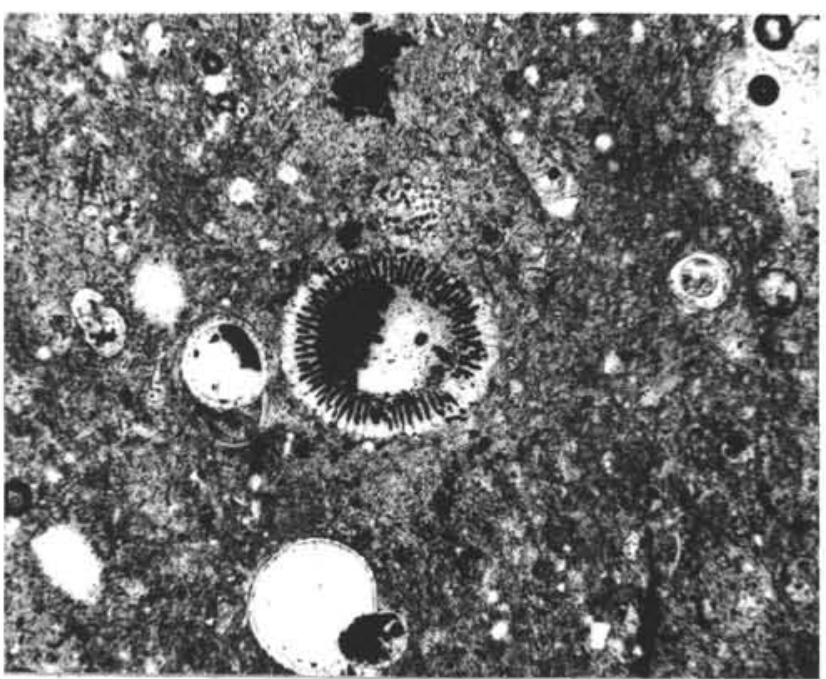

1

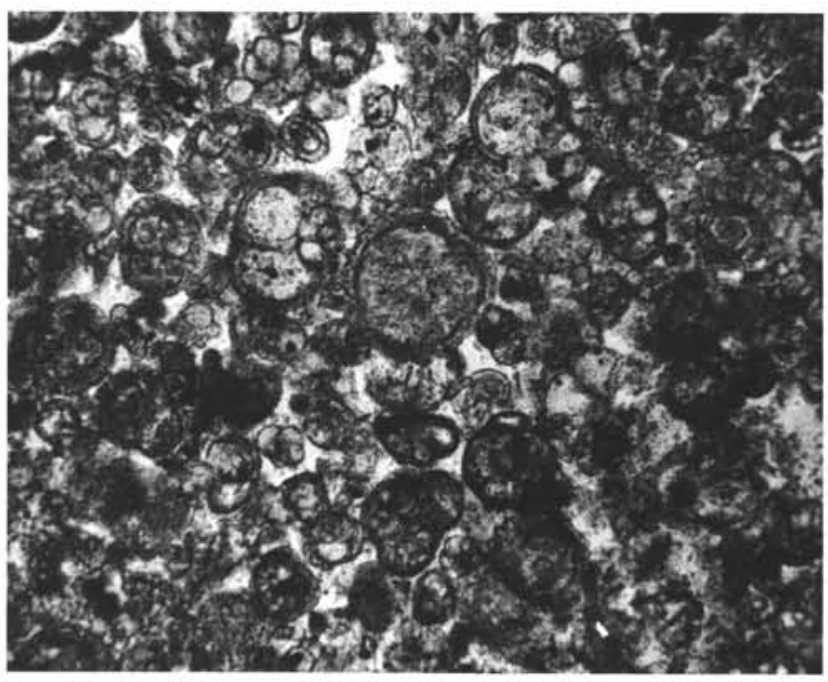

3

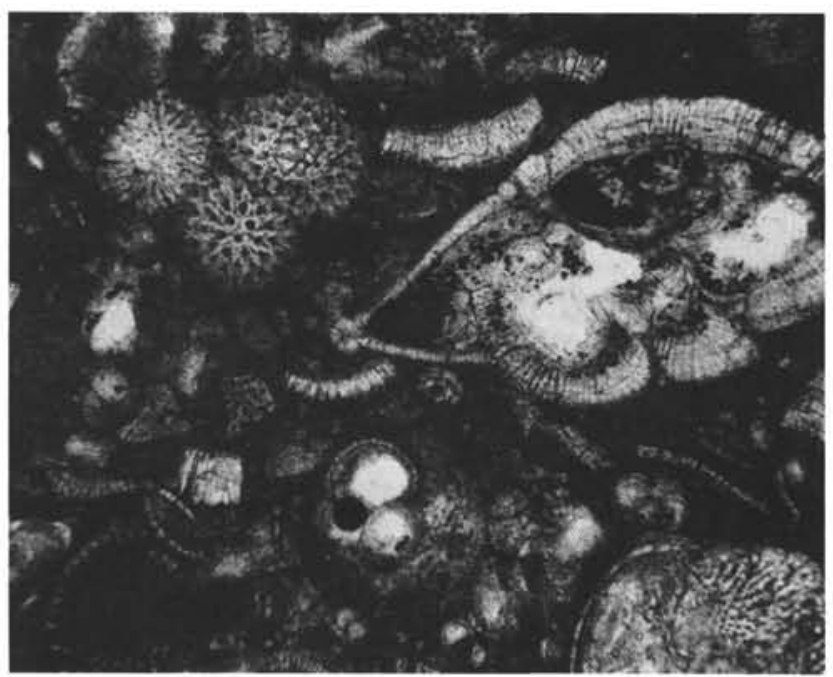

5
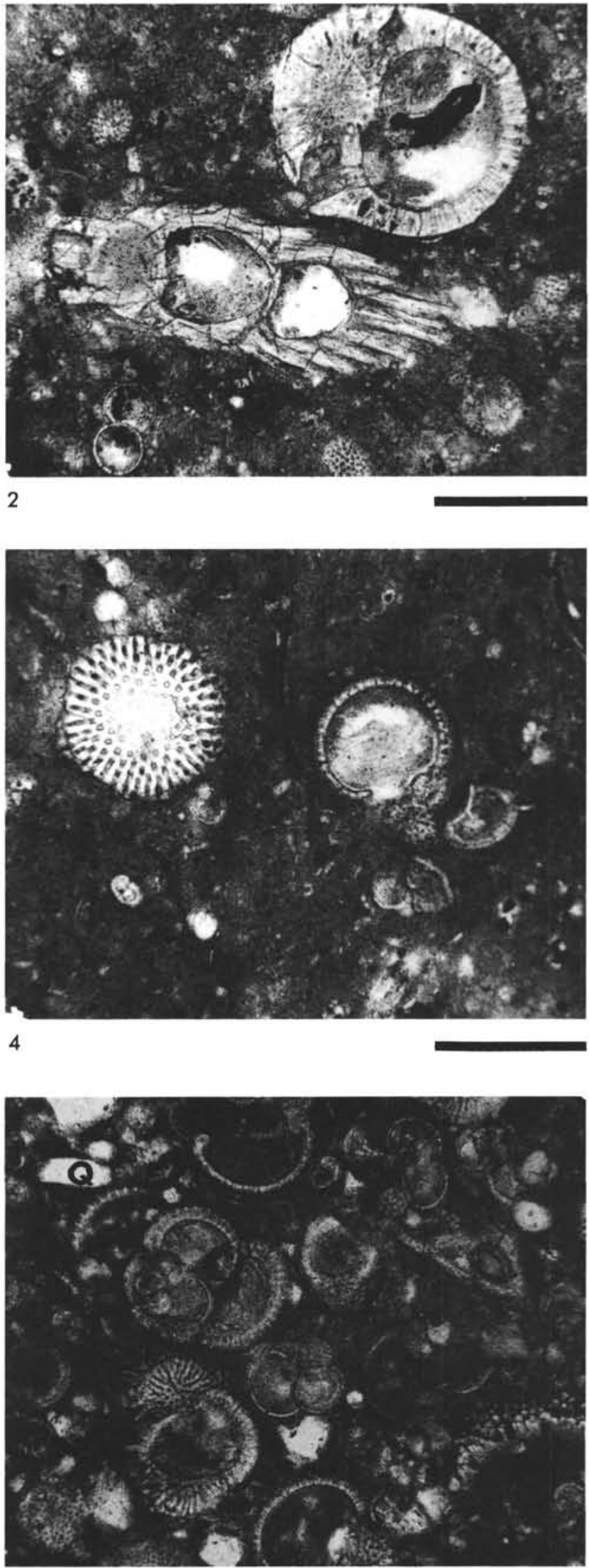

6 
PLATE 6

Photomicrographs of Cenozoic sediments from Leg 27.

Figure 1 Sample 259-4-4, 29-31 cm. Stiff, moderate yellowish-brown zeolite silty clay. Sand-size quartz grain displays prominent marginal embayments, possibly indicative of volcanic origin. Matrix consists of montmorillonite, nannoplankton, mica, and zeolites (clinoptilolite and phillipsite). Plane-polarized light. Scale bar $=$ $100 \mu$.

Figure 2 Sample 262-27-4, 0-6 cm. Stiff, grayish-olive foram-bearing, clay-rich nanno ooze. Dark diagenetic halos around planktonic foraminifer and skeletal fragments (right) are possibly due to reduction of ferric to ferrous iron by organic matter. Lighter-colored matrix is composed chiefly of nannoplankton with subordinate quartz, mica, and montmorillonite. Plane-polarized light. Scale bar $=300 \mu$.

Figure 3 Sample 262-4-1, 90-92 cm. Stiff, grayish-olive micarb-rich clay nanno ooze. Consists of silt- and sand-size micarb fragments (M), radiolarians, foraminifers, sponge spicules (S), and mica set in clay (montmorillonite and kaolinite) and nannoplankton matrix. Plane-polarized light. Scale bar $=250 \mu$.

Figure 4 Sample 262-36-3, 74-76 cm. Stiff, grayish-olive foram-rich clay nanno ooze. Sand- and silt-size foraminifers, quartz, and micarb fragments are set in a clay and nannoplankton matrix. Pyrite partially fills foraminifer in center and also occurs as irregular-shaped grains disseminated throughout the matrix. Plane-polarized light. Scale bar = $250 \mu$.

Figure 5 Sample 262-15-3, 74-76 cm. Stiff, grayish-olive rad-rich nanno ooze. Consists of silt- and sandsize radiolarians, micarb fragments, foraminifers, quartz, plagioclase, mica, and sponge spicules set in a clay (montmorillonite and kaolinite) and nannoplankton matrix. Note large euhedral biotite grain in center. Plane-polarized light. Scale bar $=100 \mu$.

Figure 6 Sample 262-1-2, 104-106 cm. Soft, grayish-olive, sponge spicule and rad-bearing, foram-rich nanno ooze. Sand- and silt-size forams, radiolarians, carbonate fragments, sponge spicules, and quartz are set in a dark clay and nannoplankton matrix. Black, irregular-shaped grains are pyrite. Planepolarized light. Scale bar $=250 \mu$. 
PLATE 6

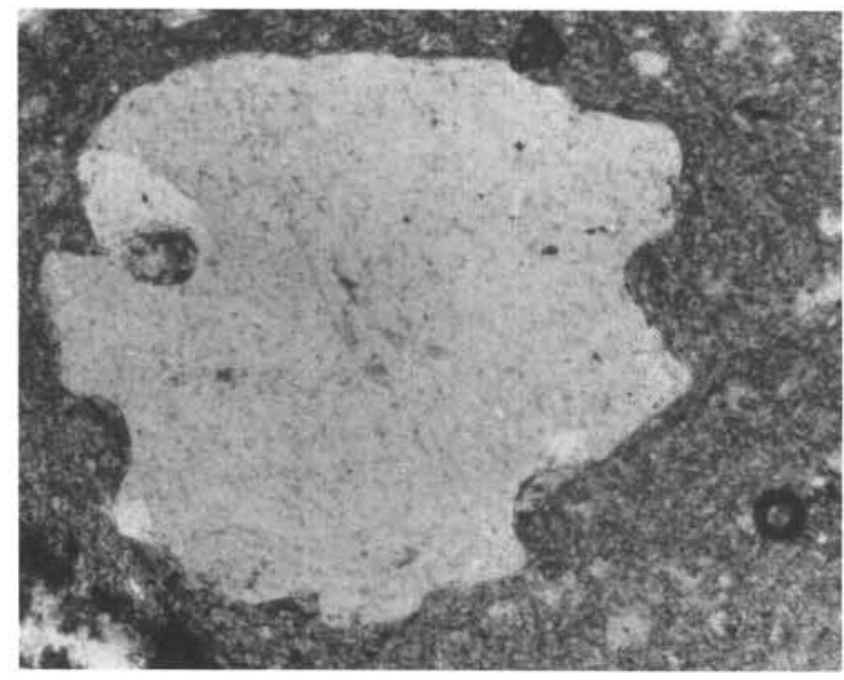

1

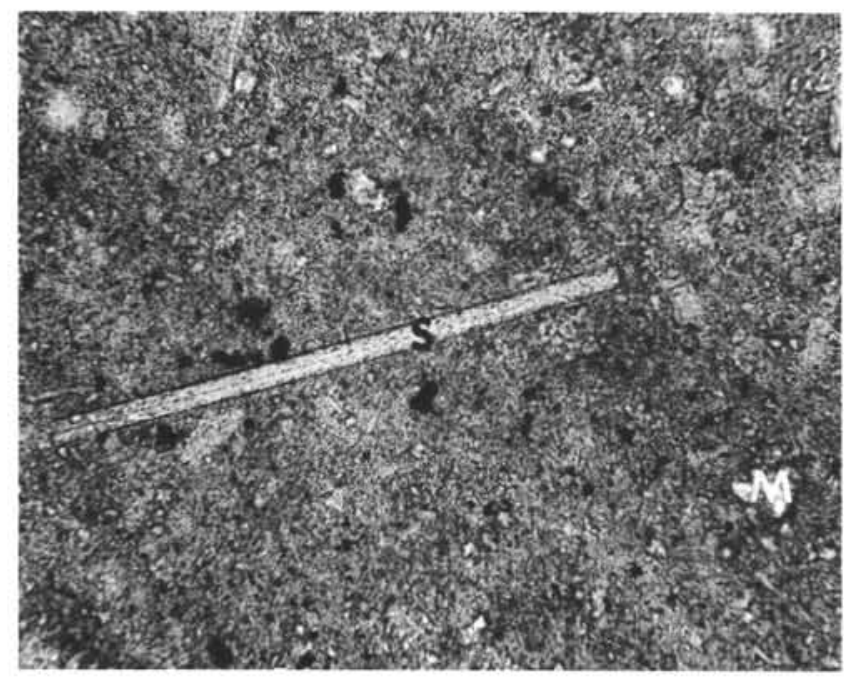

3

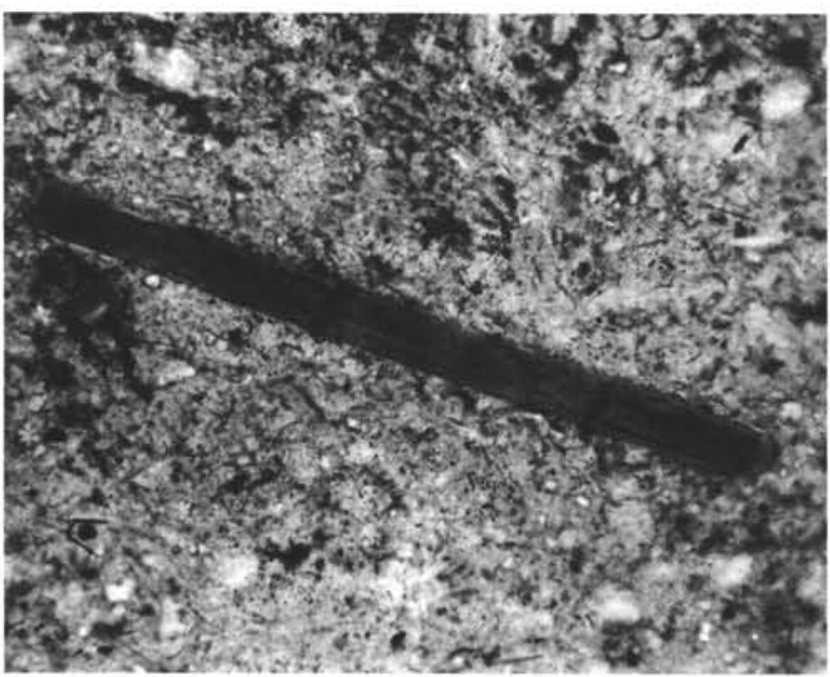

5
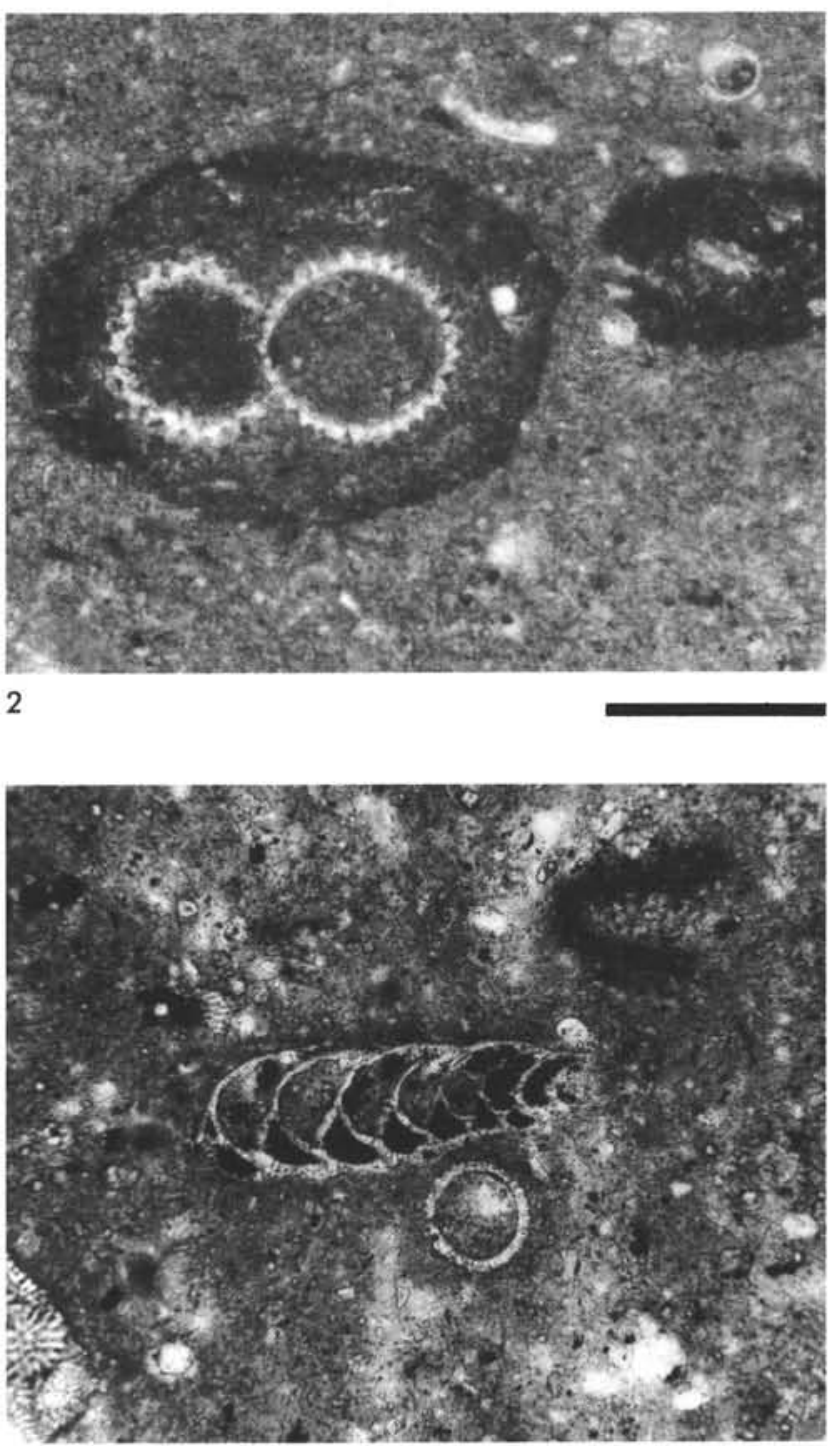

4

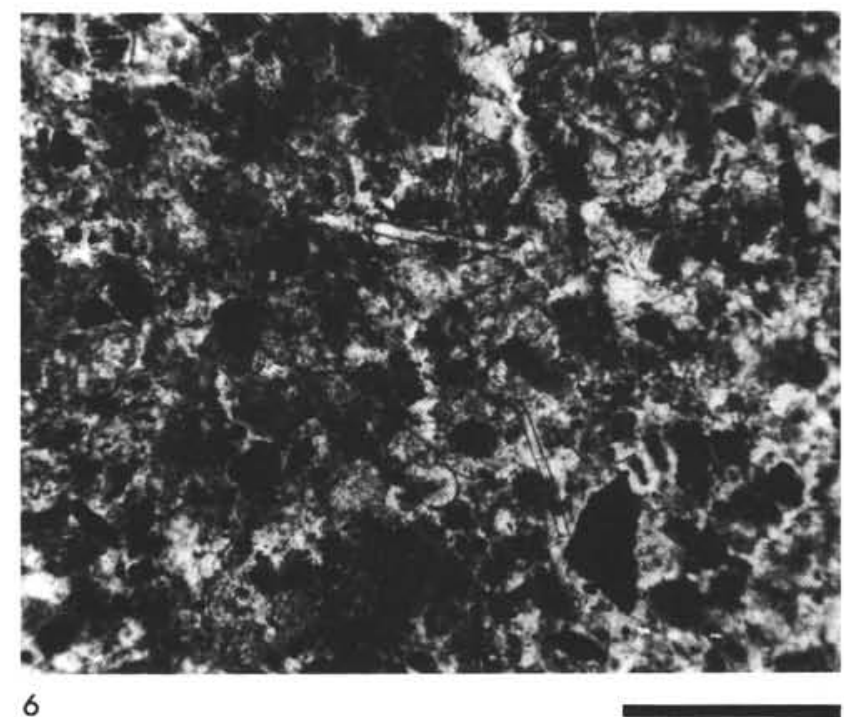


PLATE 7

Diagenetic features of Cenozoic sediments, Leg 27.

Figure 1 Sample 259-6-3, 74-76 cm. Secondary clinoptilolite filling spumellarian radiolarian mold. Sediment is stiff, pale yellowish-orange zeolite-bearing nanno ooze. Plane-polarized light. Scale bar = $100 \mu$.

Figure 2 Sample 262-45-6, 56-68 cm. Sparry calcite needles have grown radially out from septa in foraminifer into chamber. Sediment is semilithified, greenishgray foram-rich dolomitic limestone. Planepolarized light. Scale bar $=250 \mu$.

Figure 3 Sample 262-45-6, 56-58 cm. Enlarged view of 2 (above) showing sparry calcite projecting from foraminifer septa into chamber. Plane-polarized light. Scale bar $=100 \mu$.

Figure 4 Sample 262-45-6, 56-58 cm. Needles of sparry calcite that have grown from wall of foraminifer into chamber. Plane-polarized light. Scale bar = $100 \mu$.

Figure 5 Sample 262-21-1, 99-101 cm. Chambers of foraminifer completely filled with pyrite. Perforations in foram wall also filled with pyrite. Sediment is stiff, grayish-olive, foram-bearing quartz and clayrich nanno ooze. Plane-polarized light. Scale bar $=250 \mu$.

Figure 6 Sample 262-22-3, 74-76 cm. Planktonic foraminifers "floating" in secondary pyrite nodule. The pyrite has partially replaced foraminifers, and completely replaced all other original sediment. Host sediment is stiff, grayish-olive, foram- and clay-rich nanno ooze. Plane-polarized light. Scale bar $=250 \mu$. 
PLATE 7
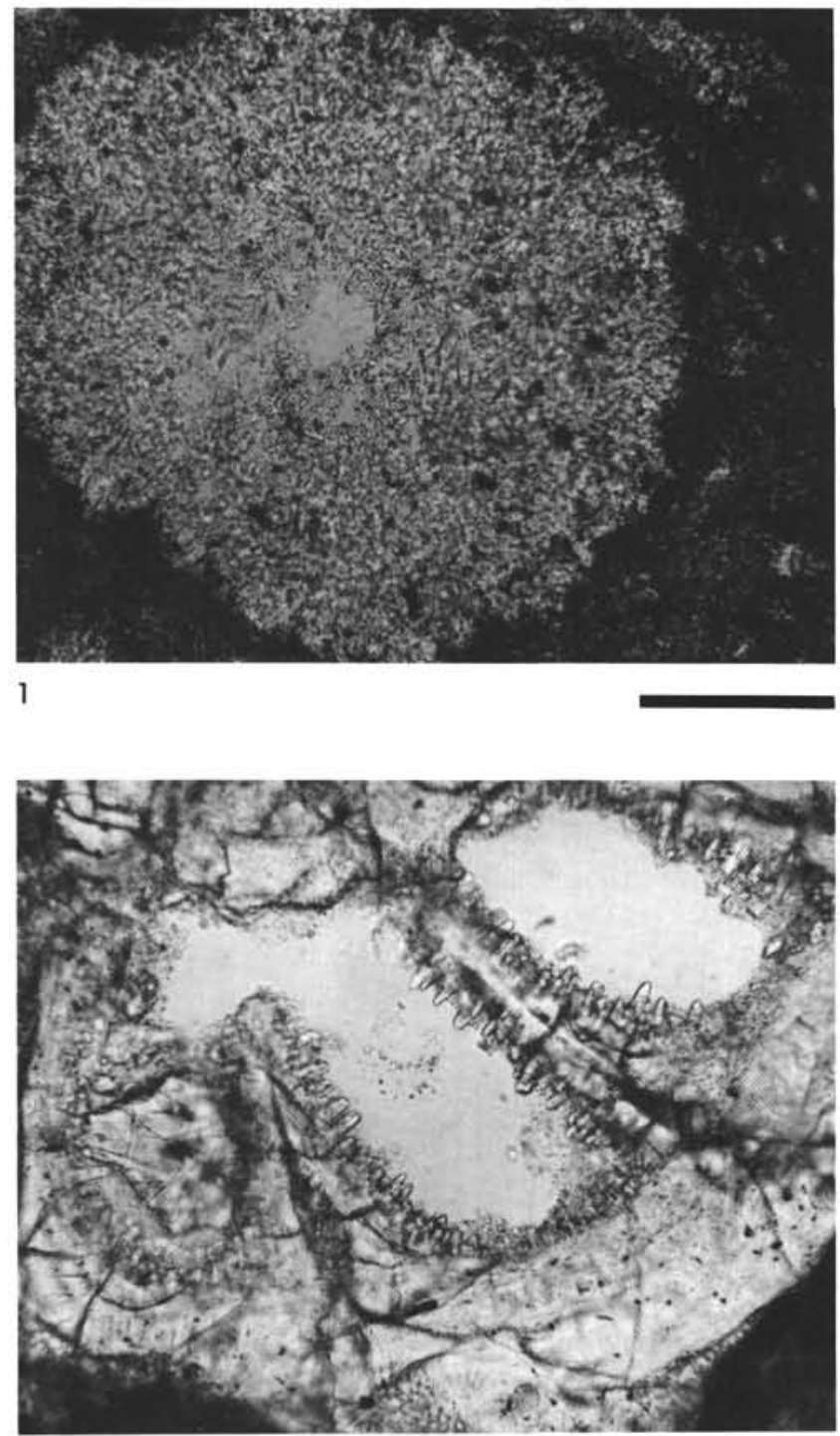

3

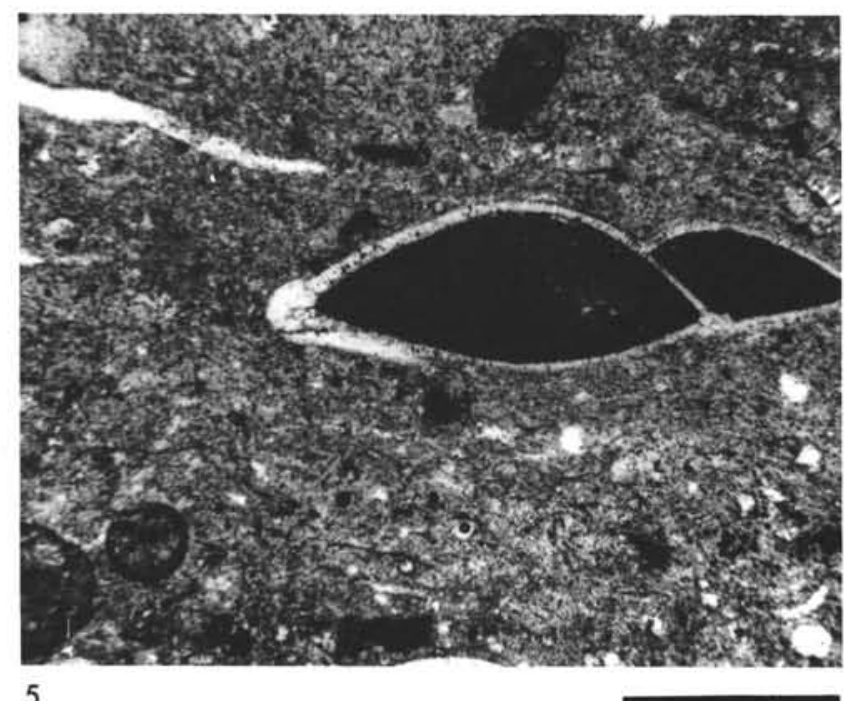

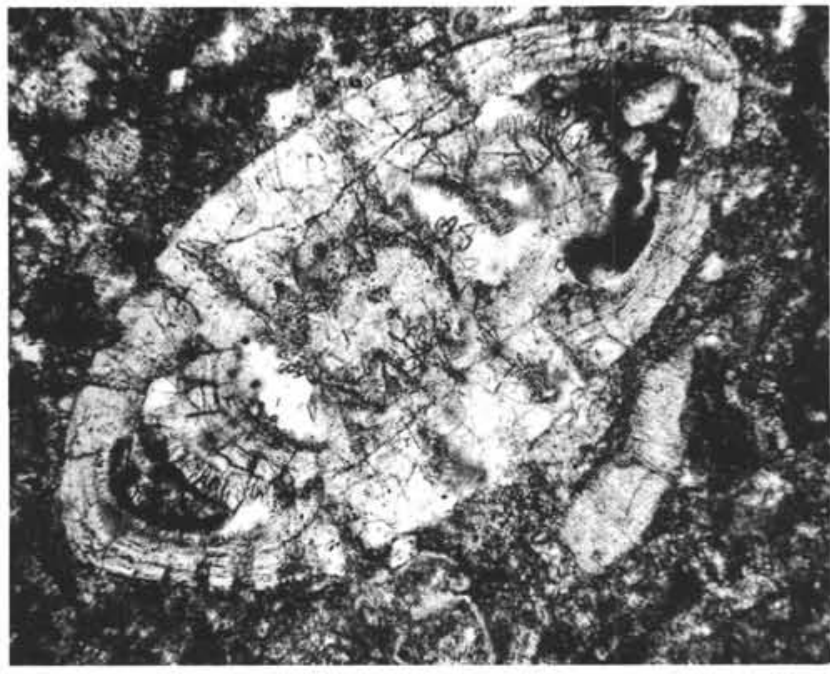

2
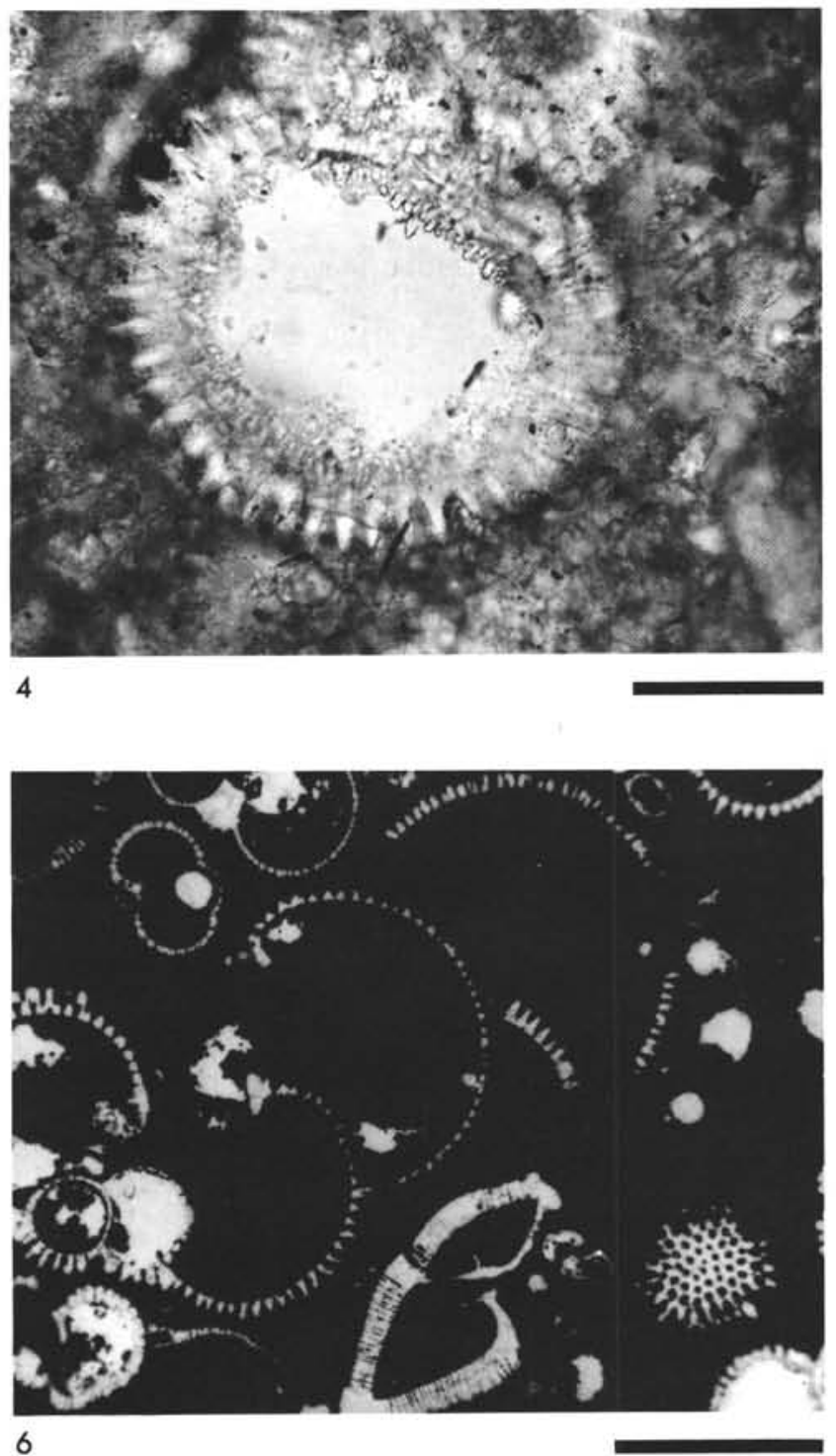


\section{PLATE 8}

Photomicrographs of Cenozoic sediments, Leg 27.

Figure 1 Sample 262-41-3, 89-91 cm. Semilithified, grayisholive micarb and nanno-rich foram ooze. Note cross-section of echinoid spine in center of field. Plane-polarized light. Scale bar $=250 \mu$.

Figure 2 Sample 262-39-3, 130-132 cm. Semilithified, grayish-green, dolomite-bearing nanno foram ooze. Note euhedral dolomite crystals which are believed to be secondary. Foraminifers are broken and set in a nannoplankton matrix. Planepolarized light. Scale bar $=100 \mu$.

Figure 3 Sample 262-45-1, 130-134 cm. Rounded molluscan allochem that has been bored by endolithic algae and fungi, and most of the bores subsequently filled with micrite. Plane-polarized light. Scale bar $=100 \mu$.

Figure 4 Sample 262-41-3, 89-91 cm. Molluscan allochem in semilithified, grayish-olive, micarb and nannorich foram ooze. Plane-polarized light. Scale bar = $250 \mu$.

Figure 5 Sample 262-46, CC. Rounded coralline algae fragment that has been bored by endolithic algae and fungi and partially micritized and pyritized. Rock is a light greenish-gray, dolomitic shell calcarenite. Plane-polarized light. Scale bar $=100 \mu$.

Figure 6 Sample 262-45-1, 130-134 cm. Echinoderm grain (E) with syntaxial calcite rim. Rock is pale olive molluscan and echinoderm-bearing, foram-rich dolomitic limestone. Plane-polarized light. Scale bar $=100 \mu$. 
PLATE 8
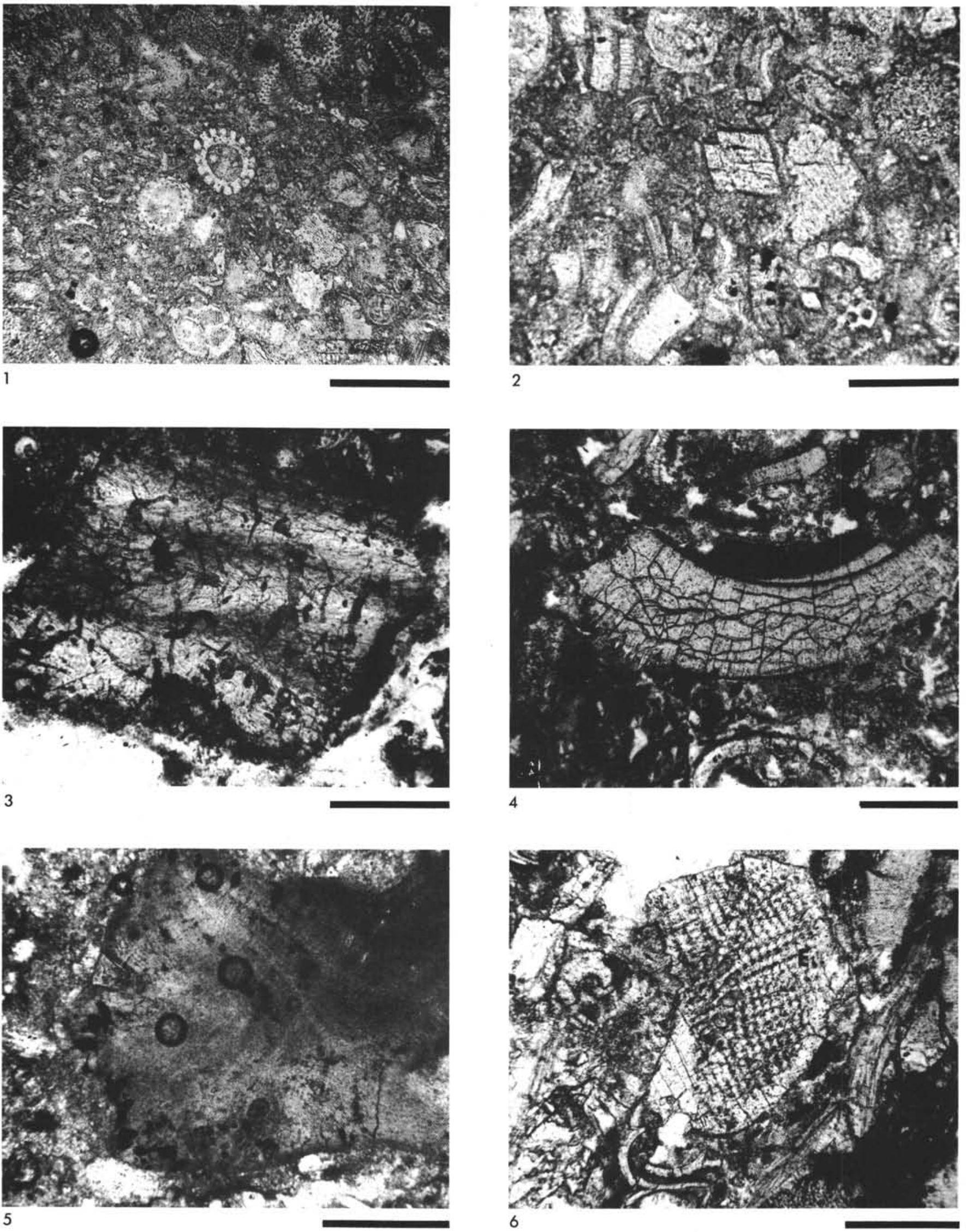


\section{PLATE 9}

Scanning electron micrographs of Cenozoic and Mesozoic sediments, Leg 27.

Figure 1 Sample 262-45-6, $6 \mathrm{~cm}$ (Pliocene). Dolomite rhombs in foram-rich dolomitic limestone.

Figure 2 Sample 259-17-4, 29-31 cm (Lower Cretaceous). Cluster of tabular and blocky clinoptilolite crystals in semilithified zeolite clay.

Figure 3 Sample 263-24-4, 143-148 cm (Lower Cretaceous). Cluster of curving vermicular kaolinite crystals in quartz-rich silty claystone.

Figure 4 Sample 259-17-4, 29-31 cm (Lower Cretaceous). Aggregate of twinned clinoptilolite crystals in zeolite clay.

Figure $5 \quad$ Sample 259-17-4, 29-31 cm (Lower Cretaceous). Cluster of twinned clinoptilolite crystals in zeolite clay. 


\section{PLATE 9}
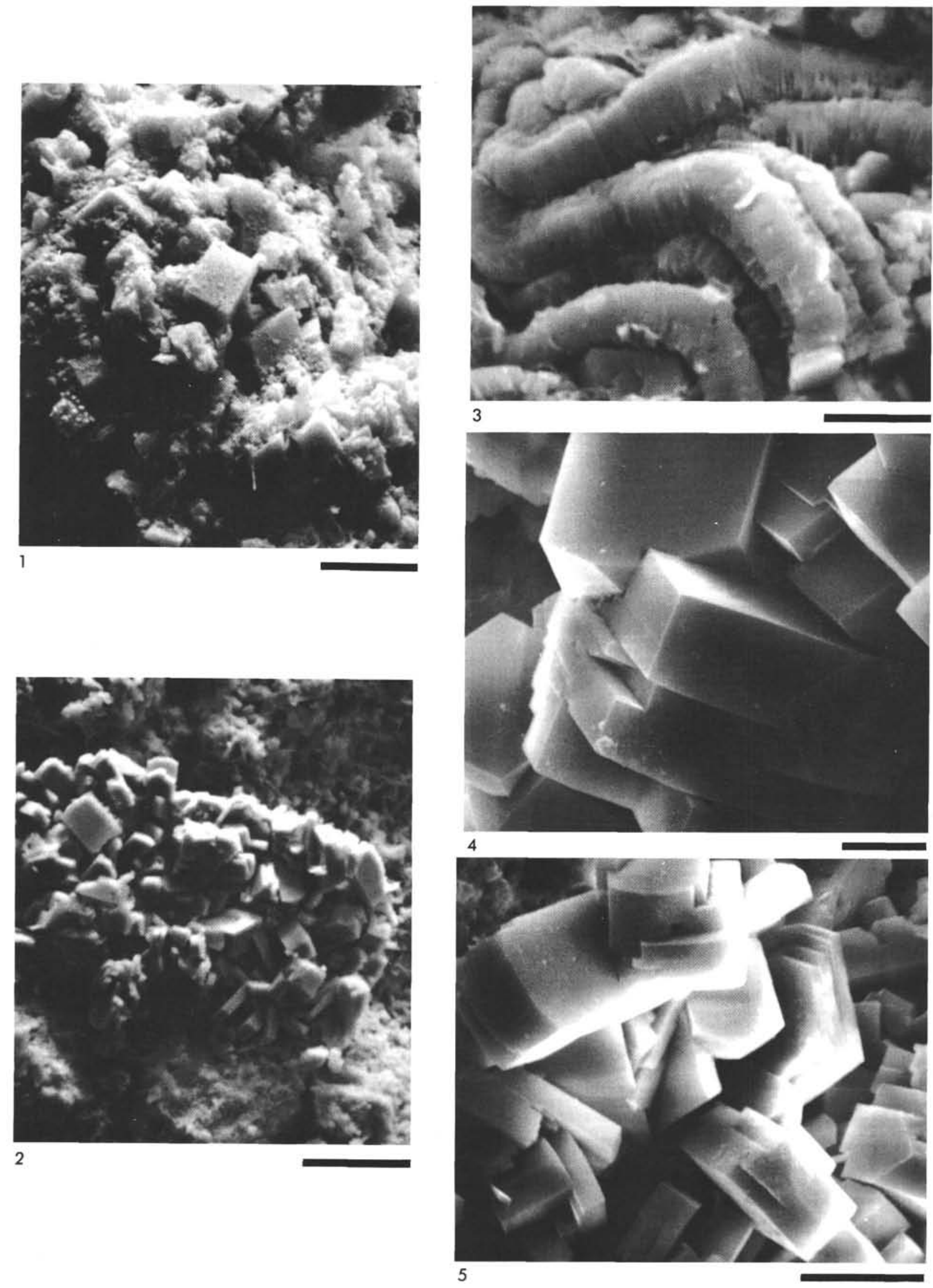
Figure 1 Sample 261-26-2, 80-94 cm (Cretaceous). Distinct mottles and thin, irregular layers of light gray carbonate in dark gray, fissile quartz claystone. Note also very thin, black, regular horizontal laminae. Horizontal cracks due to core handling.

Figure 2 Sample 260-8-6, 75-93.6 cm (Albian). Slightly disturbed, thin bedded, moderate brown zeoliterich clay alternating with yellow-brown thin bed of zeolite-rich clay in center. Upper brown silty clay contains thin, regular layers of yellow-brown zeolite-rich clay.

Figure 3 Sample 261-23-1, 35-51 cm (Upper Cretaceous). Semilithified, dark gray, silty, quartz claystone. Dark, regular and irregular, organic-enriched color laminae are both inclined and horizontal. Distinct color mottles are also present. Crack in center due to core recovery. Regular inclined striations in upper-third are sawmarks.

Figure 4 Sample 261-25-2, 53-65 cm (Cretaceous). Dark gray, semilithified quartz claystone with thin, very dark gray, regular and irregular horizontal laminae. Distinct black mottles are probably burrows.

Figure 5 Sample 261-20-3, 63-73 cm (Upper Cretaceous?). Medium dark gray quartz claystone with faint, dark gray, regular horizontal laminae.

Figure 6 Sample 263-6-2, 55-67 cm (Cretaceous). Semilithified, greenish-black quartz-rich clay with thin, grayish-black, regular horizontal laminae.

Figure 7 Sample 260-15-4, 102-118 cm (Lower Cretaceous). Thin bed of dark greenish-gray, clay nanno ooze (center) between thin beds of greenishgray nanno ooze. Upper two beds possess thin, regular and irregular horizontal laminae. Middle layer also has folded-appearing laminae (center) and distinct mottles. Lower bed has faint thin laminae. Curving cracks result from core recovery.

Figure 8 Sample 263-16-1, 27-48 cm (Aptian?). Semilithified, greenish-black, quartz-rich sandy clay with regular and irregular horizontal laminae and distinct mottles of grayish-black quartz-rich clay. Horizontal cracks result from core handling.

Figure 9 Sample 259-28-3, 139-148 cm (Lower Cretaceous). Stiff, dark greenish-gray cristobalite clay with faint, indistinct yellowish-gray mottles.

Figure 10 Sample 259-14-6, 135-148 cm (late Albian). Greenish-gray cristobalite and clay-rich nanno ooze (above), and moderate yellowish-brown nanno ooze (below). Both are indistinctly mottled and deformed by drilling. Note faulted mottle in center. 
PLATE 10

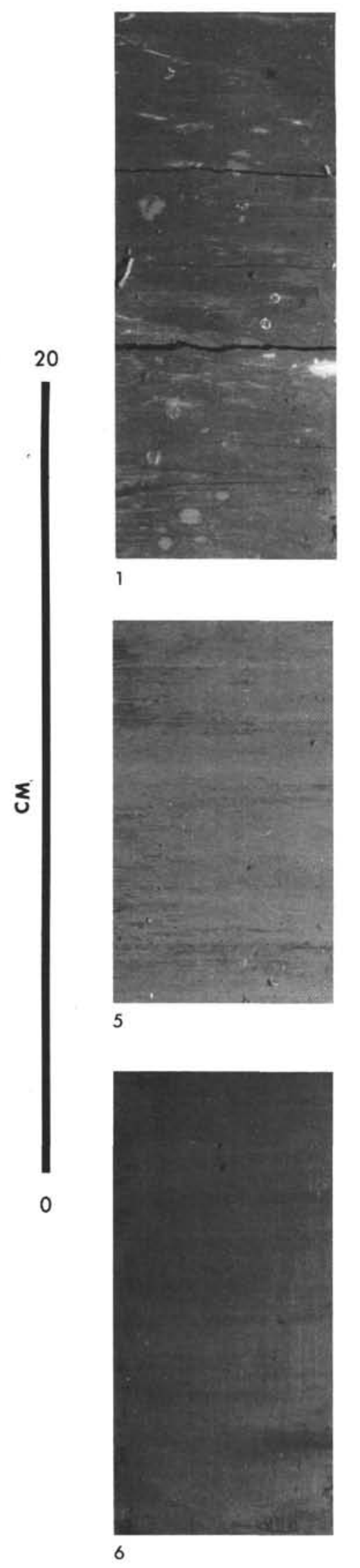

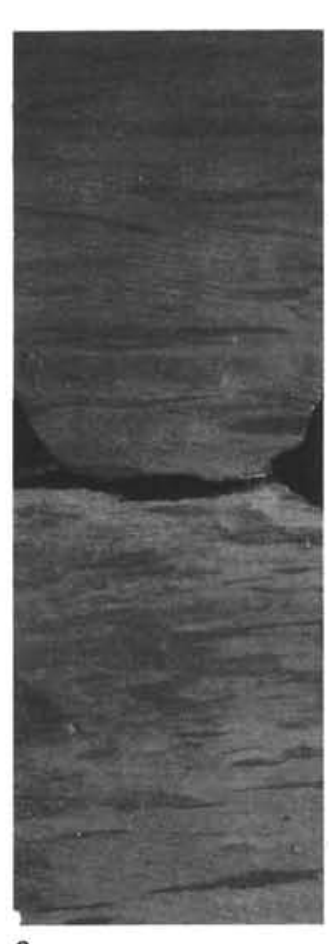

3
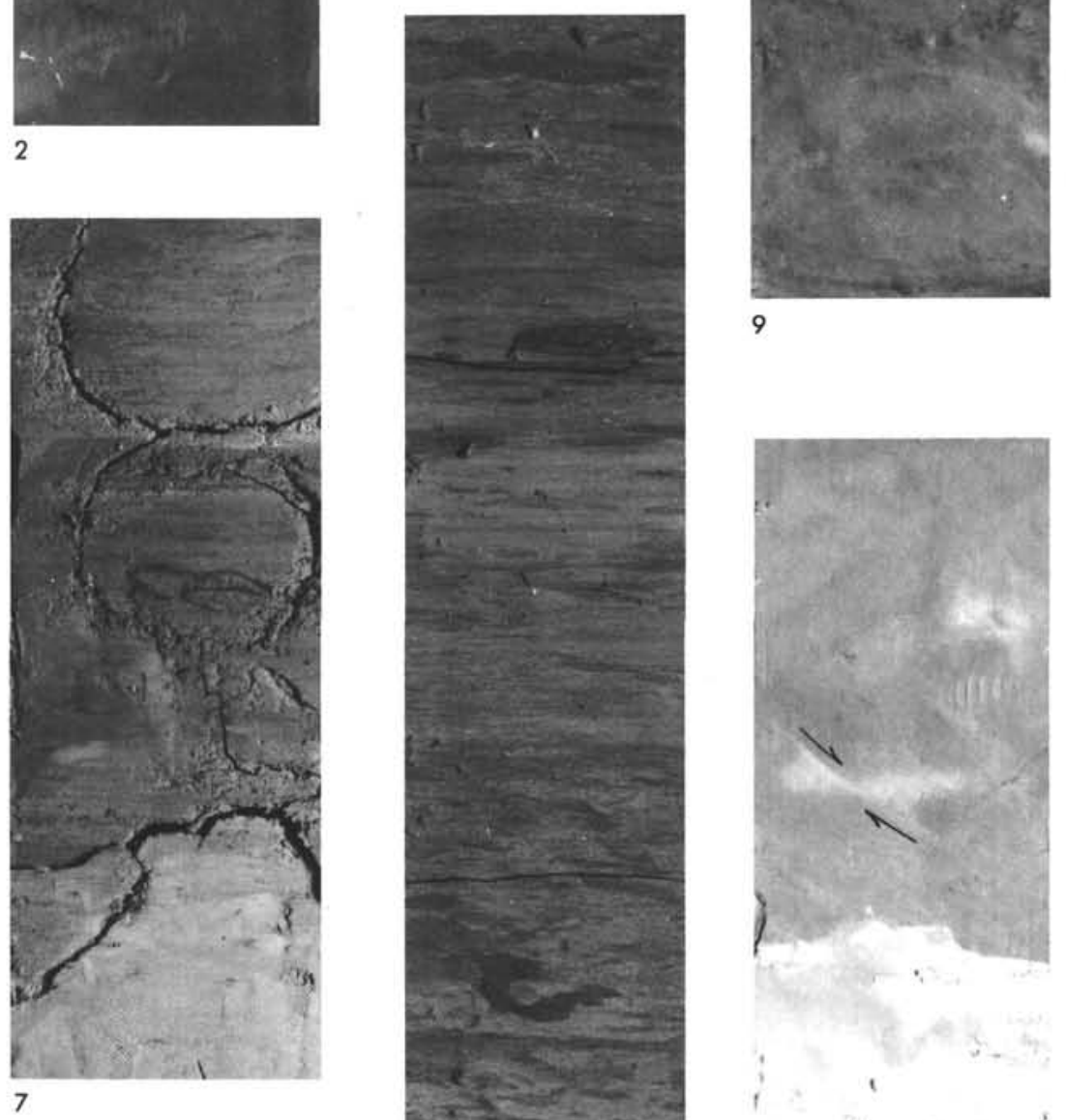

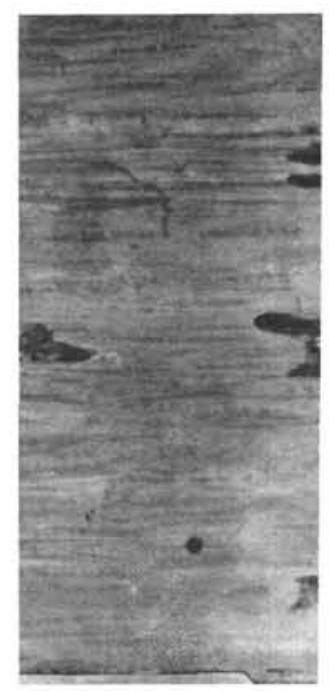

4
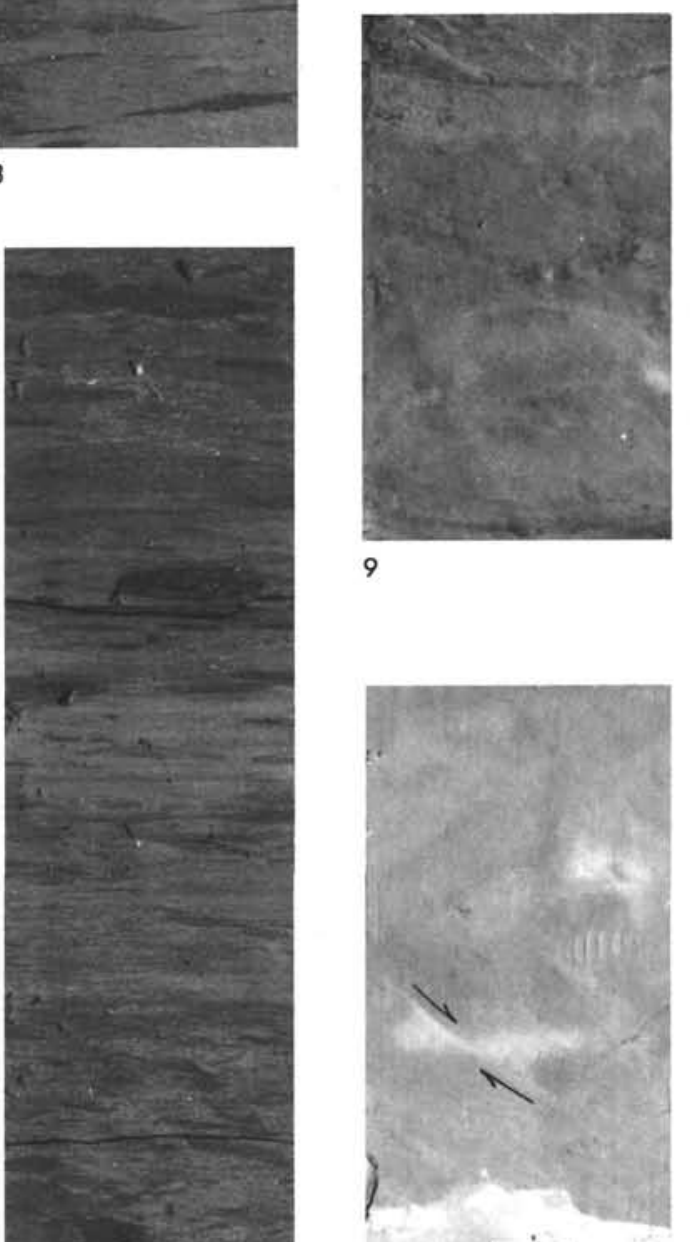

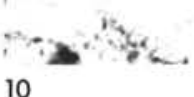




\begin{abstract}
PLATE 11
Sedimentary structures of Cretaceous sediments, Leg 27.

Figure 1 Sample 261-29-2, 0-18 cm (Lower Cretaceous). Semilithified, moderate brown quartz claystone with irregular layers and mottles of pale gray calcareous clay.
\end{abstract}

Figure 2 Sample 259-16-4, 121-138 cm (late Albian). Moderately deformed, irregularly layered and mottled, greenish-gray and light olive-brown clay and zeolite-bearing nanno ooze. Dark layers are enriched in clay.

Figure 3 Sample 260-15-4, 40-57 cm (Lower Cretaceous). Semilithified, light greenish-gray nanno ooze (middle and lower part) alternating with dark greenish-gray clay nanno ooze. Irregular color laminations are wavy and slightly inclined. Distinct light-colored mottles in darker upper and lower portions are probably burrows (B). Horizontal curving cracks are due to core recovery.

Figure 4 Sample 260-16-2, 2-25 cm (Lower Cretaceous). Irregularly laminated, semilithified greenish-gray zeolite clay. Distinct dark mottles (M) near center are probably Chondrites burrows. Tapering horizontal cracks near core margins are due to core recovery.

Figure 5 Sample 260-10-2, 4-20 cm (Lower Cretaceous, Albian). Thin bed of stiff, thinly laminated, moderate orange-pink nanno ooze (center) intercalated with silty, dark yellowish-brown, zeolite and clay-bearing nanno ooze. Upper silty layer is vaguely cross-laminated. Lower dark layer is irregularly laminated and distinctly mottled. Middle bed has regular, uniformly thick color laminations. Large cracks near margins result from core recovery. Dark specks in bottom of middle layer are marks on negative.

Figure 6 Sample 260-10-1, 82-101 cm (Lower Cretaceous, Albian). Wavy and irregularly laminated, dark yellowish-brown zeolite and clay-bearing nanno ooze. Lighter-colored laminae and mottles are moderate orange-pink nanno ooze. Rounded white areas in lower third are carbonate concretions (C). Distortions of layering and numerous fractures result from core recovery and handling.

Figure 7 Sample 263-25-4, 55-70 cm (Lower Cretaceous, Albian). Thin bed or nodule of light-colored dolomite in semilithified, olive-gray quartzbearing claystone. Darker claystone is mottled and irregularly color laminated; dolomite is faintly mottled. Large cracks result from core recovery.

Figure 8 Sample 260-10-1, 109-122 cm (Lower Cretaceous, Albian). Interbedded light brown clay and zeolitebearing nanno ooze $(\mathrm{A})$, and moderate orangepink nanno ooze (B). Both display wavy, irregular color laminations (pinch and swell). Note lightcolored distinct mottles (carbonate concretions) 
PLATE 11
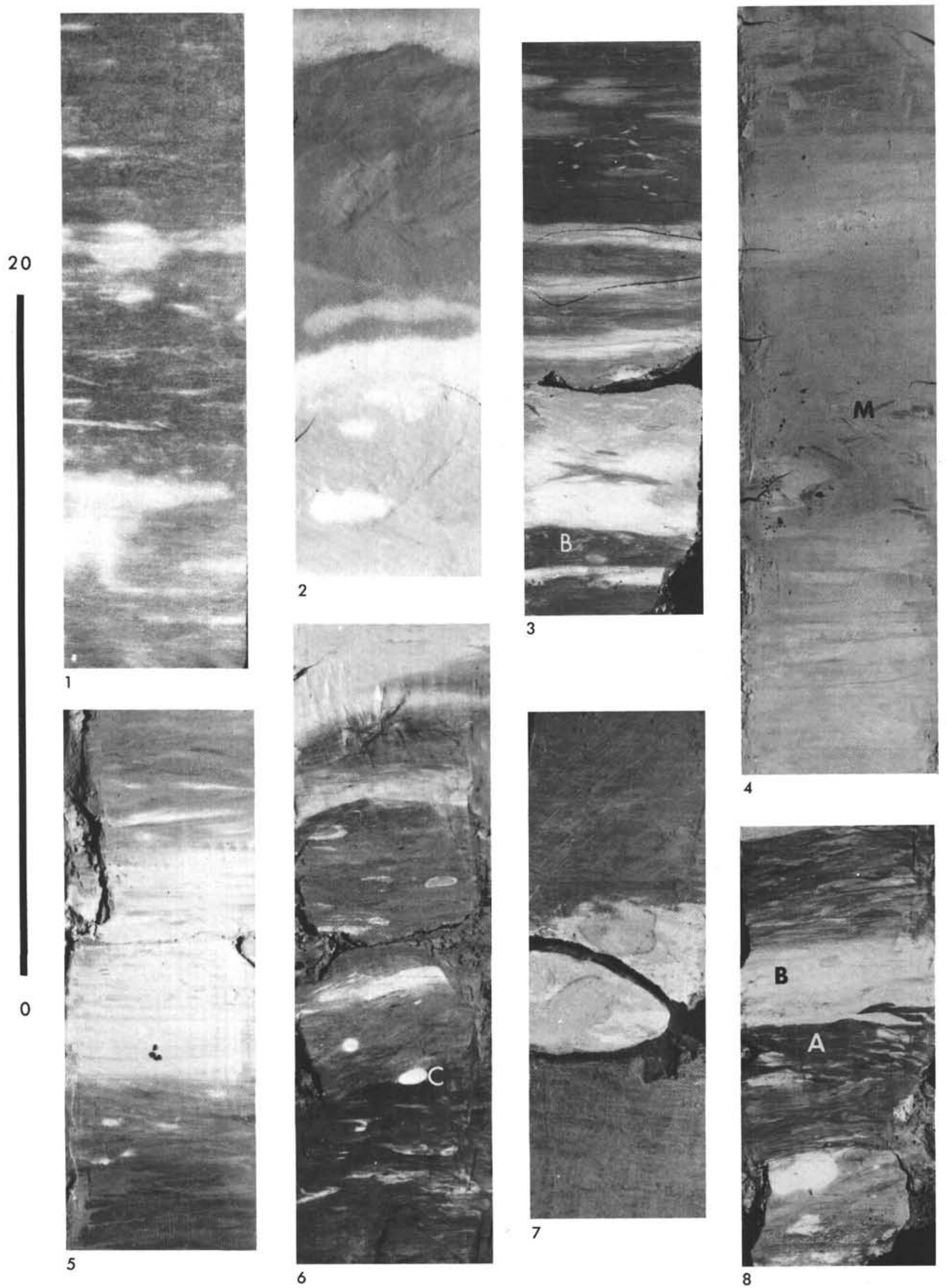
PLATE 12

Sedimentary structures of Cenozoic sediments, Leg 27.

Figure 1 Sample 262-41-3, 58-74 cm (upper Pliocene). Semilithified, pale olive, mocarb and nanno-rich foram ooze with faint, grayish-olive, irregular laminae and distinct mottles. Dark mottles near top are probably burrows (B). Pits, grooves, and fractures result from core recovery and handling.

Figure 2 Sample 262-38-3, 25-38 cm (upper Pliocene). Homogeneous-appearing, semilithified, dusky yellow-green, nanno-rich foram oozee.

Figure 3 Sample 260-3-4, 100-119 cm (middle Miocene). Vaguely color banded, grayish-orange claybearing nanno ooze. Fractures, grooves, and inclined streaks result from core recovery and handling.

Figure 4 Sample 260-4-5, 56-68 cm (Oligocene). Stiff, grayish-orange, foram-bearing nanno ooze with thin irregular laminae and distinct mottles. Laminae are bent and distorted by drilling deformation. Fractures result from core recovery.

Figure 5 Sample 262-12-4, 60-78 cm (Quaternary). Soft, greenish-gray, nanno-rich detrital foram silty sand. Homogeneous-appearing sand is graded.

Figure 6 Sample 263-1-4, 105-120 cm (Quaternary). Soft, greenish-gray quartz-rich detrital foram sand. Massively bedded, homogeneous-appearing sand is graded. Large milky white angular grains are molluscan fragments (M). Dark grains are heavy minerals and iron oxide fragments.

Figure 7 Sample 262-2-3, 26-40 cm (Quaternary). Massively bedded, stiff, grayish-olive, quartz and clay-rich nanno ooze. Cracks and small circular pits result from core handling.

Figure 8 Sample 262-36-1, 80-92 cm (upper Pliocene). Stiff, grayish-olive clay nanno ooze with broad color banding and thin, regular cross-laminae. Note also irregular horizontal laminae and distinct mottles in center. Vertical striations and pits result from core handling.

Figure 9 Sample 259-3-1, 52-62 cm (Cenozoic). Stiff, moderate yellowish-brown, zeolite silty clay with indistinct dark yellowish-orange mottles. Numerous pits result from core handling. 
PLATE 12

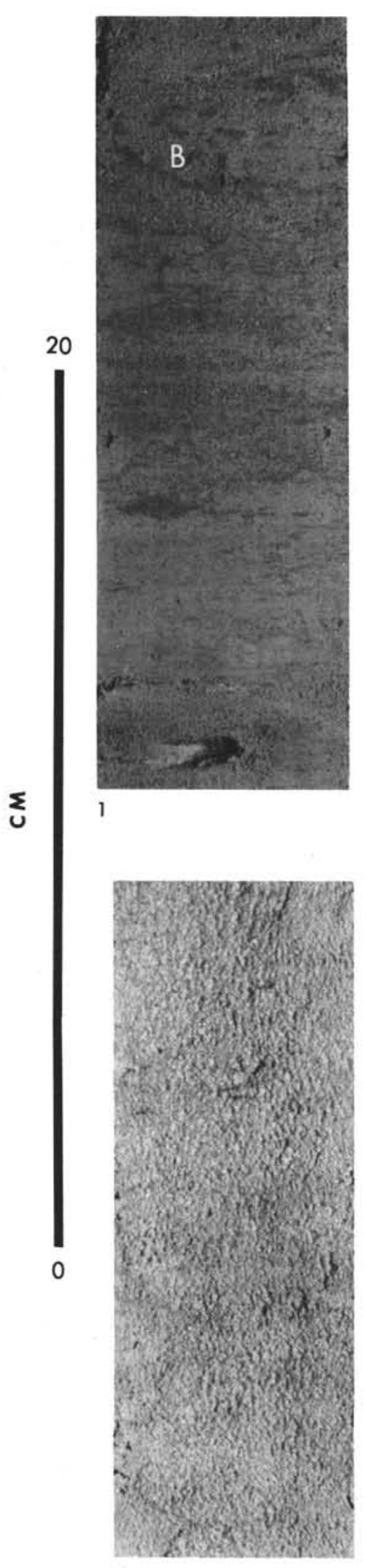

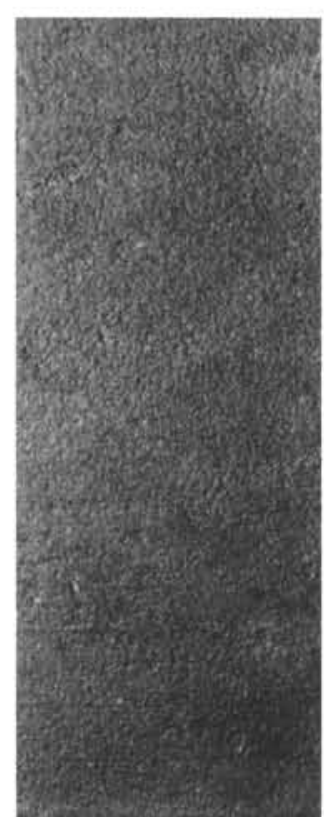

2
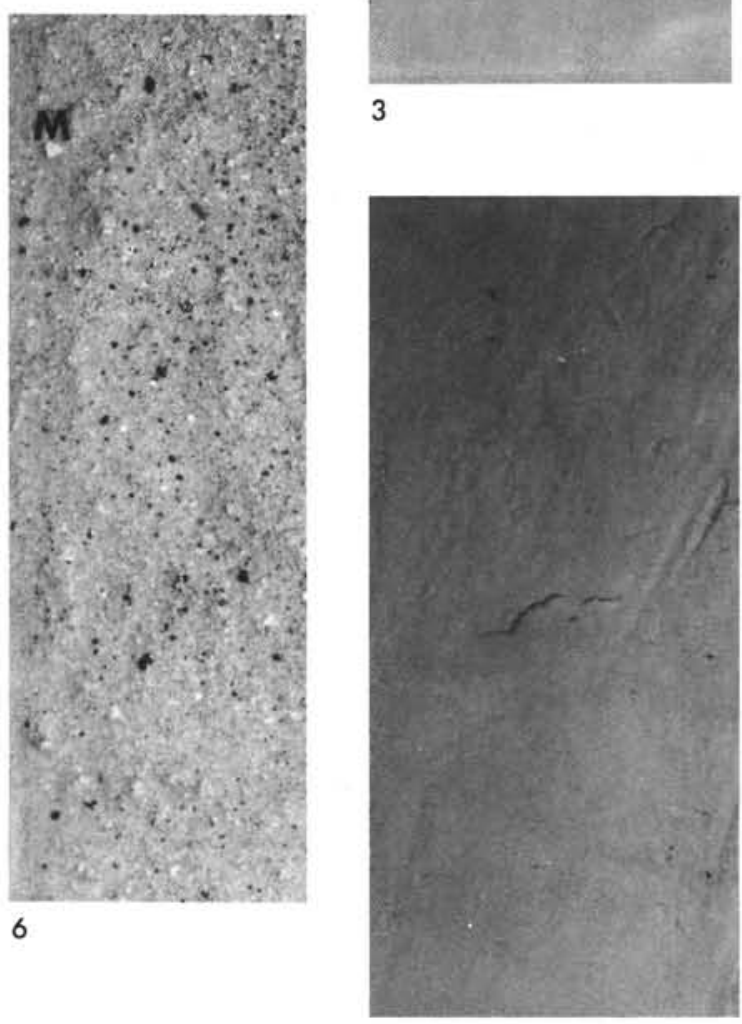

7

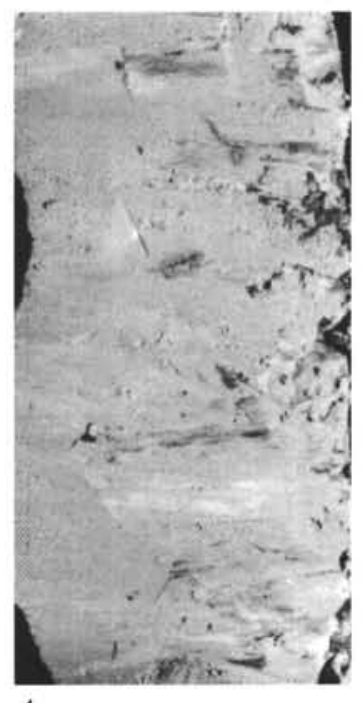

4

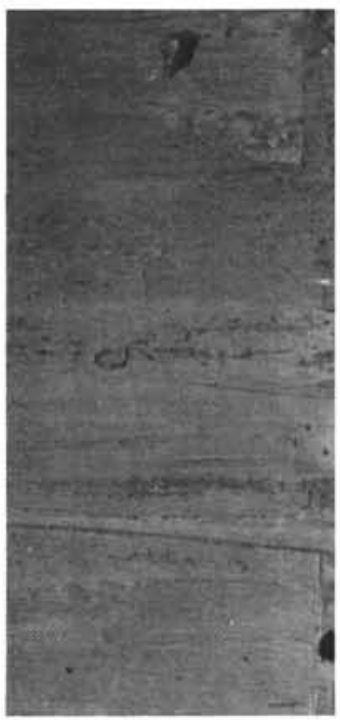

8

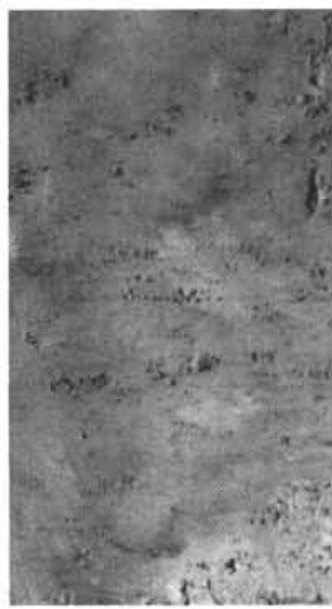

9 
PLATE 13

Sedimentary structures of Cenozoic sediments, Leg 27.

Figure 1 Sample 261-4-2, 86-124 cm (lower Pliocene-upper Miocene). Stiff, olive-gray clay overlain by graded, light gray detrital foram nanno ooze. Clay overlies very light gray rad and nanno-bearing clay. Upper and lower contacts are sharp even though disturbed by drilling. Dark clay is vaguely color banded and indistinctly mottled. Cracks, curving grooves, and pits result from core handling.

Figure 2 Sample 260-3-6, 110-125 cm (middle Miocene). Graded, very pale orange detrital foram nanno ooze overlying dusky yellowish-brown, distinctly mottled nanno clay. Irregular contact between units and mottling of nanno clay probably results from drilling deformation.

Figure 3 Sample 259-3-1, 77-97 cm (Cenozoic). Moderately mottled, yellowish-brown, stiff zeolite silty clay. Vertical alignment of distinct dark yellowishorange mottles results from drilling deformation.

Figure 4 Sample 262-24-6, 61-76 cm (Quaternary). Broadly color banded and thinly laminated, pale olive clayrich nanno chalk. Dark gray laminae are slightly inclined, suggesting cross-stratification. Small dark specks scattered uniformly across core face are pores of unknown origin. Curving grooves are sawmarks. Horizontal fractures result from core recovery.

Figure 5 Sample 262-11-6, 77-97 cm (Quaternary). Stiff, grayish-olive, rad-rich nanno ooze with faint, dark gray horizontal laminae and streaks. Dark gray areas are rich in pyrite, clay, and plant debris. Coarser laminae are foram nanno ooze (F). Fractures and pits result from core handling.

Figure 6 Sample 260-4-1, 15-31 cm (Oligocene?). Interbedded very pale orange nanno ooze (A) and grayish-orange, clay nanno ooze (B) in sharp contact with underlying yellowish-brown clay (C). Nanno ooze and clay nanno ooze display thin, irregular color laminae and slight mottles. Clay is distinctly mottled (burrowing?). Sharp contacts between units have been distorted and crumpled by drilling. Cracks and grooves result from core recovery and handling.

Figure 7 Sample 262-45-1, 75-95 cm (upper PliocenePliocene contact). Semilithified, pale grayish-olive, foram-rich micarb ooze with thin and regular, grayish-olive laminae. Sharp contact with underlying pale olive, homogeneous foram-rich dolomitic limestone marks the upper PliocenePliocene contact. Numerous cracks result from core recovery. 
PLATE 13
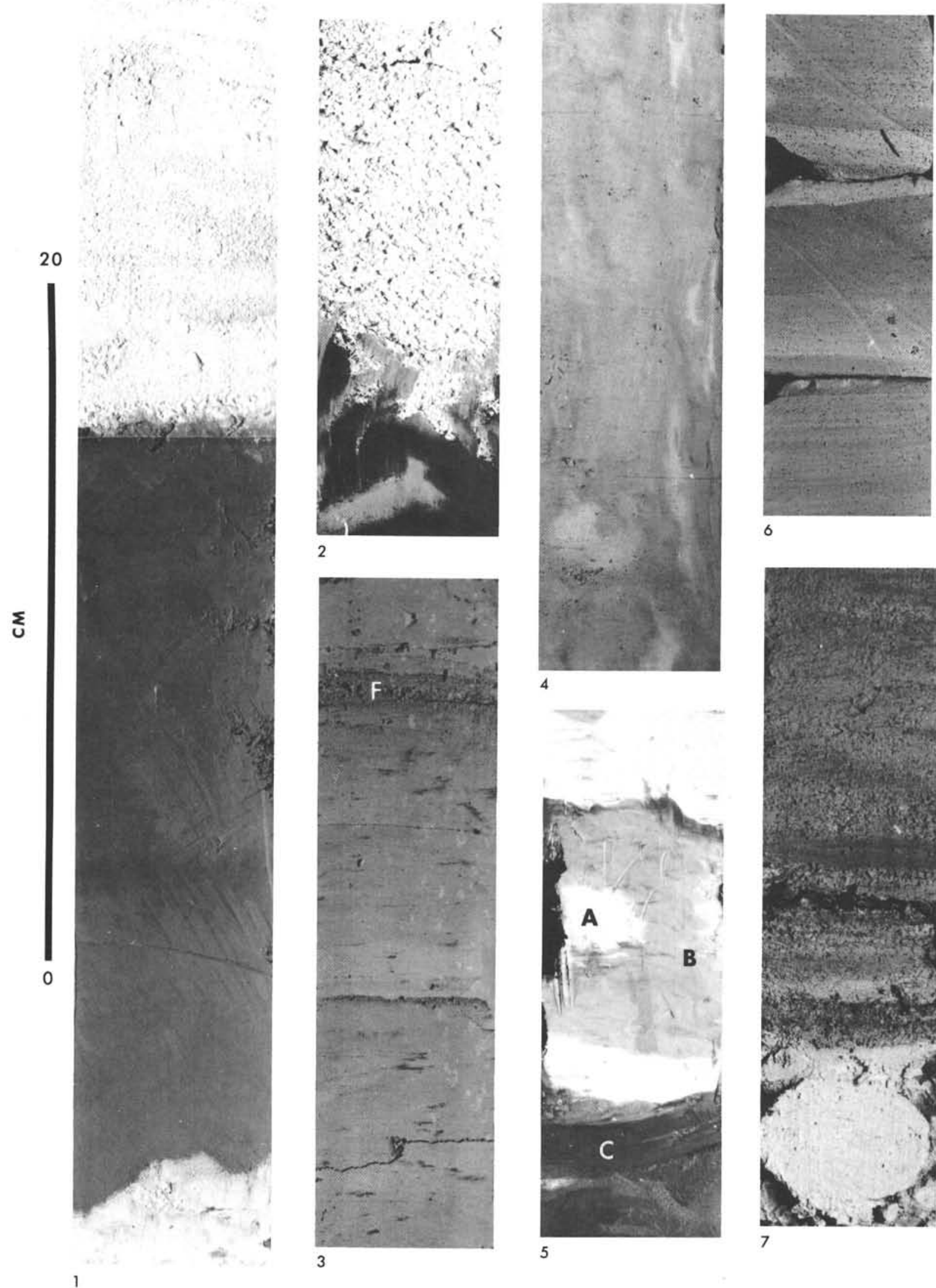

2

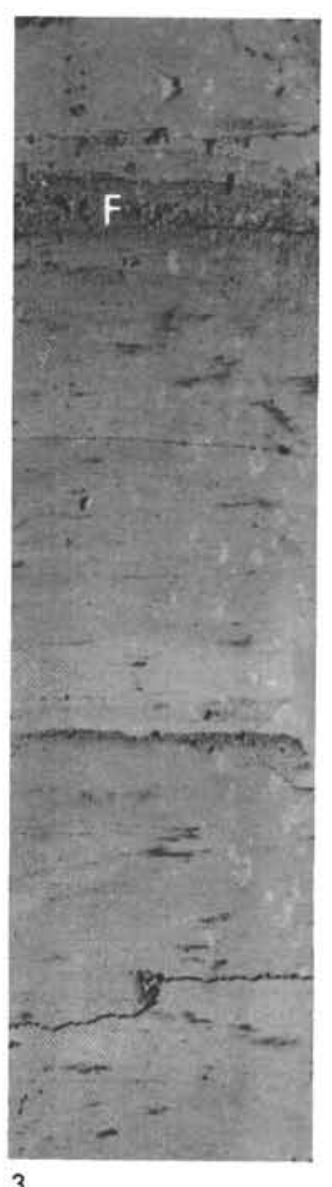

6

4
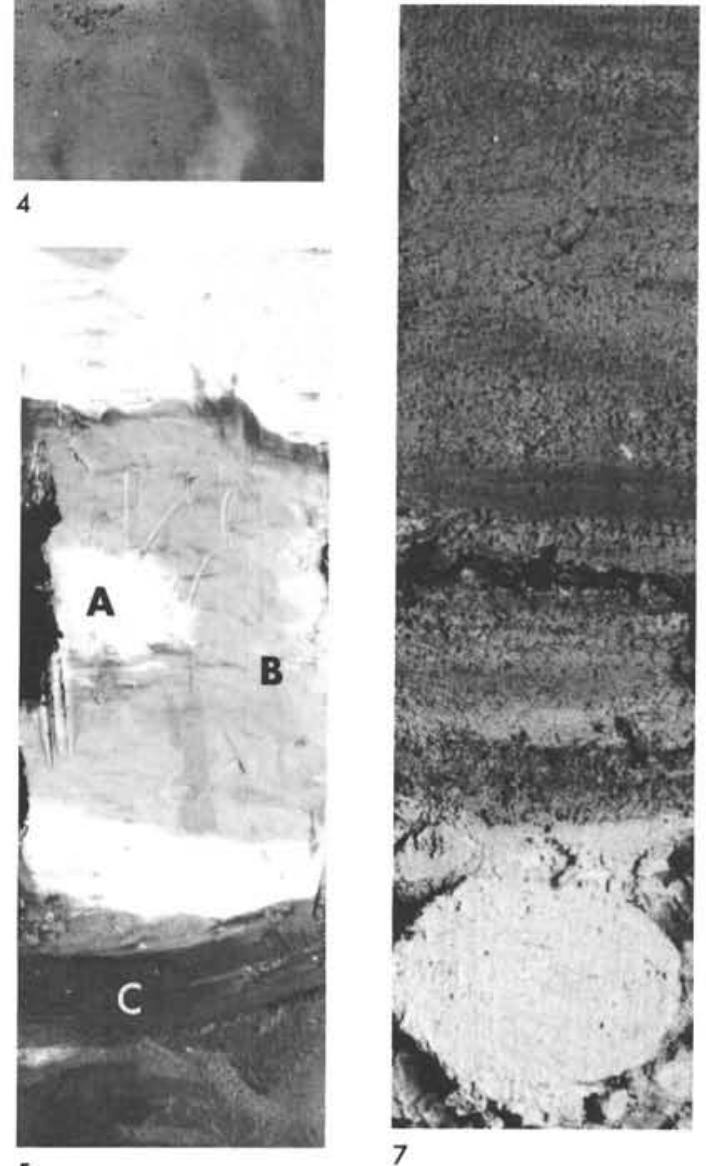